\title{
A situação do trabalho das cooperativas de catadores frente à valorização econômica da reciclagem
}

\author{
Christine Parmezani Munhoz
}

Dissertação apresentada ao Programa de Pós-Graduação em Saúde Pública da Faculdade de Saúde Pública da Universidade de São Paulo para obtenção do título de Mestre em Saúde Pública.

Área de Concentração: Saúde Ambiental Orientador: Prof. Dr. Antônio Carlos Rossin

São Paulo

2004

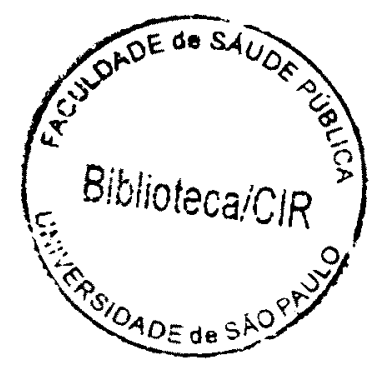




\section{Resumo}

Munhoz CP. A Situação do Trabalho nas Cooperativas de Catadores Frente à Valorização Econômica da Reciclagem. São Paulo; 2004. [Dissertação de Mestrado - Faculdade de Saúde Pública da USP].

As cooperativas de catadores de materiais recicláveis englobam duas questões atuais: a crise no emprego, com a mudança nos contratos trabalhistas e a relação do homem com o meio ambiente. Neste contexto, é crescente o número de prefeituras municipais que incluem estas cooperativas nos sistemas institucionais de limpeza urbana. Para que estas iniciativas se consolidem, é necessário identificar as principais variáveis que auxiliam e dificultam o desenvolvimento de suas atividades.

Foi realizado um estudo de caso em três cooperativas da RMGSP. Um estudo descritivo qualitativo, com coleta de dados primários, e a elaboração de indicadores que permitiu uma análise comparativa, entre as cooperativas selecionadas.

O apoio governamental e a atuação dos "mentores" destes projetos são relevantes. Entretanto, a existência de um "gargalo" no mercado de reciclagem, em que poucas indústrias conseguem determinar o preço dos recicláveis, e a necessidade de organizar as atividades de capacitação gerencial e tecnológica, dificultam a consolidação do trabalho dos catadores.

Para o desenvolvimento da coleta seletiva solidária, recomenda-se a aplicação da legislação ambiental, com políticas que mesclem instrumentos econômicos com comando e controle, incentivando a redução de resíduos antes do estímulo à reciclagem. A inclusão dos benefícios sociais, além dos benefícios privados, proporcionados pela reciclagem possibilitaria a concessão de créditos para os recicladores.

Recomenda-se pesquisas para a capacitação tecnológica do trabalho dos catadores, além de atividades que promovam uma maior integração entre as cooperativas, aumentando a autonomia em relação ao apoio dado pelo Estado.

Descritores: Catadores; Limpeza Urbana; Resíduos Domésticos; Reciclagem (Saúde Ambiental), Comportamento Cooperativo; Coleta Seletiva. 


\section{ABstract}

Munhoz CP. Solidary selective collection: The cooperative of scavengers and its relations with the recycling market, public services of urban cleaning and civil society. São Paulo; 2004. [Master Thesis - Faculdade de Saúde Pública de USP].

The cooperatives of recycling materials scavengers embody two questions: the employment crisis, with change in work contracts, and the relation between man and environment. In this context, is increasing the number of municipal councils including these cooperatives in its institutional systems of urban cleaning. To the consolidation of these initiatives, it is needed to identify the main variables that help and difficult the development of its activities.

A case study was realised in three of RMGSP cooperatives. A qualitative descriptive study, with primary data collection, and the elaboration of indicators allowed a comparative analysis among the selected cooperatives.

The governmental backing and the action of the "mentors" of these projects are relevant. However, the existence of a "bottleneck" in the recycling market, where a few industries manage to determine the price of recyclable materials, and the need to organize the capacitation activities, managerial and technological, make the consolidation of scavengers work difficult.

For an development of solidary selective collection, it is recommended the application of the environmental legislation, where politics mix economics instruments with command and control, encouraging the residue reduction before the stimulus for recycling. The inclusion of social benefits, beyond the private ones, provided through recycling would enable the credit concession for the recycling.

It is necessary the sectorial analysis of the different recycling markets and the definition of the possible juridical contracts between the public power and cooperatives to direct the capacitation activities to be developed.

Descriptors: Scavengers, Urban Cleaning, Domestic Residues, Recycling (Environment Health), Cooperative Behaviour, Solidary Selective. 


\section{LISTA DE TABELAS}

Tabela 1 - Índice de reciclagem sobre o total produzido no Brasil, por tipo de material, em porcentagem, 2002

Tabela 2 - Número de Catadores e Cálculo da Média Mensal de Catadores, em cada cooperativa analisada, 2004.

Tabela 3 - Média Mensal de Material Comercializado, por catador, Janeiro a Junho de 2004

Tabela 4 - Receita Arrecadada por Mês e Média Mensal, em cada cooperativa analisada, em Reais, 2004.

Tabela 5 - Percentual das Despesas sobre a Receita, nas cooperativas analisadas, Janeiro a Junho de 2004.

Tabela 6 - Despesas Realizadas pelo Projeto Vira Lata e Percentual dos gastos realizados com os veículos e na coleta pelo Projeto Vira Lata, 2004.

Tabela 7 - Valor da Retirada, por hora trabalhada, para cada catador, e média mensal, nas cooperativas analisadas, 2004.

Tabela 8 - Composição do Material Total Comercializado, em porcentagem, por cooperativa analisada, janeiro a junho de 2004. 107

Tabela 9 - Preço Médio de Venda, por Quilo e Tipo de Material, em cada cooperativa analisada, janeiro a junho de 2004. 108

Tabela 10 - Destinação das sobras financeiras, em cada cooperativa analisada, em Reais, 2004. 


\section{LISTA DE QUADROS}

Quadro 1 - Formação, infra-estrutura e origem dos recursos das cooperativas analisadas, de janeiro a junho de 2004.

Quadro 2 - Coordenação do trabalho nas cooperativas de catadores analisadas, de janeiro a junho de 2004.

Quadro 3 - Apoio gerencial externo nas cooperativas de catadores analisadas, de janeiro a junho de 2004.

Quadro 4 - Atividades realizadas para estimular a participação da sociedade civil no trabalho dos catadores, de janeiro a junho de 2004..102

\section{LISTA DE GRÁFICOS}

Gráfico 1 - Percentual dos Municípios, por existência da cobrança dos serviços de limpeza urbana - Brasil, 2000. 


\section{LISTA DE ABREVIATURAS}

ABAL - Associação Brasileira de Alumínio

ALBRÁs - Alumínio Brasileiro S/A

ALCAN - Aluminium Limited of Canadá

ALCOA - Aluminium Company of America

ALUMAR - Consórcio Alumínio do Maranhão

BNDES - Banco Nacional do Desenvolvimento Econômico e Social

CBA - Companhia Brasileira de Alumínio

CEMPRE - Compromisso Empresarial para a Reciclagem

CETESB - Companhia de Tecnologia em Saneamento Ambiental

CVRD - Companhia Vale do Rio Doce

Elquisa - Eletro Química Brasileira S/A

Embrapa - Empresa Brasileira de Pesquisa Agropecuária

ESALQ - Escola Superior de Agricultura "Luiz de Queiroz"

FATES - Fundo de Assistência Técnica, Educacional e Social

IBGE - Instituto Brasileiro de Geografia e Estatística

INSS - Instituto Nacional do Seguro Social

IPI - Imposto sobre Produtos Industrializados

IPT - Instituto de Pesquisas Tecnológicas

IPTU - Imposto Predial e Territorial Urbano

IQR - Índice de Qualidade em Aterros

ISO - International Standard Organization

LDO - Lei de Diretrizes Orçamentárias

NAAC - Nippon Amazon Aluminium Co. Ltda.

OIT - Organização Internacional do Trabalho

PEV's - Postos de Entrega Voluntária

PREALC - Programa Regional do Emprego para a América Latina e o Caribe

SEBRAE - Serviço de Apoio às Micro e Pequenas Empresas

TAC - Termo de Ajuste de Conduta

UNICEF - The United Nations Children's Fund 


\section{Índice}

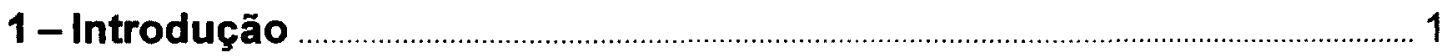

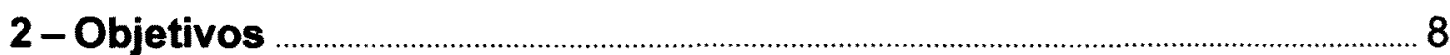

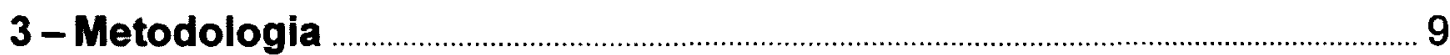

4 - Revisão Bibliográfica

4.1. O Trabalho autônomo dos catadores no setor informal da reciclagem .................................................................................................................... 12

4.1.1 Setor Informal: mudanças histórico-conceituais. .............................12

4.1.2 Composição do setor informal e características das atividades

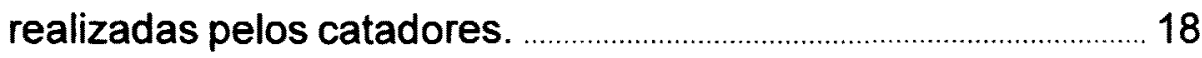

4.1.3 Espaço de atuação das atividades informais. .................................. 21

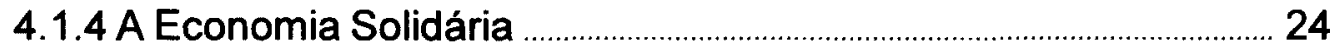

4.1.5 As cooperativas de catadores de materiais recicláveis. .............. 27

4.2. A incorporação da reciclagem pelas indústrias …………................................. 33

4.2.1 Estrutura do mercado informal de reciclagem, no Brasil .............. 38

4.2.2 A indústria de alumínio no Brasil............................................... 40

4.2.3 A indústria de papel no Brasil. ............................................................ 47

4.2.4 A reciclagem como estratégia de redução de custos. .................. 54

4.3. Bens Ambientais e Resíduos Sólidos Urbanos.................................................. 56

4.3.1 Bem público e custos sociais da degradação ambiental............... 56

4.3.2 A incorporação dos custos sociais para os resíduos sólidos

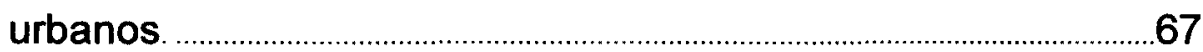

4.3.3 A inclusão das cooperativas de catadores pelo incentivo à reciclagem.

\section{5 - Estudos de Caso.}

5.1 Cooperativas de Catadores de Materiais Recicláveis na Região

Metropolitana de São Paulo.

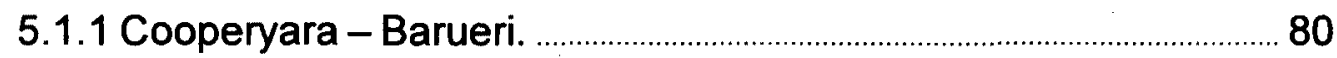

5.1.2 Associação Raio de Luz - São Bernardo do Campo. ...................... 85 
5.1.3 Projeto Vira Lata - São Paulo. ................................................................. 88

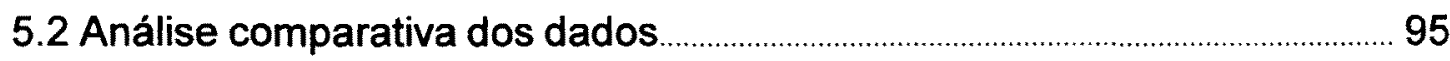

5.2.1 Formação e Infra-estrutura das cooperativas analisadas. ............95

5.2.2 Estrutura administrativa das cooperativas analisadas .................. 98

5.2.3 Aspectos Financeiros ......................................................................... 102

5.2.4 Inserção no mercado de reciclagem. .................................................. 107

5.2.5 Cumprimento das normas cooperativistas. .................................... 108

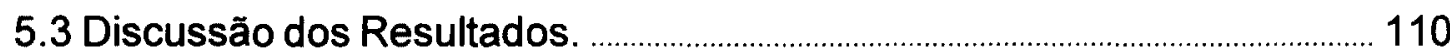

5.3.1 O apoio operacional na coleta dos materiais recicláveis ........... 110

5.3.2 O apoio na organização e consolidação do trabalho

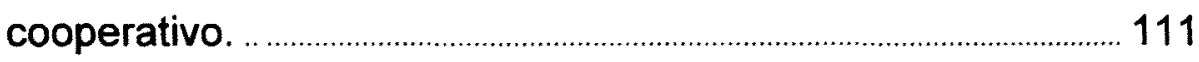

5.3.3 A participação da sociedade civil .................................................... 113

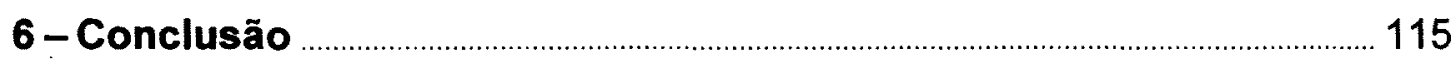

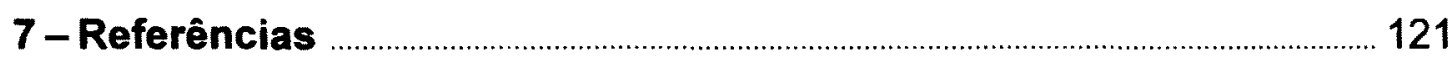

Anexos

A. Dados coletados na pesquisa de campo …….................... A 1

B. Questionário aplicado na pesquisa de campo …….................. B 1 


\subsubsection{Cooperyara - Barueri}

As atividades da Cooperyara - Cooperativa de Trabalho dos Profissionais de Reciclagem de Lixo do Município de Barueri e Região tiveram início em abril de 2002, por iniciativa da Secretaria Municipal de Recursos Naturais e Meio Ambiente, através de uma política pública municipal para retirar os catadores do antigo lixão.

Em 1999, este lixão foi avaliado pela CETESB e recebeu a nota de 1,5 pelo índice de Qualidade em Aterros - $I Q R^{12}$. Apesar de ter ocorrido melhorias, em 2003, este índice estava em 3,6, o que evidenciava, ainda, condiçöes inadequadas para o destino final de resíduos sólidos urbanos em Barueri. Pela avaliação da CETESB, para que as condiçōes sejam consideradas como controladas este índice deve estar entre 6,0 e 8,0. Para serem consideradas adequadas deve estar acima de 8,0.

Atualmente está em andamento, no município de Barueri, o TAC Termo de Ajuste de Conduta, firmado entre a CETESB e a prefeitura com o intuito de promover melhorias na operação do aterro (CETESB, 2003).

Com isto, a denominação do lixão foi modificada para aterro emergencial, pois as camadas inferiores ainda continuam poluindo o meio ambiente, mas 0 aterro recebeu uma camada impermeabilizante e para as camadas superiores já é realizada a drenagem do chorume. A administração do aterro é feita pela prefeitura, através da Secretaria de Serviços Municipais.

Em 2000, foi dado o início da retirada das crianças e das mulheres que trabalhavam no lixão, que não era nem cercado. Nesta época a Secretaria Municipal do Meio Ambiente, que foi criada apenas em janeiro de 2001, ainda era um departamento ligado à Secretaria Municipal de Habitação.

\footnotetext{
${ }^{12} \mathrm{IQR}$ - Índice de Qualidade em Aterros, índice criado pela CETESB, que reúne informaçð̋es através de inspeçaes nos locais de destinação final dos resíduos. Estas informaçōes são coletadas por um questionário padronizados, que visa identificar as características locacionais, estruturais e operacionais de cada instalação.
} 
Algumas destas cooperativas conseguem adquirir maquinários, como balanças e prensas, utilizados para o beneficiamento dos materiais recicláveis. Este maquinário, antes inacessivel ao catador individual, permite incluir atividades que antes eram executadas pelos intermediários e sucateiros, possibilitando agregar valor ao material comercializado pela cooperativa.

As iniciativas de formação de cooperativas podem ter origem entre os próprios catadores, podem ser estimuladas por organizaçōes da sociedade civil, como associações de moradores de bairros e igrejas e podem ser induzidas pelas prefeituras, que procuram incluir os catadores nos programas municipais de coleta seletiva de lixo. Quando induzidas pelas prefeituras, estas cooperativas recebem a doaçăo dos materiais recicláveis utilizados.

As cooperativas de catadores são iniciativas populares de economia solidária. $O$ objetivo principal desta organização dos catadores é gerar trabalho e renda para um setor marginalizado da populaçăo.

No entanto, a formaçăo destas cooperativas não muda a inserção frágil destes trabalhadores no mercado informal de reciclagem.

Os catadores săo auto-empregados com baixa qualificação e por isso săo obrigados a realizar ocupaçőes que exigem pouco capital e pequena escala de produçăo, com quase nenhum capital técnico ou humano, com processos tecnológicos simples, nos quais, normalmente, a tecnologia é adaptada. Além disso, estas atividades possuem utilização intensiva de trabalho, são realizadas em setores da produção onde ocorre facilidade de entrada por outros concorrentes, ou seja, num mercado competitivo e não regulado (CACCIAMALI, 1991; KON, 2001; PAMPLONA, 2001a).

Devido a estas características, mesmo ao se organizarem em cooperativas, os catadores encontram dificuldades em consolidar e estruturar suas atividades e continuam atuando no início da cadeia de beneficiamento dos materiais recicláveis. 
A dispersão da cadeia de trabalhadores que atuam no mercado informal de reciclagem provoca uma certa dificuldade em associar diretamente o trabalho dos catadores à demanda por materiais recicláveis realizada pelas grandes indústrias. Entretanto, apesar da fragilidade deste vínculo, a indústria recicladora é um forte determinante sobre o trabalho executado pelos catadores (LEGASPE, 1996).

Frente à conscientização da questão ambiental pela sociedade, a indústria aumenta a utilização de recicláveis que são reinseridos na produçăo. Devido à falta de um gerenciamento adequado, que responsabilize as atividades de produçăo e consumo geradoras de resíduos sólidos urbanos, é o trabalho depreciado realizado pelos catadores que garante os altos índices de reciclagem, observados no país.

"Em nossa sociedade, um dos principais objetivos sociais é a busca por um padrăo de vida mais alto" (GALBRAITH, 1987).

A busca pela maximização do bem-estar gera uma crescente inovaçăo dos produtos, estratégia utilizada pela indústria na competição de mercado.

A inovaçăo constante de produtos reduz a vida útil, aumentando a obsolescência, especialmente nos produtos micro-eletrônicos e de embalagens, o que aumenta a velocidade e a quantidade no descarte de produtos inutilizados.

"No ato do consumo já existe o descarte de embalagens que só servem para maquiar, são produtos que deveriam ser assim descritos: compre e jogue fora, pois ninguém guarda as caixas de papel de embrulho dos seus produtos por longo tempo" (LEGASPE, 1996).

Assim, o discurso centrado na reciclagem desvirtua o enfoque dado por algumas correntes ambientalistas de redução do desperdício antes do seu reaproveitamento. $O$ conceito dos $3 \mathrm{Rs}$, que envolve primeiro a redução nos resíduos gerados, depois a reutilização e após estas etapas, a reciclagem, é esquecido ou deixado num segundo plano. 
Isto ocorre devido à valorização econômica da reciclagem. No mercado de reciclagem, o preço do material reflete apenas o valor privado do reaproveitamento. $O$ que determina o nivel de reciclagem no processo produtivo é a relação entre o custo de utilizar a matéria-prima virgem e a matéria reaproveitada. Quanto maior for o custo de se extrair matériaprima virgem maior será o incentivo à reciclagem de materiais. É isto que justifica os altos índices de reciclagem para o alumínio, por exemplo (SÉROA da MOTTA e SAYAGO, 1998).

Neste cenário, o mercado de reciclagem em expansão, atrai o investimento de setores com maiores disponibilidades de capital para estes espaços na economia, até então ocupados pelo trabalho desvalorizado dos catadores.

Os pequenos negócios informais de reciclagem encontram-se subordinados ao movimento realizado pelas grandes empresas organizadas, numa posição extremamente vulnerável (SOUZA, 1981).

Entretanto, a reciclagem mais do que uma atividade privada de reaproveitamento de materiais é uma das etapas para um gerenciamento adequado dos resíduos.

A mudança no padrăo de consumo e o crescente aumento na produção de descartáveis, aumenta a geração de resíduos que provocam a extraçăo e degradação dos recursos naturais. No entanto, estes custos sociais provocados ao meio ambiente não são incorporados nas decisões privadas de investimento e de consumo.

Pode-se dizer que o principal papel do Estado deve ser a intermediação entre os interesses particulares e os interesses coletivos, neste caso, a preservação do meio ambiente, através da redução na geração de resíduos e a utilização de formas mais adequadas de tratamento e de destinação final.

A falta de uma legislaçăo ambiental, ou de sua efetiva aplicação, que regulamente a responsabilidade na geraçăo dos resíduos sólidos urbanos perpetua esta estrutura produtiva poluente. 
Assim, a degradaçăo ambiental provocada pela geração de resíduos exige a ação governamental para a prestaçăo de serviços de limpeza urbana, entre eles: a coleta, a administraçăo e manutenção de aterros sanitários, o desenvolvimento de formas alternativas de tratamento e disposição final dos resíduos gerados, os programas de coleta seletiva e a varrição de vias e logradouros públicos.

No caso da coleta dos resíduos recicláveis, os custos são arcados ou pelo Estado, que toma para si a responsabilidade no tratamento, ou pelo trabalho desvalorizado dos catadores, quando eles realizam a coleta.

Entretanto, políticas ambientais que incluam os custos sociais da degradaçăo ambiental podem induzir o comportamento dos indivíduos e, com isso, provocar uma reduçăo de resíduos na fonte geradora (CHERMONT e SERÓA da MOTTA, 1996).

Entre estas políticas pode-se citar a adoção de uma taxa de limpeza urbana. Ao ser tributado um valor de acordo com a quantidade de resíduos gerados, esta política pode provocar uma redução na fonte geradora, além de promover a arrecadação de recursos para o Estado. Estes recursos poderiam ser utilizados para o estímulo e 0 incentivo à reciclagem, incluidas as atividades realizadas pelos catadores.

Para abordar os diversos aspectos que envolvem o trabalho dos catadores, no primeiro capítulo é feita a discussăo e a definição das atividades informais, suas características e suas necessidades. $\dot{E}$ definido o espaço de atuação reservado aos pequenos produtores, que prestam serviços ao mesmo tempo em que concorrem com a organização de grandes empresas capitalizadas. É discutida também a alternativa proposta pelo sistema cooperativista, de apropriação coletiva do capital, assim como a dificuldade em estruturar estas iniciativas populares de economia solidária, inseridas num ambiente em que são dominantes as regras estabelecidas pelo mercado.

A utilização da reciclagem pelas grandes empresas, no reaproveitamento dos materiais descartados pós-consumo, é o tema desenvolvido no segundo capítulo. É feita a descrição da estrutura do 
mercado informal da reciclagem. Além disso, é feita também a descrição da indústria nacional do alumínio e do papel e as estratégias utilizadas por estas indústrias para tomar mais eficiente a coleta dos materiais recicláveis, que serão reutilizados na produçăo.

No terceiro capitulo são discutidas a questão ambiental dos resíduos sólidos urbanos $e$ as formas de tratamento sugeridas pelas correntes neoclássica e institucionalista da teoria econômica ambiental. Discute-se o papel das instituições govemamentais no controle e na regulação dos serviços de limpeza urbana e na garantia da manutenção sustentável de um ambiente saudável. Nesta discussão desenvolve-se amplo debate sobre o provimento de recursos do orçamento público para a manutenção dos serviços de limpeza urbana e para o incentivo às atividades de reciclagem, desenvolvidas também pelas cooperativas de catadores.

Como complementação, foi realizado um estudo de caso em três cooperativas da Região Metropolitana de São Paulo, descrito no quarto capítulo. Este estudo teve o objetivo de identificar a estrutura destas cooperativas e suas relaçōes com as prefeituras municipais, com o mercado de reciclagem e com a sociedade civil.

Esta pesquisa toma como corte de análise as cooperativas de catadores que estão inseridas nos programas municipais de coleta seletiva de lixo, realizados por algumas prefeituras.

A definição da situação destas cooperativas permite diagnosticar as principais causas favoráveis, e necessárias, para consolidar as atividades realizadas por estes catadores.

A busca por uma inserção mais consolidada no mercado de reciclagem e de relações entre estas cooperativas e o poder público, que não se restrinjam apenas ao caráter assistencialista, é essencial para garantir a permanência e 0 desenvolvimento do trabalho dos catadores, através da economia solidária.

É relevante para a promoção da saúde pública, a possibilidade de criar alternativas de geração de trabalho e renda para este segmento 
marginalizado da população. Além de promover a valorização no trabalho destas pessoas, estas iniciativas incentivam 0 desenvolvimento sustentável, numa relação melhor do homem com o meio em que vive. 
incubação para se tornar uma cooperativa, os catadores do Projeto Vira Lata ainda não estão formalizados como uma cooperativa.

Entretanto, o apoio dado pela diretoria é bastante dinâmico e têm sido fundamental para consolidar o trabalho dos catadores envolvidos no Projeto, pelo sistema cooperativista.

Graças a este apoio, as atividades de educação ambiental são realizadas até hoje, nas residências, comércios e condomínios e também por palestras em escolas da região.

Além disso, durante um período de dois anos, foi editado o Boletim Vira Lata, com a divulgação da contabilidade do Projeto Vira Lata para todos os seus colaboradores. Este Boletim incluía, ainda, textos sobre diversos assuntos, como meio ambiente, reciclagem, cooperativismo, e mercado de trabalho. Com a extinção do Boletim, a prestação de contas para a sociedade continua a ser feita através da internet, via e-mail.

A contabilidade dos dados é feita pelos próprios catadores, entretanto devido à falta de computador e à falta de acesso à internet, a divulgação destes dados é feita pelo presidente da diretoria, que conta também com a ajuda de outros voluntários.

Devido a este processo de transparência nas informações e à abordagem direta com a sociedade civil o Projeto Vira Lata conquistou, cada vez mais, o apoio de toda a comunidade local.

Atualmente, a atividade de coleta não é mais realizada por carrinhos. Agora, a coleta é feita no sistema porta a porta por 2 caminhões e 1 veículo Topic, nos bairros do Butantã, Jaguaré, Raposo Tavares, Rio Pequeno e Vila Sônia.

O Projeto Vira Lata conta com o apoio, através da doação de materiais, de condomínios residenciais e algumas empresas localizadas nas proximidades da Rodovia Raposo Tavares, como supermercados e shopping centers, além das doações feitas pela Editora Globo e pela Associação Comercial de São Paulo. Também são realizadas parcerias com 15 escolas públicas, onde se desenvolve a conscientização a respeito da questão do lixo e da reciclagem. 


\section{Metodologia}

\subsection{Referencial Teórico}

Para a discussão do trabalho informal dos catadores, as suas características, o espaço que ocupam no mercado e as possibilidades pela organização do trabalho em cooperativas, o referencial bibliográfico baseou-se, principalmente, nos seguintes autores: Pamplona, Cacciamali, Pochmann, Singer e Boaventura de Souza Santos.

Para a análise da reciclagem nas indústrias de alumínio e de papel a pesquisa utilizou estudos sobre a competitividade da indústria brasileira, realizados por uma equipe de pesquisadores do Instituto de Economia da Unicamp, além de relatórios produzidos pelo BNDES e pela Associação Brasileira de Aluminio - ABAL.

Para a discussão sobre o papel do Estado na incorporação dos custos sociais, nas atividades de produção e de consumo que geram resíduos sólidos urbanos, e do incentivo às atividades realizadas pelos catadores e recicladores, foram consultados os autores: Amazonas, Tayra, Sêroa da Motta, Chermont, Romeiro e Salles Filho, além de dados do IBGE, pela Pesquisa Nacional de Saneamento Básico -2000 , e da análise dos Anteprojetos de Políticas Nacional e Estadual de Resíduos Sólidos.

Foram utilizadas bases bibliográficas das bibliotecas da Faculdade de Saúde Pública, Faculdade de Filosofia, Letras e Ciências Humanas, Faculdade de Economia e Administração e Faculdade de Direito da Universidade de São Paulo, da Pontifícia Universidade Católica de São Paulo e do Compromisso Empresarial para a Reciclagem - CEMPRE.

\subsection{Pesquisa de Campo}

Foi realizado um estudo descritivo qualitativo, com coleta de dados primários através de um estudo de caso em três cooperativas de catadores de materiais recicláveis situadas na Região Metropolitana de São Paulo. 


\subsection{Seleção da amostra}

As três cooperativas foram selecionadas, em primeiro lugar, pela disponibilidade de registro dos dados contábeis sobre a comercialização dos materiais coletados e, em segundo lugar, pelos diferentes motivos que geraram as iniciativas para a formação de cada cooperativa.

Além disso, foram selecionadas cooperativas situadas em cidades diferentes, o que permitiu analisar as especificidades existentes em cada programa municipal para a inclusão dos catadores na coleta seletiva.

As cooperativas selecionadas foram: A Cooperyara, no município de Barueri, a Associação Raio de Luz, em São Bernardo do Campo, e o Projeto Vira Lata, em São Paulo.

A Associação Raio de Luz e a Cooperyara foram organizadas por iniciativa das respectivas prefeituras municipais, para a valorização do trabalho dos antigos catadores dos lixões. Apesar desta semelhança, existem algumas diferenças na execução destes programas, em andamamento. Em Barueri a coleta é feita pelo sistema porta a porta e a Cooperyara é a única cooperativa do município. Já em São Bernardo do Campo a coleta é realizada por meio de Pontos de Entrega Voluntária PEV's e são duas cooperativas incluidas no programa da prefeitura.

Já o Projeto Vira Lata foi fundado graças a iniciativa da Associação de Moradores do Bairro Jardim Boa Vista. A partir de outubro de 2003, o Projeto Vira Lata começou a participar do programa municipal de coleta seletiva da prefeitura de São Paulo, mas é uma participação complementar e os catadores mantêm autonomia em relação à prefeitura, realizando com recursos próprios a coleta dos materiais recicláveis. Além disso, está em fase de implantação um projeto financiado pela Petrobrás, para a construção de uma usina para a fabricação de telhas ecológicas. 


\subsection{Coleta De Dados}

A coleta de dados primários referentes à comercialização dos materiais e às despesas foi realizada nas próprias cooperativas, as quais contavam com o registro destes dados.

Foi elaborado um questionário semi-estruturado para entrevistas com os presidentes, vice-presidentes e secretários financeiros em cada cooperativa selecionada.

As informações a respeito do contrato realizado com a prefeitura foram obtidas através das entrevistas realizadas com os funcionários e gestores municipais dos programas analisados.

\subsection{Pesquisa por entrevistas}

Foram realizadas entrevistas a técnicos da Secretaria Municipal do Meio Ambiente de São Bernardo do Campo, e da Secretaria Municipal de Recursos Naturais e Meio Ambiente do município de Barueri, para analisar a inclusão das cooperativas de catadores nos programas municipais de coleta seletiva. No caso do Projeto Vira Lata, como a iniciativa surgiu da Associação de Moradores do Bairro Jardim Boa Vista, foram realizadas entrevistas com integrantes desta associação.

\subsection{Análise dos Dados}

Foram elaborados três indicadores referentes aos dados quantitativos sobre a comercialização de materiais recicláveis e sobre as despesas e as receitas, em cada cooperativa analisada:

- INDICADOR 1 - Quantidade de material comercializada por catador: permitiu identificar possíveis diferenças na inclusão destas cooperativas nos programas municipais de coleta seletiva de lixo.

- INDICADOR 2 - Percentual de despesas sobre receitas: para avaliar a relevância do apoio nos custos arcados pelas cooperativas

- INDICADOR 3 - Composicão do material coletado: para identificar possíveis diferenças nos materiais comercializados que poderiam provocar diferenças nas receitas obtidas, entre as cooperativas. 


\section{REVISÃo BIBLIOGRÁFICA}

\subsection{O trabalho autônomo dos Catadores de materiais RECICLÁveis No SETOR INFORMaL da RECICLAGEM}

\subsubsection{Setor Informal: Mudanças Histórico-Conceituais}

Geralmente, a principal justificativa utilizada para explicar o crescimento do setor informal é os altos niveis de desemprego. Assim, as atividades informais são definidas como aquelas realizadas por trabalhadores pobres que visam gerar renda e garantir a própria subsistência.

Entretanto, esta associação do aumento do setor informal com o desemprego, apesar de não estar errada, pode ser aprofundada. Através de uma revisão nas mudanças histórico-conceituais na definição sobre o setor informal, pode-se identificar as reais causas que levam os trabalhadores para a informalidade.

Segundo Cacciamali (1991), pode-se dividir a definição sobre o setor informal em duas fases distintas: a primeira fase elaborada no início dos anos 70 , e a segunda fase desenvolvida em meados da década de 80.

O marco inicial foi dado pela Organização Internacional do Trabalho (OIT), que, em 1972, realizou o primeiro estudo sobre o setor informal. Através de relatórios sobre o mercado de trabalho nos países de Gana e Quênia, foi constatado que ao invés do desemprego, o principal problema social destes países era o grande número de atividades informais (JAKOBSEN, 2000).

Como desenvolvimento deste primeiro estudo, realizado pela OIT, o setor informal passou a ser definido como o espaço ocupado na economia pelo excedente de mão de obra não incorporado pelo desenvolvimento econômico.

Estas pessoas, quando não encontravam espaço para atuação no setor formal da economia, ou seja, quando não encontravam emprego, 
passavam a desenvolver atividades que não eram regulamentadas, protegidas ou reconhecidas pelas instituiçōes públicas.

O enfoque utilizado nesta primeira fase para definir a informalidade foi a questão da ilegalidade. Desta forma, o setor informal era tratado como as atividades de trabalho que não cumprem todas as regras institucionais, sejam estas fiscais, trabalhistas, sanitárias, ou de qualquer outro tipo, mas que seu produto é lícito, ao contrário, por exemplo, do tráfico de drogas (ROMEIRO, 2001; KON, 2001).

Cabe ressaltar que, segundo esta definiçăo, o que determina a ilegalidade nas atividades informais é a inviabilidade, ou seja, uma real dificuldade de cumprir todas as normas vigentes, já que o excedente gerado não seria suficiente para isto (PAMPLONA, 2001b).

Assim, o setor informal era definido em contraposição ao setor formal da economia. Era analisado como um setor homogêneo de atividades realizadas por trabalhadores pobres e desempregados. Desta forma, a ocupação do trabalho na economia era dividida, de maneira simplista, em apenas dois setores, formal-informal. Além disso, a origem da informalidade estaria vinculada ao atraso econômico dos países e sua solução seria o crescimento econômico (CACCIAMALI, 1991).

Nesta primeira fase, o setor informal foi definido como um problema conjuntural da economia, um fenômeno típico dos países em desenvolvimento, conseqüência do atraso no desenvolvimento do capitalismo.

Na verdade, o que permitiu a consolidação desta definição sobre o setor informal foi a formação de um amplo arcabouço institucional criado para regulamentar a contratação da mão de obra, durante a fase dourada do capitalismo, que durou do pós-guerra até meados da década de 70 (POSTER e CASTELLS, 1989 citado por PAMPLONA, 2001a).

Foram condiçőes especificas no desenvolvimento econômico, que permitiram a conquista de direitos pela classe operária, através do emprego assalariado regulamentado, que é um contrato permanente de trabalho, regido por lei, determinando as condiçōes mínimas para o 
exercício do trabalho e o acesso aos serviços da seguridade social (CACCIAMALI, 2001; PAMPLONA, 2001b).

Esta institucionalização da garantia ao direito do trabalho resultou numa homogeneização dos contratos trabalhistas, especialmente nos países do centro capitalista europeu.

As novas tecnologias da $2^{a}$. Revolução Industrial e a produção em série e em grande escala, introduzidas pelo modelo de organização industrial taylorysta-fordista, permitiram a incorporação em massa de mão de obra não qualificada, na produção de novos produtos.

Foi criado um ciclo no desenvolvimento econômico e industrial, que estava baseado num tripé de sustentação ou num círculo virtuoso entre aumento da capacidade produtiva, aumento do consumo e aumento do emprego.

Nesta fase, foi formado um ambiente mais favorável à classe trabalhadora, pois ocorreu grande transferência de renda aos salários, feita em parte pelos lucros e em parte pela forte presença do Estado na economia, através das políticas keynesianas, que permitiu aos trabalhadores tornarem-se também consumidores e terem amplo acesso aos serviços públicos de seguridade social.

"Nos paises avançados, em cada 10 trabalhadores, de 8 a 9 eram assalariados. Estes índices de pleno emprego atingidos foram objetos de construção social, arranjos políticos e institucionais, em que a geração de emprego público foi fundamental para garantir a quase plena ocupação da força de trabalho" (POCHMANN, 2000, p.19).

Ocorreu o que Castel (1998) denominou de sociedades salariais, com a homogeneização das relaçōes trabalhistas, através do emprego assalariado regulamentado.

Cabe ressaltar que, nos paises periféricos estas mesmas condições de homogeneização do trabalho, pelo emprego assalariado regulamentado, também ocorreram, mas em menor escala e englobaram uma parcela relativamente menor da população. 
Isto ocorre porque o que determina a regulamentação nos contratos trabalhistas são características especificas no desenvolvimento histórico, nos marcos institucionais e nas conquistas sociais ocorridas em cada país (CACCIAMALI, 1989).

No caso do Brasil, o desenvolvimento econômico foi realizado, em grande parte, pela substituição de importações, um modelo importador de tecnologias, que manteve a concentração de renda do periodo agrícolaexportador e não permitiu o pleno desenvolvimento do mercado intemo, restringindo a produção e o consumo a uma pequena parcela da população (FURTADO, 1964; TAVARES, 1973).

A impossibilidade do mercado interno em absorver a grande oferta de trabalhadores que migravam para as grandes cidades em busca de emprego revelaram que, mais do que um problema conjuntural, o setor informal era um problema intrínseco à estrutura de desenvolvimento realizado nos países periféricos.

Assim, visando aperfeiçoar a definição sobre o setor informal, dada inicialmente, o Programa Regional do Emprego para a América Latina e o Caribe (PREALC), um programa já extinto da OIT, passou a definir o setor informal como um problema estrutural enfrentado pelos trabalhadores, nas cidades latino-americanas (PAMPLONA, 2001a).

Colabora para esta revisão no conceito do setor informal uma nova onda de inovação tecnológica que provocou mudanças na incorporação do trabalho pelo processo produtivo.

A $3^{a}$. Revolução Industrial, com 0 desenvolvimento da microeletrônica, permitiu a descentralizaçăo do capital, dando maior mobilidade à contratação do trabalho.

Associado a este processo, a abertura comercial e a liberalização financeira tornaram o cenário mais competitivo e as grandes empresas, na busca pela redução nos custos, passaram a flexibilizar os contratos trabalhistas, com a terceirização e a subcontratação da mão de obra.

A crise do modelo taylorista-fordista de organização da produção implicou na rarefação dos contratos permanentes de trabalho, pelo 
emprego assalariado regulamentado. Os trabalhadores, que estavam inseridos de maneira formal, passaram a sentir os efeitos da flexibilização nos contratos.

É o Processo de Informalidade, definido por Cacciamali (2001, p. 117) como "um processo de destruição, adaptação e redefiniçāo das relações de produção, processos de trabalho, formas de inserção do trabalho, contratos de trabalho e conteúdo das ocupações. (...) Neste processo as relações de trabalho são substituidas por relaçōes comerciais".

Assim, o setor informal, que na primeira fase foi definido como um setor homogêneo e um problema conjuntural da economia, na segunda fase da definição passa a tratado como um problema estrutural do desenvolvimento econômico, observado também nas economias avançadas (DEDECCA, 1996).

Desta forma, o crescimento econômico, antes considerado como a soluçăo para a informalidade, passa a ser visto como o que determina a formação e o aumento do setor informal.

A informalidade não é conseqüência da ausência do desenvolvimento capitalista, mas sim da presença e do domínio desta forma de organizar a produção (PAMPLONA, 2001a).

O emprego assalariado regulamentado é uma das formas de incorporar a mão de obra no processo produtivo. Neste contrato, o empregador, que é proprietário do capital, compra a capacidade de trabalho do empregado (SINGER, 1996).

Como vimos, a hegemonia desta forma de contratar o trabalho dependeu da forma de organizar a produção em um determinado contexto histórico no desenvolvimento do capitalismo.

O que determina a participação dos trabalhadores na produção é a forma de organização social da produçăo de riquezas, ou seja, a participação dos trabalhadores não é autônoma, mas depende do modelo e da intensidade do desenvolvimento económico (POCHMANN, 2000). 
Com o desenvolvimento tecnológico, ao mesmo tempo em que se aumenta a capacidade produtiva, é diminuida a absorção de trabalho, alterando a inserção dos trabalhadores, assim como seu vínculo empregatício.

"A economia informal não é sinônimo de pobreza, mas uma forma especifica de relação de produção. (...) É um processo que atravessa a estrutura social inteira. (...) A maioria das atividades no setor informal derivam da necessidade desesperada de trabalhadores em garantir sua sobrevivência e de sua familia. Mas, uma motivação similar pode levar o trabalhador a aceitar baixos salários no setor formal. (...) Além disso, algumas experiências informais permitem obter niveis de renda relativamente altos se comparados aos que estes trabalhadores obteriam através de um emprego no setor formal da economia (POSTER e CASTELLS, 1989 citado por PAMPLONA, 2001a, p. 30)".

Neste contexto, apesar de todo 0 aparato institucional criado para regulamentar os contratos de trabalho, o que se observa na prática é a consolidação das formas de flexibilização trabalhistas, pelo processo de informalidade (CACCIAMALI, 2001).

"O capitalismo está conseguindo criar o trabalho puro, isto é, o trabalho que não envolve nenhuma responsabilidade social e moral do empregador (...) é a terceirização do trabalho, ou seja, o trabalhador é empregado dele mesmo. $O$ trabalho não envolve nenhum encargo social, nenhuma responsabilidade a ninguém" (MARTINS, 2002 citado por SABBAG, 2003, p. 80).

Segundo Kon (2001), a definição sobre o setor informal acompanha as mudanças na organização da produção. Se antes, era possivel tratar a economia informal como sinônimo de pobreza, atualmente, com a flexibilização nos vínculos empregatícios, esta definiçăo é alterada, de acordo com as transformaçōes ocorridas no desenvolvimento econômico mundial.

Cabe ressaltar que, estas mudanças na definição do setor informal colaboraram para aumentar a controvérsia existente entre as diferentes 
correntes que discutem o setor informal. Ainda hoje, diversos autores possuem posturas diferentes quanto à origem da informalidade, quanto à sua definição ou quanto às soluções recomendadas para estruturar estas atividades de trabalho'.

Para analisar a situação do trabalho dos catadores de materiais recicláveis no setor informal da reciclagem, o corte de análise adotado nesta pesquisa será focalizado na composição do setor informal e no espaço ocupado por estes trabalhadores na economia.

\subsubsection{Composição do Setor Informal e Características das Atividades Realizadas pelos Catadores}

Atualmente, trabalhadores em diferentes condições atuam no setor informal. Antes tratado como um setor homogêneo de atividades de baixa produtividade, após a flexibilizaçăo trabalhista e a terceirização da produção, o setor informal engloba, também, atividades extremamente especializadas, incluindo uma gama diversa de situações de trabalho.

Atuam na informalidade, tanto trabalhadores com qualificação especialmente alta, os quais prestam serviços como educação, medicina, ciência e cultura, quanto trabalhadores não-qualificados, como os domésticos e assistentes baratos de empresas de serviços.

Pode-se dividir estes trabalhadores em três grupos: aqueles permanentemente pobres, com capital técnico e humano inexistente, que usam o informal como meio de subsistência; aqueles desempregados conjunturais que atuam esporadicamente na informalidade, ou por um tempo reduzido; e um grupo menor de empreendedores, donos de micro e pequenas empresas, que possuem algum potencial para prosperar como auto-empregado (RAKOWISKI, 1996 citado por PAMPLONA, 2001a).

\footnotetext{
${ }^{1}$ Para um resumo sobre as diferentes correntes que discutem o setor informal consultar PAMPLONA, 2001a.
} 
Assim, diferentemente do critério da ilegalidade, adotado na primeira definição sobre o setor informal, a partir de meados dos anos 80 , a segunda definição sobre o setor informal, para atender às diversas situações de trabalho informal, passa a adotar como foco de análise a forma de organizar o trabalho. Esta forma ocorre tipicamente pelo autoemprego (ROMEIRO, 2001; CACCIAMALI, 1989).

O auto-emprego define as pessoas que atuam independentemente e controlam seu próprio trabalho; fornecem a si próprio o equipamento utilizado e a renda obtida não é previamente definida. O principal objetivo dos auto-empregados é prover e manter seu próprio emprego, e não valorizar o capital, que passa a ser um objetivo secundário (PAMPLONA, 2001b).

Frente ao crescimento do auto-emprego, grande ênfase é dada ao empreendedorismo, entretanto, é preciso diferenciar as características destes auto-empregados que determinam as condições para obter êxito nestes empreendimentos.

Pamplona (2002) analisa as diferentes causas que colaboram para o crescimento do auto-emprego e as divide em dois grupos: as causas que obrigam $\mathrm{e}$ as causas que atraem as pessoas para o auto-emprego. $\mathrm{A}$ queda da qualidade do emprego assalariado, o aumento do desemprego e a flexibilização nos contratos trabalhistas obrigam a ida para o autoemprego. Já, a possibilidade de se especializar em novas áreas, pelas novas tecnologias de informática ou a possibilidade de atender a expansão da demanda por produtos diferenciados são causas que atraem as pessoas para o auto-emprego.

Além das causas que levam as pessoas para o auto-emprego, existem condições na organização e no tipo de trabalho a ser oferecido que facilitam a consolidação destas atividades.

Geralmente, as atividades mais promissoras possuem uma quantidade relativa de capital inicial; podem desviar menos excedente gerado pelo negócio para o consumo familiar, o que permite maior capacidade de investir; possuem mais qualificações técnicas e 
profissionais; dispõem de um "nicho de mercado" e seus relacionamentos sociais estão inseridos em setores de renda mais alta ${ }^{2}$.

A grande maioria dos auto-empregados, principalmente nos países em desenvolvimento, não possui estas características impossibilitando a obtenção de sucesso e lucros em suas atividades, sendo apenas uma forma de obter renda para a sobrevivência e a manutenção da autoestima.

Neste caso encontram-se os catadores que são auto-empregados ou trabalhadores por conta-própria "empurrados" para a informalidade.

O trabalho dos catadores está inserido no setor informal da reciclagem, pela comercialização de materiais recicláveis aos intermediários ou à indústria recicladora.

A descrição da própria situação de trabalho feita por uma catadora, Carolina Maria de Jesus, revelam a vulnerabilidade de seu trabalho (JESUS, 2001).

"Fiz café da manhã e mandei os filhos lavar-se para ir na escola. Depois saí e fui catar papel. Passei no Frigorífico e a Vera foi pedir salsicha. Ganhei só 55 cruzeiros. (...) Passei numa casa da Avenida Tiradentes e levei 50 quilos de papel que uma senhora deu-me para vender para ela. Levei na cabeça e vendi. Deu 100 cruzeiros. Ela ficou alegre" (JESUS, 2001, p. 102.)

"Parei na linha do trem para pegar umas latas porque eu havia deixado perto da gurita e pedi ao guarda para guardar. $\mathrm{O}$ guarda perguntou quanto eu ia receber das latas. Respondi que era 300,00. Que já estou farta de biscates. Ele disse antes isso do que nada. Eu disse-lhe que as latas de óleo eram 70,00 e agora está a 60,00" (JESUS, 2001, p. 116.).

\footnotetext{
${ }^{2}$ Por exemplo, o cabeleireiro que atende clientela de alta renda, atuando num mercado diferenciado, com possibilidade de obter lucros maiores, visto que não precisa competir com muitos concorrentes. (PAMPLONA, 2001a).
} 
Este trabalho realizado em condiçōes precárias pode ser responsabilizado, em grande parte, pelos altos índices de reciclagem atingidos pelo Brasil, o mais alto, no caso de alguns materiais, entre os países que não possuem regulamentação para estas atividades.

Entretanto, apesar dos altos niveis já atingidos e do crescimento nas atividades de reciclagem, o trabalho dos catadores não possui as caracteristicas necessárias para $\circ$ crescimento e a consolidação de suas atividades.

Os catadores são auto-empregados com baixa qualificação e por isso são obrigados a realizar ocupaçōes que exigem pouco capital e pequena escala de produção, com quase nenhum capital técnico ou humano, com processos tecnológicos simples, nos quais, normalmente, a tecnologia é adaptada. Além disso, estas atividades possuem utilização intensiva de trabalho, são realizadas em setores da produção onde ocorre facilidade de entrada por outros concorrentes, ou seja, num mercado competitivo e não regulado (CACCIAMALI, 1991; KON, 2001; PAMPLONA, 2001a).

Devido a estas caracteristicas é fundamental a existência de mecanismos de apoio, seja da sociedade civil, seja do poder público, seja entre os próprios catadores, para que estas atividades desenvolvam-se como reais potencialidades de garantir trabalho e renda, para este segmento marginalizado da população.

\subsubsection{Espaço de atuação das atividades informais}

Durante a década de 70, o setor informal era tratado como um setor separado da economia formal, já que na sua composição eram incluidas apenas as atividades realizadas pelo excedente de mão de obra não incorporado no processo produtivo.

Entretanto, a partir dos anos 80 , com a nova organização da produção proporcionada pela $3^{\mathbf{a}}$. Revolução Industrial, as grandes 
empresas passaram a flexibilizar os contratos trabalhistas, pelo processo de informalidade. (CACCIAMALI, 2001).

Estas alteraçōes na organização produtiva permitiram que o setor informal deixasse de ser tratado como um setor à parte da economia formal para ser analisado como um setor que depende, que é criado e que está ligado ao processo de acumulação de capital.

Na verdade, é a concentração de capital que garante a expansão tecnológica e permite a formação de novas relaçōes entre o capital e o trabalho.

Assim, no mercado, a produção é realizada por diferentes unidades produtivas, que englobam tanto os auto-empregados informais, quanto pequenos negócios, ou as grandes empresas organizadas.

Segundo Souza (1981), o que viabiliza a acumulação de capital, entre outras coisas, é a existência de uma concentração de mercado suficiente para permitir a acumulação de lucros e a expansão da capacidade produtiva. Só que neste cenário é a grande empresa que tem maior poder para conduzir e, até mesmo retroalimentar, a própria acumulação de capital.

"Por exemplo, em algumas atividades, a pequena produção é destruida pela penetração das empresas capitalistas: os pequenos armazéns e o pequeno comércio têm o seu "espaço econômico" ocupado pela instalação dos supermercados, entretanto, estas pequenas produçōes têm a possibilidade de reproduzir-se nos bairros novos, onde o mercado ainda não é concentrado para permitir a instalação de empresas capitalistas" (SOUZA, 1981, p. 59).

Assim, o espaço para o desenvolvimento das atividades informais é definido e regulado pelo núcleo organizado das grandes empresas organizadas de maneira tipicamente capitalista. $O$ setor informal desenvolve-se nos espaços intersticiais da economia, nos espaços não ocupados pelo grande capital (CACCIAMALI, 1989).

Devido à existência de espaços no mercado que não permitem a acumulação de capital necessária para a instalação de grandes firmas 
organizadas são formados pequenos espaços econômicos onde diversos trabalhadores informais realizam suas atividades.

No caso dos catadores de materiais recicláveis, o espaço econômico utilizado tem origem na falta de regulamentação para o setor da reciclagem, especialmente no caso dos resíduos sólidos urbanos.

A crescente geração de resíduos, provocada pela mudança no comportamento da população que consome, cada vez mais, produtos industrializados, gera uma abundante oferta de materiais recicláveis, que estão dispersos pela cidade, ou descartados de maneira inadequada nas ruas e nos lixões.

"A cidade se assemelha a uma "floresta urbana" cheia de recursos que podem ser reinseridos no processo de produção. É como se ela fosse capaz de prover recursos que ela mesma consome. Mesmo não possuindo petróleo, produz plástico, (...) ou ainda, fornece à indústria de metais, ferro, aço, alumínio, mais do que muitas fontes de matérias primas naturais. A cidade assim se transforma em produtora de materiais que ela mesma consome e (re)produz em forma de lixo, que será insumo quando as mãos dos catadores os coletarem" (LEGASPE, 1996, p. 12).

Nestes pequenos espaços econômicos do setor informal da reciclagem diversos trabalhadores atuam na recuperação e no beneficiamento dos materiais inutilizados. Estas atividades exigem um grande dispêndio de trabalho, que é segmentado em diferentes funçōes, entre os catadores, intermediários e sucateiros, dispostos numa rede hierárquica que é estabelecida de acordo com a quantidade de maquinário utilizada.

Devido a este caráter disperso do setor informal da reciclagem existe uma certa dificuldade em associar diretamente 0 trabalho dos catadores à demanda por materiais recicláveis, realizada pelas grandes indústrias, situadas na economia formal (LEGASPE, 1996).

Entretanto, apesar da fragilidade deste vínculo, a indústria recicladora é um forte determinante sobre o trabalho executado pelos catadores e pelo preço pago aos materiais recicláveis. 
Em um cenário de flexibilização e subcontratação de mão de obra, estes auto-empregados que possuem baixa qualificação e reduzida capacidade de investimento encontram-se numa frágil situaçăo, e para diminuir esta vulnerabilidade estes trabalhadores procuram se organizar da melhor maneira possível. Assim, é crescente a organizaçăo de catadores em cooperativas de trabalho, que organizam as suas atividades pelos princípios da economia solidária.

\subsubsection{A Economia Solidária}

A economia solidária é uma proposta alternativa de desenvolvimento que procura inserir nas atividades produtivas, além da motivaçăo econômica, outras variáveis, como a solidariedade, a educaçăo, a cultura e a participaçăo política, numa visão mais holistica para as atividades de produção. (SOUZA e RODRÍGUEZ, 2002).

"É a preocupação de ligar a questão do emprego com a coesão social, de criar vínculos, ao mesmo tempo em que as atividades, entre as pessoas, são respeitadas ao máximo" (CASTEL, 1998, p. 575).

A origem da economia solidária remonta ao século $X I X$, e é tão antiga quanto à origem do capitalismo industrial. Em 1826, na Inglaterra, concomitante à incorporação em massa de camponeses como operários de fábricas, surgiram as primeiras iniciativas de trabalho cooperativo. Este movimento ganhou força, em 1844, quando foi fundada a Cooperativa dos Pioneiros Eqüitativos de Rochdale, uma cooperativa pioneira que deu origem aos principios do cooperativismo. (SINGER, 2002).

Os principios do cooperativismo incluem: a adesão livre e voluntária, ou seja, as cooperativas devem estar sempre abertas a novos membros; a participaçāo democrática nas decisōes, em que todos os membros têm o mesmo direito ao voto; a gestăo democrática dos sócios, ou seja, a autogestăo; a autonomia e a independência tanto em relação ao Estado quanto a outras organizações; o compromisso com a educação dos membros, para que seja garantida uma participação efetiva; e a 
contribuição para o desenvolvimento da comunidade local (SOUZA e RODRIGGUEZ, 2002).

O modelo de "empresa" da economia solidária é a cooperativa, que é uma sociedade de pessoas que se unem, voluntariamente, com seus recursos individuais, para a formaçăo de um capital coletivo. É uma associação autônoma de pessoas que têm o objetivo de garantir suas atividades (BRASIL, 1971).

As cooperativas se desenvolvem e se relacionam com o mercado, mas procuram transformar estas relações de mercado pela solidariedade, através de uma mudança no sistema de propriedade, pela apropriação coletiva do capital pelos trabalhadores, pela autogestão e pela participação democrática nas decisões. (SOUZA e RODRÍGUEZ, 2002).

É na autogestão que reside a principal diferença entre uma cooperativa e uma empresa tipicamente capitalista. A autogestão coletiva resgata a apropriação das decisőes que são tomadas em grupo, incentivando a cooperação e a cidadania. Já, uma empresa capitalista é organizada pela heterogestão, ou seja, numa administração hierárquica do trabalho (SINGER, 2002).

Assim, para garantir a autogestão em uma cooperativa é necessária a composição de uma Assembléia Geral que é o órgão máximo de decisão, onde cada associado tem direito a um voto igualitário. $O$ "quorum" para o funcionamento e deliberaçăo da Assembléia Geral é baseado no número de associados da cooperativa (BRASIL, 1971).

Os objetivos da cooperativa devem estar estabelecidos em estatuto aprovado na Junta Comercial, o que torna a cooperativa uma entidade jurídica. A aplicação dos recursos é decidida pela Assembléia Geral.

Para atingir estes objetivos da autogestão é necessária a participação democrática dos associados através da promoção de atividades de educação, e para isso a cooperativa precisa aplicar recursos em fundos com o objetivo de manter e promover suas atividades. 
De acordo com este princípio, as cooperativas são obrigadas a constituir pelo menos dois tipos de fundos para a aplicação dos recursos: - Fundo de Reserva, destinado a reparar perdas e atender as necessidades para o desenvolvimento das atividades, devendo ser constituído por pelo menos $10 \%$ das sobras líquidas do exercício, e o Fundo de Assistência Técnica, Educacional e Social - FATES, destinado à prestação de assistência aos associados e seus familiares, devendo ser constituído por pelo menos $5 \%$ das sobras líquidas do exercício (BRASIL, 1971).

Assim, pela economia solidária é sugerido um desenvolvimento alternativo, pelos valores de igualdade, solidariedade e cidadania, que visa a inclusão dos setores marginalizados na produção e na participação dos resultados obtidos pelo desenvolvimento (SOUZA e RODRÍGUEZ, 2002).

Entretanto, uma questão central é como garantir a consolidação e o desenvolvimento da prática cooperativa, já que estas iniciativas atuam no mercado e concorrem com as grandes empresas organizadas.

Segundo Singer (2002) o que dificulta o desenvolvimento da economia solidária é que a maior parte de suas unidades atuam isoladamente, com pouco ou nenhum acesso a crédito, a redes de comercialização e à assistência tecnológica. Assim, a luta principal na estruturação deste trabalho, é tirar a economia solidária dos espaços intersticiais da economia, através de uma rede de integração entre as cooperativas existentes nos diferentes ramos de atividade, proporcionando o desenvolvimento de uma dinâmica própria para a economia solidária.

O exemplo do complexo de Mondragón, na Espanha, evidencia empiricamente a necessidade da integração entre as cooperativas para a consolidação da economia solidária.

O complexo de Mondragón obteve êxito pela formação de uma rede de integração entre cooperativas situadas nos diversos setores da economia. Esta rede conta com o apoio e está subordinada a um órgão 
de coordenação central. Este órgão analisa as necessidades de investimento, e promove a realocação de recursos entre os setores mais lucrativos para os setores que passam por dificuldades temporárias. Além disso, existe a possibilidade de redirecionar atividades para os setores em expansão. É um complexo integrado que ainda conta com o apoio do Estado na realização de projetos de pesquisa tecnológica, em programas de estímulo ao emprego e em análises setoriais sobre o mercado. (SOUZA e RODRIGUEZ, 2002).

Cabe ressaltar que a busca de apoio entre as cooperativas e 0 Estado, ou entre estas e outras organizações é extremamente necessária, mas deve ser considerado e analisado o risco de desvirtuar os princípios cooperativistas nestas relações, principalmente 0 da autonomia e independência das cooperativas em relação a estes apoios.

Além da falta de integração entre as cooperativas, um grande empecilho é provocado pela existencia de cooperativas fraudulentas, conhecidas popularmente como "coopergatos". Estas cooperativas denigrem as iniciativas realmente genuínas de constituição do trabalho cooperativo.

"Neste caso, as cooperativas de trabalho se aproximam perigosamente das empreiteiras de mão de obra e das falsas cooperativas, montadas por firmas capitalistas que visam explorar o trabalho dos associados sem lhes pagar as contribuições trabalhistas legais, nem garantir a vigência dos princípios cooperativistas" (SINGER e SOUZA, 2000, p. 22).

Para evitar este risco de aproximação entre as falsas iniciativas cooperativas é fundamental garantir a participação democrática e a autogestão entre os associados.

\subsubsection{As cooperativas de catadores de materiais recicláveis}

As cooperativas de trabalho dos catadores de materiais recicláveis são iniciativas populares de economia solidária, que buscam organizar o 
trabalho precário realizado pelos catadores que atuam individualmente na coleta de materiais recicláveis, nas ruas e nos lixōes.

Estes catadores individuais situam-se na base da cadeia de coleta e beneficiamento dos materiais recicláveis. Possuem apenas a própria força de trabalho, não dispondo nem de espaço nem de maquinário para aperfeiçoar o tratamento dado ao material coletado. Freqüentemente, não são proprietários nem do próprio carrinho utilizado na coleta.

Ao se organizarem em cooperativas, estes catadores, que antes atuavam como concorrentes no mercado, passam a atuar conjuntamente, o que permite agregar valor ao trabalho realizado, pela comercialização conjunta do material coletado.

Algumas destas cooperativas conseguem adquirir maquinários, como os carrinhos ou caminhões utilizados na coleta, e as balanças, prensas ou mesas de triagem, utilizados no beneficiamento dos materiais recicláveis.

Este maquinário, antes inacessivel ao catador individual, permite à cooperativa incluir atividades que antes eram executadas pelos intermediários e sucateiros. Isto significa, que os catadores passam a atuar em segmentos do mercado que possui uma certa barreira de entrada ${ }^{3}$, já que exige uma determinada quantia de capital empregado nas atividades realizadas. A entrada das cooperativas neste segmento cria a possibilidade de venda direta à indústria de reciclagem, aumentado o beneficiamento e o valor de comercializaçăo dos materiais recuperados.

As iniciativas de formação de cooperativas podem ter origem entre os próprios catadores, podem ser estimuladas por organizações da sociedade civil, como associações de moradores de bairros e igrejas e podem ser induzidas pelas prefeituras que procuram incluir os catadores nos sistemas municipais de coleta seletiva de lixo.

\footnotetext{
${ }^{3}$ Com o desenvolvimento das empresas que atuam em um segmento de mercado cresce o tamanho do capital e das tecnologias específicos para a produção, que representam uma barreira à entrada de novos concorrentes neste segmento. Assim, não é um mercado livre para qualquer iniciativa, já que exige o conhecimento e o investimento necessário para a produção.
} 
Neste último caso, a inclusão dos catadores nos sistemas de coleta seletiva de lixo acontece porque, ao utilizarem os resíduos descartados inadequadamente nas ruas e nos lixões, os catadores passam a atuar na área de gerenciamento de resíduos sólidos urbanos ${ }^{4}$, que pela legislação é de responsabilidade das prefeituras municipais.

Segundo o Inventário Estadual de Resíduos Sólidos Domiciliares, produzido pela CETESB, para o ano de 2002, no Estado de São Paulo, existiam 192 municípios que realizavam a disposição de seus resíduos de forma inadequada e era estimado que existiam, aproximadamente, 2.000 catadores nos aterros e lixões (CETESB, 2003).

Frente à valorização da questão ambiental, os programas municipais de limpeza urbana estão sendo progressivamente aperfeiçoados para um gerenciamento adequado dos resíduos sólidos urbanos. Isto inclui o fechamento ou a regularização dos antigos lixões e a execução de programas de coleta seletiva de lixo.

Entretanto, o fechamento dos lixões cria sérios problemas à sobrevivência dos catadores, que antes realizavam suas atividades nestes locais. Para solucionar esta questão, algumas prefeituras passaram a realizar iniciativas de formação de cooperativas entre os catadores.

Estas cooperativas são incluídas nos programas municipais de coleta seletiva de lixo, para realizar a triagem e a comercialização dos materiais recicláveis coletados, que são doados aos seus associados. Além disso, a prefeitura faz a concessão de uso dos equipamentos e máquinas, além do espaço utilizado, pelas cooperativas para a realização de suas atividades.

Algumas destas experiências incluem atividades de capacitação com o objetivo de melhorar e valorizar o trabalho dos catadores. Estas atividades promovem a educação sobre diversos temas como o

\footnotetext{
${ }^{4}$ Os resíduos sólidos urbanos de responsabilidade das prefeituras incluem os residuos domiciliares, os resíduos comerciais de pequenos geradores, num nível estabelecido de acordo com cada legislação municipal, e dos resíduos provenientes da varrição ruas e logradouros públicos.
} 
cooperativismo, o meio ambiente, a reciclagem, além de aulas técnicas sobre a caracterização dos materiais recicláveis.

Já, as cooperativas organizadas por iniciativa própria dos catadores ou pela ajuda de organizações da sociedade civil não contam com o apoio estatal, realizando de maneira autônoma a coleta dos materiais a serem recuperados e comercializados.

Pode-se observar que, seja quando atuam individualmente, seja quando organizados em cooperativas de trabalho, ou mesmo quando incluídos em sistemas municipais de coleta seletiva de lixo, a renda obtida pelos catadores provém da comercializaçāo dos materiais no mercado informal da reciclagem.

Assim, apesar da organização destes trabalhadores, a constituição de uma cooperativa não modifica a condição do trabalho informal e autônomo dos catadores. De acordo com a OIT, os membros de uma cooperativa são classificados como auto-empregados (KON, 2001).

"Os cooperados são trabalhadores autônomos grupalizados, com os quais os compradores não têm um contrato. (...) Isso aumenta sua vulnerabilidade, estando sujeitos a fenômenos de natureza variada econômica, social, tecnológica - que interferem no seu trabalho, principalmente na garantia da continuidade" (OFFE, 1995 citado por SABBAG, 2003).

Desta forma, a união dos catadores em uma sociedade cooperativa não modifica a precariedade do trabalho realizado.

De acordo com a pesquisa de campo realizada por Conceição (2003) mesmo com a organização em cooperativas, $76 \%$ dos cooperados entrevistados não recolhiam INSS e $72 \%$ já tiveram empregos com registro em carteira, sendo que entre estes, em $71 \%$ dos casos, o salário do emprego anterior era maior do que a retirada atual. Além disso, em muitos destes casos, a carga horária do trabalho na cooperativa era maior que a carga do antigo emprego assalariado.

Além disso, cabe ressaltar a necessidade de se garantir a saúde do trabalhador, especialmente nas cooperativas de catadores, já que o 
objeto e 0 ambiente de trabalho apresentam diversas características que implicam em riscos à saúde dos envolvidos.

Esta situação precária no trabalho é comum às iniciativas populares de economia solidária que procuram gerar renda e trabalho a setores marginalizados da população. $E$, além disso, na consolidação de suas atividades estas iniciativas precisam concorrer com as grandes empresas organizadas que atuam no mercado.

As cooperativas de catadores até então estavam inseridas nos espaços intersticiais da economia. Entretanto, em um cenário de valorização econômica da reciclagem esta concorrência é acentuada, pois os espaços antes outorgados pelas grandes empresas organizadas passam a ser considerados nos cálculos económicos, especialmente pela crescente conscientizaçăo ambiental da sociedade.

"As cooperativas de catadores de lixo, possivelmente a médio e a longo prazo, terão baixas possibilidades de sobrevivência, principalmente neste cenário de empresas privadas e, agora, internacionais no ramo de reciclagem (por exemplo: Rodhia, Recipet, etc.)". (CONCEIÇĀO, 2003, pg. 181).

O mercado de reciclagem, em expansão, torna necessária a reavaliação na organização das atividades das cooperativas de catadores.

A autonomia destas iniciativas populares de economia solidária deve ser buscada tanto dentro como fora do Estado. O Estado, muitas vezes atua como um catalizador eficaz e inclusive como o criador de alternativas. $E$, além do Estado, existem possibilidades de interação com outras organizaçōes que são solidárias à causa do trabalho cooperativo. Nenhuma destas possibilidades devem ser descartadas. Este é o desafio central para a economia solidária (SOUZA e RODRÍGUEZ, 2002).

Além disso, cabe ressaltar a necessidade de integração entre as próprias cooperativas de catadores.

"Um dos fatores mais importantes para 0 aparecimento, a sobrevivência e expansão de altemativas para estas cooperativas é a 
existência de um movimento social mais amplo que produza estas alternativas e mantenha a sua integridade" (SOUZA e RODRÍGUEZ, 2002, p. 66).

No Brasil, em 2000, foi criado o Movimento Nacional dos Catadores de Materiais Recicláveis a partir da Campanha "Criança no lixo nunca mais" realizada pelo Fundo das Nações Unidas para as Crianças UNICEF.

Este Movimento tem conseguido desenvolver a dignidade e a autoestima, além de unificar e promover a discussão entre os catadores sobre as principais necessidades para a organizaçăo de suas cooperativas.

Para isto, em 2001, foi realizado $01^{\circ}$ Congresso Latino-Americano de Catadores de Materiais Recicláveis, em Caxias do Sul (RS).

Graças à atuação dos coordenadores do Movimento Nacional dos Catadores, o Ministério do Trabalho e Emprego reconheceu a atividade de cataçăo, que foi incorporada ao Código Brasileiro de Ocupações, pela Portaria 397, de outubro de 2002, sob o número 5192.

Esta classificação da ocupação dos catadores de materiais recicláveis garante a elucidação das especificidades necessárias para o desenvolvimento do trabalho dos catadores.

Apesar deste avanço, os coordenadores do Movimento Nacional dos Catadores reconhecem que este passo não garante a consolidação de suas atividades de trabalho.

Para isso, é fundamental a ampliação e a regularização entre o apoio dado pelo Estado e também a busca de uma maior integração com o setor privado e as organizações do terceiro setor, além da busca pelo papel que pode ser desempenhado por universidades e instituiçōes de pesquisa tecnológica, no aprimoramento do trabalho realizado por estas cooperativas de catadores.

Como o setor informal da reciclagem é subordinado às decisões de investimento das grandes empresas organizadas cabe analisar as estratégias utilizadas pelas grandes empresas para desenvolver e aumentar a reciclagem nas suas atividades produtivas. 


\subsection{A INCORPORAÇÃo dA RECICLAGEM PELAS INDÚSTRIAS}

No Brasil, apesar de não existir uma legislação ambiental, ou a sua efetiva aplicaçăo, para regulamentar a geração de residuos sólidos urbanos e a reciclagem, são altos os niveis no reaproveitamento de materiais pelas indústrias.

Segundo informações do CEMPRE - Compromisso Empresarial para a Reciclagem, para $\circ$ ano de 2002, os indices de reciclagem atingidos no Brasil, apresentados na Tabela 1, foram:

TABELA 1 - Índice de Reciclagem sobre o Total Produzido, em porcentagem, 2002.

\begin{tabular}{|c|c|}
\hline Materiais & $\begin{array}{c}\text { Indices de Reciclagem sobre } \\
\text { o Total Produzido (\%) }\end{array}$ \\
\hline Papel de Escritório & 41,0 \\
\hline Papel Ondulado & 77,3 \\
\hline Plástico Filme & 17,5 \\
\hline Plástico Rígido & 17,5 \\
\hline PET & 35,0 \\
\hline Latas de Alumínio & 87,0 \\
\hline Latas de Aço & 45,0 \\
\hline Vidros & 44,0 \\
\hline Embalagem Cartonada Longa Vida & 15,0 \\
\hline
\end{tabular}

Fonte: CEMPRE, 2003. Elaborado pela autora.

No caso da reciclagem de alumínio, a partir do ano de 2002, o país atingiu a liderança nos niveis de reaproveitamento do metal entre os países em que a reciclagem não está prevista na legislação (ABAL, 2003).

A principal dúvida que surge é como o país, mesmo sem possuir uma legislação especifica para a reciclagem, atinge elevados índices de reciclagem, comparáveis, em relação ao total produzido, a índices atingidos em paises que possuem extensa regulamentação para a 
geração de resíduos sólidos urbanos. Além disso, os programas de coleta seletiva de lixo realizados no país não recolhem uma quantidade suficiente de resíduos sólidos que justifiquem estes índices de reaproveitamento dos materiais pela indústria (LEGASPE, 1996).

São duas as variáveis que explicam estes indices de reciclagem no país e estas variáveis se desenvolveram concomitantemente.

A primeira variável é o trabalho mal-remunerado e precário realizado pelos catadores. A segunda é a crescente valorização da questão ambiental pela sociedade, em geral.

Segundo os relatos de vida da Carolina Maria de Jesus, a atividade de catação urbana já era realizada nas ruas do centro de São Paulo, no ano de 1955 (JESUS, 2001). Isto demonstra que naquela época já existia demanda por parte de alguns setores industriais por materiais recicláveis.

Quanto a segunda variável, a conscientização da questão ambiental, estudos sobre os efeitos danosos da produção no meio ambiente surgiram na mesma época que o capitalismo industrial. Como exemplo, os estudos realizados por Engels (1985) sobre a situação dos operários, na Inglaterra, em 1840, incluem também a discussão sobre os efeitos da produção no ar, na água e no meio ambiente.

A partir de 1968, com o Relatório de Meadows, feito pelo Clube de Roma, que ressaltava sérias restrições ao desenvolvimento econômico e que propunha o crescimento zero frente à urgência da questão ambiental, esta variável finalmente ganhou peso e foi inserida no debate econômico.

$\mathrm{Na}$ verdade, o que explica os altos índices de reciclagem, mesmo sem uma legislação ambiental específica, é a crescente acumulação de capital, que provoca ao mesmo tempo o desemprego e o aumento na obsolescência dos produtos, causando uma maior geração de materiais recicláveis, onde os catadores atuam.

O aumento do desemprego, como visto no primeiro capítulo desta dissertação, provoca o crescimento do setor informal e dos autoempregados na economia. Falta analisar os efeitos da acumulação de capital no aumento da obsolescência dos produtos. 
"Em nossa sociedade um dos principais objetivos sociais é um padrăo de vida mais alto $(. .$.$) isto tem um grande significado para a teoria$ do consumidor (...) ० desejo de adquirir bens superiores adquire vida própria" (GALBRAITH, 1987, p. 172).

A busca pela maximização do bem-estar gera a crescente inovação de produtos, uma das estratégias adotadas pelas indústrias na concorrência de mercado.

Com a acumulação de capital, esta concorrência entre as empresas se faz num mercado oligopolista, ou seja, formado por poucos fornecedores. Num oligopólio a concorrência năo se faz pelo preço, mas pela contínua mudança nos modelos dos produtos, com o objetivo de acelerar as vendas. É a obsolescência planejada promovida pela publicidade, que utiliza o desejo humano por novidades, diversificando os modelos e as marcas do mesmo produto (KAPP, 1966).

As necessidades humanas são divididas em dois grupos: as necessidades absolutas $e$ as necessidades relativas. As necessidades absolutas são facilmente supridas e por elas o problema econômico da humanidade estaria facilmente resolvido. Já, as necessidades relativas são insaciáveis. Deve-se considerar também o componente social do consumo, que têm entre suas utilidades a integraçăo e aceitação numa determinada classe social, valores que são construídos históricos sócioculturalmente (GALBRAITH, 1987).

Segundo a teoria do consumidor, a utilidade marginal é a utilidade para o consumidor em adquirir uma unidade a mais de determinado produto. Um indivíduo que tem já tem uma unidade de um determinado bem, normalmente não vê tanta utilidade em adquirir uma unidade adicional deste mesmo bem.

O que a promoção de vendas faz é contornar o decréscimo da utilidade, através do aumento na diversificaçăo de artigos finos e modelos variados, ou seja, pela criação de novas necessidades ou utilidades (KAPP, 1966). 
Esta estratégia industrial gera uma inovação constante de produtos, o que reduz a vida útil, provocando uma alta obsolescência, especialmente nos produtos micro-eletrônicos e nas embalagens, o que aumenta a velocidade e a quantidade de materiais descartáveis, causando uma crescente geração de resíduos.

"No ato do consumo já existe o descarte de embalagens que só servem pra maquiar, são produtos que deveriam ser assim descritos: compre e jogue fora, pois ninguém guarda as caixas de papel de embrulho dos seus produtos por longo tempo" (LEGASPE, 1996, p. 136).

Esta estrutura de produção e consumo poluentes recebe críticas de diversas correntes do movimento ambientalista, pois implica em danos ao meio ambiente pela extração e degradação dos recursos naturais.

A consolidação e organização do movimento ambientalista funcionou como um catalizador para o aumento da atenção dada à questão ambiental. Esta mudança nos valores sociais quanto à disponibilidade, utilização e preservação dos recursos naturais levou as empresas a incorporarem o desenvolvimento de tecnologias mais limpas e de processos de produção que agridam menos o meio ambiente.

Estas transformaçōes na produção resultam da progressiva mudança na legislação ambiental pela atuação estatal e pela atuação das empresas de certificação ambiental, nos diferentes segmentos do mercado. Este movimento ocorre principalmente nos países desenvolvidos.

Entretanto, a variável ambiental, que inicialmente representa uma restrição para as decisões de investimentos privados, após a sua incorporação na produção acaba por gerar ganhos de produtividade (JORGE, SOARES e NARETTO, 1993).

Assim, a reciclagem ao proporcionar a utilização mais eficiente dos insumos utilizados e ao estimular o reaproveitamento de materiais que já foram produzidos, provoca uma redução nos custos arcados pela produção. 
Segundo Kalecki (1977), toda a valoração produtiva do que antes era considerado resíduo passa a ser uma fonte de crescimento, com baixo investimento. A prolongação da vida útil de um material, que já é patrimônio, reduz a taxa real de depreciação na economia, uma fonte de crescimento de baixo custo.

A depreciação significa a redução do preço ou do valor atribuído a um bem. $O$ valor atribuído a este bem depende da utilidade que este bem pode proporcionar. A reciclagem, ao aumentar a utilidade do investimento já realizado gera ganhos econômicos e passa a ser adotada como uma estratégia empresarial de redução de custos.

Assim a logística reversa ${ }^{5}$, que inicialmente era utilizada em grande escala pela indústria de bebidas, e ainda é no caso da indústria de cerveja, que utiliza em parte da produção garrafas retornáveis, passa a ser desenvolvida como estratégia industrial em muitos setores industriais.

Entretanto, a logística reversa implica em custos, pois os produtos que poderiam ser reaproveitados, pós-consumo, estão dispersos pela cidade, o que provoca um alto gasto com o transporte.

Nos países desenvolvidos a atuação do Estado para um gerenciamento adequado dos resíduos sólidos urbanos, que responsabiliza os produtores e consumidores de recicláveis, e a atuação das empresas de certificação ambiental, que estimulam a adoção de processos produtivos tecnologicamente mais limpos, aumentando os indices de reciclagem na produção, fazem com que os custos arcados com a logística reversa sejam compensados pela incorporação da variável ambiental nas decisões privadas da produção e do consumo.

Já, no Brasil, a falta desta legislação ambiental faz com que para a indústria não se justifique o dispêndio necessário para trazer de volta os produtos descartados pós-consumo.

Além disso, segundo Serôa da Motta e Sayago (1998) colabora para isto $o$ fato de que as indústrias que poderiam aumentar a utilização

\footnotetext{
${ }^{5}$ A logística compreende as atividades de transporte e distribuição dos produtos pelas empresas. A logística reversa cuida do transporte e do retorno às empresas dos produtos descartados pósconsumo.
} 
de recicláveis realizam também a extração da matéria-prima. Assim, a incorporação da reciclagem ocorre mais facilmente quando os custos de extração da matéria-prima são altos o suficiente para justificar o dispêndio realizado com a logística reversa.

Assim, o elo existente entre os altos indices de reciclagem e a falta de uma legislação ambiental para um gerenciamento adequado dos resíduos é feito pelo trabalho precário e desvalorizado realizado pelos catadores e intermediários no setor informal da reciclagem, já que eles arcam com os gastos necessários para o transporte e beneficiamento dos materiais.

Este fato permitiu a formação de uma estrutura consolidada de trabalhadores no setor informal da reciclagem, no Brasil.

\subsubsection{Estrutura do mercado informal de reciclagem, no Brasil}

- mercado informal de reciclagem possui características específicas, com um forte desequilíbrio entre a oferta e a demanda. É um mercado oligopsônico ${ }^{6}$, ou seja, formado por poucos compradores que por possuírem forte influência conseguem estipular o preço $e$ a quantidade dos materiais a serem reaproveitados. (SEROA da MOTTA e SAYAGO, 1998).

A oferta de materiais recicláveis é abundante devido à crescente geração de resíduos que é provocada: pela mudança nos hábitos de consumo da população, que passou a consumir uma maior quantidade de produtos industrializados; pela concentração urbana; e pela falta de uma legislação ambiental que regulamente as atividades de reciclagem.

Apesar desta oferta de materiais recicláveis ser abundante ela está dispersa, o que não induz a uma concentração de mercado suficiente para atrair os investimentos do capital organizado. Assim, este espaço intersticial da economia é ocupado pelo crescente número de

\footnotetext{
${ }^{6}$ No oligopólio o mercado é formado por poucos vendedores. Em um oligopsônio ocorre o inverso, são poucos compradores.
} 
desempregados e auto-empregados, que realizam o trabalho de catação urbana.

Estes trabalhadores estão organizados no setor informal da reciclagem e atendem à demanda industrial por recicláveis.

Em contraposição ao montante da oferta, a demanda por materiais recicláveis é constituída por poucos compradores e é segmentada em setores que podem ser divididos em dois grupos: o setor industrial e o setor intermediário.

No setor industrial, a falta de uma política ambiental de minimização de resíduos que regulamente o setor da reciclagem, faz com que apenas uma parcela das indústrias, com interesse econômico e comercial, realize a demanda por materiais recicláveis.

Além disso, grande parte da demanda industrial por recicláveis é realizada por empresas que também realizam a extração da matériaprima virgem, o que deixa este setor livre para estipular os níveis de recicláveis a serem reincorporados. É a demanda industrial que determina e regula as atividades, informais ou não, de reciclagem, incluindo o preço pago aos materiais recuperados. Este preço varia, entre outros fatores, de acordo com o custo de extração da matéria-prima. Quanto mais alto for este custo, maior o valor atribuído ao material recuperado (SERÓA da MOTTA e SAYAGO, 1998).

Já, o setor intermediário da demanda por recicláveis é formado por trabalhadores que possuem determinados bens de capital, necessários tanto para o beneficiamento quanto para o armazenamento, garantindo as condiçōes de quantidade e qualidade do material, estabelecidas pela indústria recicladora.

Este setor também possui características oligopsônicas, devido aos altos custos de triagem e beneficiamento dos materiais, que funcionam como uma barreira de entrada para outros concorrentes e, devido à pequena escala na produção dos materiais recicláveis, que restringe a atuação para agentes que possuam determinada quantidade de capital disponivel (SERÓA da MOTTA e SAYAGO, 1998). 
Muitos destes trabalhadores intermediários também atuam na informalidade e apesar de possuirem um montante de capital também realizam um trabalho precário.

Os catadores de materiais recicláveis atuam no início desta cadeia informal, já estruturada, para o beneficiamento e reaproveitamento de materiais descartados e subtilizados.

Entretanto, um dos efeitos da crescente valorização da questão ambiental é que ela promove um aumento nas atividades de reciclagem e as grandes empresas organizadas são atraidas para investir nestes pequenos espaços económicos expulsando as atividades realizadas, até então, pelos catadores.

Para identificar a situaçăo destes trabalhadores informais catadores e intermediários - nas decisőes estratégicas das indústrias de aumentar os indices de recicláveis, segue uma descrição sobre a indústria do alumínio e do papel. Estes dois setores foram selecionados, entre outros, devido ao alto valor pago pelo alumínio e pela representatividade da quantidade de papel, na composiçăo dos materiais coletados pelos catadores.

\subsubsection{A Indústria de Alumínio no Brasil}

A incorporaçăo do alumínio nos processos industriais é recente, quando comparada à incorporação de outros minérios, pois o alumínio não é encontrado em estado natural, mas através de processos químicos que são aplicados sobre a bauxita (minério de alumínio). Assim, o alumínio só foi isolado em 1824 , e a primeira obtençăo industrial foi realizada em 1854, através de um lingote de metal, que despertou a atençăo por ser muito mais leve do que o ferro (ABAL, 2003).

A produção de alumínio primário envolve as seguintes etapas: extração da bauxita, produção de alumina, a redução que resulta no alumínio líquido e a etapa final de fundiçăo do metal (BNDES, 1998). 
De acordo com estudo realizado por Britto (1993), até a década de 70 , a indústria do alumínio era formada por um oligopólio dos "seis grandes produtores": Alcoa, Kaiser, Reynolds, Alcan, Pechiney e Alusuisse.

Entretanto, devido ao fato de que o principal custo para a produção de alumínio é a eletricidade, que representa $40 \%$ do custo de produçăo do metal, a partir de 1974, com as crises de petróleo, ocorreu uma mudança na estrutura da produçăo mundial. As grandes empresas se descentralizaram e, como estratégia para reduçăo de custos, abriram oportunidades para o desenvolvimento da produçăo nos países ricos em recursos naturais, especialmente a bauxita, e em recursos energéticos.

Assim, passaram a atuar no mercado mundial de alumínio alguns produtores dos países em desenvolvimento, caso do Brasil, da Venezuela e do Oriente Médio.

Atualmente, o Brasil é um dos principais produtores e exportadores de alumínio primário do mundo. Suas extensas reservas de bauxita, localizadas no norte do pais, e o seu potencial hidrelétrico consolidaram a atuação do país no cenário mundial de alumínio.

Segundo informaçōes da Associaçăo Brasileira de Alumínio ABAL (2003), pelo histórico da produçăo de alumínio podemos verificar a atuaçăo das principais empresas produtoras de alumínio primário, no país.

A Elquisa - Eletro Química Brasileira S/A, de Ouro Preto (MG) contou com o apoio do Governo Vargas para a produção do metal. Em 1944, realizou as primeiras atividades de extraçăo de bauxita em escala industrial, e, na época, concorria com a CBA - Companhia Brasileira de Alumínio, de Mairinque (SP).

A Companhia Brasileira de Alumínio - CBA foi fundada em 1941, e contava com as reservas de bauxita de Poços de Caldas, mas sua unidade industrial para a produção de alumínio primário acabou sendo localizada na área de Rodovelho, próxima de Sorocaba, onde a disponibilidade de energia elétrica e o combustivel (lenha) eram mais 
abundantes. A empresa paulista foi uma das pioneiras, que permanece até hoje.

A Elquisa foi adquirida pela Aluminium Limited do Canadá - Alcan, em junho de 1950. A Alcan tornou-se a primeira multinacional a atuar no Brasil para a produção de alumínio, produzindo não só alumínio primário, mas produtos transformados do alumínio.

A Alcoa - Aluminium Company of America, empresa líder americana do setor, estabeleceu representação no Brasil em 1915, mas iniciou suas operações comerciais somente em 1940, voltando a se interessar pelo mercado brasileiro no início da década de 60, quando adquiriu a Companhia Geral de Minas, detentora de jazidas de bauxita, em Poços de Caldas (MG).

A instalação da primeira unidade de redução de alumínio da Alcoa, em Minas Gerais, destinava-se a produzir alumínio para o mercado interno, no período entre 1967 e 1970, o que coincidiu com a descoberta das grandes reservas comerciais de bauxita da Amazônia, feita pela Alcan, em 1967.

Após a descoberta destas reservas de bauxita no norte do país a produção nacional se expandiu, principalmente na década de 80 .

A Valesul Alumínio S.A. passou a operar em 1982, por iniciativa da Companhia Vale do Rio Doce - CVRD, e está entre as iniciativas do Estado para incentivar a produção de alumínio, numa ação conjunta com a Billinton Metais S.A., subsidiária do Grupo Shell. A produção realizada pela Valesul permitiu substituir as importações de alumínio, realizadas na época.

A Billinton junto com a Alcoa deram início, em 1984, ao Consórcio Alumínio do Maranhão - Alumar, para a produção de alumina destinada à exportação de alumínio primário, realizada em grande escala.

Seguindo a mesma estratégia de exportação de alumínio primário, a CVRD deu andamento ao projeto Albrás, num consórcio com a NAAC Nippon Amazon Aluminium Co. Ltda., que teve início em 1985. 
Cabe ressaltar que a Albrás e a Alumar são projetos voltados para o mercado exterior, e que a Valesul, em Campo Grande, foi instalada para atender o mercado consumidor da região centro-sul.

Assim, para a produção de alumínio primário, são 5 produtores atuam no mercado brasileiro: Alcoa, Alcan, Billinton, CBA e a Aluvale, que compreende a participação da CVRD na Albrás e na Valesul. A produção de alumínio primário é basicamente voltada para a exportação. A CBA, Alcoa e Alcan são empresas verticalizadas, que atuam desde a extraçăo de matéria prima até a produção de produtos manufaturados de alumínio, enquanto que a Billinton e a Aluvale não diversificaram sua produção, concentrando-se na extração de matéria-prima (BRITTO, 1993).

Com a entrada de novos produtores no mercado mundial de alumínio, ocorreu uma redução no preço do alumínio primário. Assim, para agregar valor à produção, as grandes empresas mundiais de alumínio passam a investir em tecnologias para produzir produtos manufaturados de alumínio.

Isto favoreceu o desenvolvimento dos transformados de alumínio, que envolve as seguintes atividades: a extrusão, cujo principal cliente é o setor da construção civil; a laminação, com a produção de embalagens e bens de consumo; e a fundição, com produtos, principalmente, para a indústria automobilistica, como rodas e radiadores (BRITTO, 1993).

A diversificação dos produtos representa uma estratégia de competição tecnológica dentro da indústria, especialmente nas áreas de laminação e fundição. No caso da laminação, o crescimento da participação do alumínio advém de melhorias significativas que possibilitaram a produção de folhas mais finas, o que permitiu a incorporação do alumínio na produção de embalagens, especialmente para bebidas.

Entretanto, o Brasil não possui grande atuação no setor de transformados. Este fraco desempenho é justificado pelas características do parque industrial, formado por grandes empresas que exportam o alumínio primário. 


\subsubsection{Reciclagem de Alumínio}

O desenvolvimento de novas tecnologias no setor de transformados de alumínio permitiu tornar mais competitivo o aproveitamento da sucata, pela reciclagem. A utilizaçăo do alumínio secundário ou reutilizado, pelas atividades de refusão, é uma tendência que se consolida na indústria.

Segundo Britto (1993), são duas as fontes para a reciclagem de alumínio, a sucata industrial, que representa cerca de $12 \%$ do total da sucata, e a sucata de obsolescência, pelo reaproveitamento de materiais pós-consumo.

"A reciclagem dos produtos pós-consumo envolve os seguintes ciclos: coleta de materiais realizada pelos catadores, com a pesagem em centros de recolhimento e a transferência destes materiais para refusores independentes que farăo a briquetagem, refusăo e transformaçăo do alumínio secundário em um novo lingote, e a transferência deste lingote para os produtores de transformados de alumínio" (BRITTO, 1993, p. 77).

Qualquer produto feito em aluminio pode ser reciclado infinitas vezes, sem perder suas qualidades no processo de reaproveitamento, ao contrário de outros materiais. A reciclagem varia de acordo com a vida útil do produto. $O$ setor de embalagens, especialmente o de latas de bebidas, devido ao seu curto ciclo de vida, apresenta um elevado potencial para utilizaçăo de recicláveis.

O dinamismo apresentado, no Brasil, para o setor de reciclagem de latas de alumínio pode ser atribuído, em grande parte, a Reynolds Latasa, instalada, em 1990, para a produçăo de latas de bebidas (BRITTO, 1993).

Em 2002, O Brasil reciclou 253.500 toneladas de aluminio, equivalente a $35 \%$ do consumo doméstico, ficando acima da média mundial de $33 \%$. Além disso, o pais lidera a reciclagem de latas de alumínio, tendo alcançado o índice de $87 \%$ do total produzido, mantendose como campeão na reciclagem de latas de alumínio, entre os países onde esta atividade não é obrigatória por lei (ABAL, 2003). 
O que justifica o sucesso do programa de reciclagem desenvolvido pela Latasa, é o alto valor do alumínio no mercado, atraindo para a atividade de catação pessoas que buscam fontes alternativas de renda e, também, o desenvolvimento de programas que estimulam a participação da sociedade civil, através de parcerias com escolas, clubes, comércio, shoppings e supermercados, além de entidades beneficentes, num eficiente sistema de estimulo à coleta dos recicláveis (BRITTO, 1993).

Ainda segundo Britto (1993), a proximidade dos produtores de semimanufaurados e transformados em relação aos refusores, o preço pago nos centros de recolhimento aos catadores e a capacitação dos refusores na qualidade do lingote secundário, garantem o alto nível de reciclagem de alumínio, no Brasil.

Além disso, a produção de aluminio secundário possibilita: menor custo de produçăo, com uma reduçăo entre 80 e $85 \%$ em relaçăo a produçăo de um lingote de alumínio primário; menor consumo de energia, representando apenas $5 \%$ do gasto necessário para a produção de um lingote de alumínio primário; a possibilidade das empresas utilizarem escalas de produção mais reduzidas; além da reduçăo nos custos ambientais, já que para cada $1.000 \mathrm{~kg}$ de alumínio reciclado são poupadas cerca de $5.000 \mathrm{~kg}$ de bauxita. (BRITTO, 1993).

Segundo a ABAL (2003), em 2002, a reciclagem de latas de alumínio proporcionou a economia de cerca de $1.700 \mathrm{GWh} / \mathrm{ano}$, o que corresponde a $0,5 \%$ de toda a energia gerada no país. A reciclagem de alumínio, no Brasil, envolve perto de 2.000 empresas e movimenta $\mathbf{R} \$$ 850 milhőes por ano. Estima-se que mais de 150 mil pessoas vivem exclusivamente da coleta de latas de alumínio no país.

Entretanto, segundo Britto (1993), apesar da qualidade do produto gerado pelos refusores, este setor apresenta uma produção quase artesanal, de pequena escala e baixo nivel de capitalização, provocando um gargalo técnico nas atividades de refusão. Este problema, que representa um entrave para o aumento das atividades de reciclagem de alumínio, pode ser solucionado por duas alternativas. 
A primeira é a diversificação dos grandes produtores de alumínio que passariam a atuar também nas atividades de refusão. Esta alternativa já é analisada e defendida por alguns empresários, através de projetos de implantação de uma planta-modelo para a fundição de lingotes secundários. A segunda alternativa é a redução no número de refusores, pela seleção de mercado, através da concorrência dos mais eficientes, centralizando a atividade nas mãos de algo em torno de quatro unidades, melhores capacitadas.

Assim, pode-se perceber que na cadeia de reciclagem, já consolidada pela indústria de alumínio, o espaço de atuação utilizado pelos catadores depende e é subordinado às decisões estratégicas adotadas pelas grandes empresas.

Nas alternativas, citadas por Britto (1993), para melhorar e atenuar - gargalo existente nas atividades de refusão, pela segunda alternativa, a seleção e capacitação dos refusores pelo mercado, ainda fica garantido o espaço de atuaçăo para os catadores, que poderão continuar realizando a coleta dos materiais, entretanto, pela primeira alternativa, com a consolidaçăo de sistemas mais eficientes de coleta, que interliguem diretamente o consumidor aos centros de recolhimento, o espaço de intermediação feito pelos catadores, até então garantido, é eliminado.

Programas para esta aproximaçăo na relaçăo do consumidor com a logística reversa realizada pelas empresas já são desenvolvidos, e em alguns shoppings e escolas estão instalados os "papa-latas", equipamentos onde os consumidores depositam diretamente a embalagem pós-consumo, que săo recolhidas pelos transformadores de alumínio.

Cabe lembrar que entre as sugestőes citadas por Britto (1993) para reestruturar as atividades de refusão de alumínio estão: 0 apoio institucional através de capacitação tecnológica para estes refusores; programas educacionais para promover a reciclagem; e a aglutinação dos refusores independentes numa escala maior, podendo-se recorrer para isso à concessão de linhas de crédito especiais. 


\subsubsection{A Indústria de Papel no Brasil}

A produção do papel ocorre pela transformação de uma mistura de material fibroso e cargas minerais, que definem as características de coesão às fibras. Esta mistura dá origem a uma massa que é lançada nas máquinas, num formato de telas, para a formação da folha de papel. 0 que varia na diferenciação dos papéis produzidos são as especificaçōes sobre gramatura, resistência, maciez e permeabilidade que se deseja. 0 processo de formação ocorre em meio aquoso, necessário à consolidação das tramas das fibras. Em seguida, as máquinas realizam o processo de secagem e ao final se obtém o papel (JORGE, SOARES e NARETTO, 1993).

As diversas possibilidades de combinação entre as fibras, e entre os materiais adicionados, originam uma variedade de produtos finais, que podem ser divididos em 6 segmentos: papel de imprensa; papel de imprimir e escrever; papéis de embalagens; papéis para fins sanitários (tissue); papéis cartões e papéis especiais (JORGE, SOARES e NARETTO, 1993; BNDES, 2000b).

Os papéis mais produzidos são os de imprimir e escrever; de embalagem e os papéis cartões (BNDES, 2000b).

Baseado no estudo de Jorge, Soares e Naretto (1993), segue uma descriçăo para estes segmentos da produção de papel.

$\checkmark$ Os papéis de imprensa são utilizados na confecção de jornais. São produzidos em unidades de grande escala e este segmento tem utilização crescente de recicláveis.

$\checkmark$ Os papéis de imprimir e escrever são divididos em papéis revestidos e não revestidos. Os papéis não revestidos são utilizados na xerografia, livros e cadernos. Os papéis revestidos são mais sofisticados e caros e seus principais consumidores estão na área de publicidade e editoraçăo, para as revista e livros, por exemplo.

$\checkmark$ Para o segmento de embalagens, os principais produtos são: o kraft, de grande resistência ao tracionamento, utilizado na produção de sacos multifoliados nas embalagens de fertilizantes; o papelão 
ondulado, confeccionado com duas camadas de papel plano (capas) e uma de papelăo ondulado; $\theta$ os produtos leves como envelopes. A utilizaçăo de reciclados neste segmento é crescente.

$\checkmark$ Os papéis para fins sanitários (tissue) englobam os papéis higiénicos, lenços e toalhas de papel. A produçăo neste segmento, geralmente, é restrita ao mercado local devido ao baixo volume do produto que encarece o transporte à longa distância.

$\checkmark$ Os papéis cartões são utilizados em grande parte para as embalagens finais dos produtos. Assim como os papéis para fins sanitários, sua produção năo pode ser globalizada devido à necessidade de um relacionamento especifico com os clientes para atender a especificidades no produto final. Este setor está fortemente ligado às gráficas. Os principais clientes são as indústrias: alimentícia, de higiene e limpeza, calçados, fumo e farmacêutica.

$\checkmark$ E o último segmento, de papéis especiais, que inclui: papéis térmicos para fax; de segurança, como o papel moeda, cheque, passagem aérea, bilhete de loteria e metró; decorativos como o papel vergé, colorido e heliográfico; papéis para a indústria de fumo, como o papel para o cigarro e ponteiras; para automóveis, no revestimento de portas, filtros de ar, juntas e separador de baterias; calçados, em betumados; e laminados, utilizado em base para fórmicas.

A indústria de papel, como um todo, passa por mudanças na concorréncia internacional. Por ser uma indústria madura e consolidada concentra suas estratégias competitivas na integração produtiva, pelas fusōes e aquisiçōes entre as empresas de diferentes segmentos e na especialização da produção, seja no desenvolvimento de novos produtos, seja no aumento da escala produtiva. Além disso, a incorporação da variável ambiental transformou-se num elemento de diferenciação de produtos para esta indústria.

"A exigência de qualidade transcende ao produto em si e atinge o processo produtivo e as etapas anteriores e posteriores à produção, com 
a exigência do Certificado de Garantia e Qualidade, segundo as normas da séria ISO 9000" (JORGE, SOARES e NARETTO; 1993, p. 28).

Os principais insumos para a indústria de papel são a celulose, baseada na utilização de bases florestais, a energia e a água. Para atender ao controle ambiental, a indústria passou a utilizar melhor estes insumos.

Ganha ênfase a realização de processos produtivos fechados, com - máximo reaproveitamento de efluentes gerados, que implica, por exemplo, na diminuição da perda de fibras durante o processo de secagem, e na reutilização e tratamento dos efluentes líquidos, adotandose sistemas de condensação do licor negro, pela instalação de caldeiras de recuperação e filtros, que proporcionam a redução no desperdício de água.

No caso da utilização mais eficiente de energia, os produtores integrados, ou seja, aqueles que produzem desde a base florestal até as bobinas de papel, têm reforçado a possibilidade de utilização de vapor, madeira (lenha ou restos de picagem) e carvão vegetal para alimentar as caldeiras e também, caso exista recursos hídricos, a auto-geração de eletricidade.

Para o aprimoramento na utilização de celulose, grande parte da pesquisa tecnológica é aplicada nas atividades florestais, com 0 aprimoramento genético das plantas. A melhoria na utilização das fibras reduz a dependência no fornecimento de fibra virgem, no caso a celulose, fazendo avançar o uso de fibras de base florestal replantada, de papel reciclável e de mistura de fibras.

Foi no desenvolvimento de novas fibras para a produção de papel que o Brasil consolidou sua participação no mercado internacional. A pesquisa e a tecnologia para utilizar as fibras curtas, provenientes das plantações de eucalipto, foram financiadas pelo Estado, através de recursos do BNDES e envolveu diversos setores de pesquisa como a Embrapa, o IPT e a ESALQ - USP. Além disso, a entrada de capital estrangeiro provocou a integração entre as indústrias nacionais e 
estrangeiras, favorecendo a incorporação desta fibra pelo mercado internacional (JORGE, SOARES e NARETTO; 1993).

A utilizaçăo de fibras longas provenientes de plantação de pinus tinha participação hegemônica na produção de papel. Entretanto, a valorização da questăo ambiental implicou em custos crescentes para a utilizaçăo desta madeira. Neste cenário, a principal vantagem competitiva do Brasil é a sua tecnologia florestal, que pelo desenvolvimento genético do eucalipto permite o corte para a industrializaçăo em apenas 7 anos, com alta produtividade (BNDES, 1996).

Para o ano de 1995, a utilização de fibra curta de eucalipto foi de $45 \%$ na produção mundial de celulose de mercado ${ }^{7}$ (BNDES, s.d.).

Assim, o Brasil, que até 1978 era importador de papel e celulose, passa a ter uma importante atuação no cenário mundial. A produção nacional de celulose de mercado é composta essencialmente de fibra curta branqueada de eucalipto voltada, essencialmente, para o mercado externo. A Aracruz exerce a liderança, concorrendo com a Bahia Sul e a Cenibra. Neste setor ganha participaçăo na concorrência internacional a produçăo dos paises asiáticos (BNDES, s.d.).

A ampla atuação do Estado para o desenvolvimento da produção de celulose visava, sobretudo a substituição de importaçōes, visto que a produçăo nacional não conseguia atender ao consumo interno. Este apoio propiciou o desenvolvimento da indústria de papel, năo só na produção de celulose, mas também nos diversos segmentos da produçăo de papel, pela atuação de indústrias nacionais e pela entrada no mercado interno de empresas estrangeiras. Atualmente, diversas empresas atuam nos diferentes segmentos de papel e conseguem atender, em grande parte, a demanda interna.

\footnotetext{
${ }^{7}$ No caso da celulose, a produção é dividida entre a celulose produzida para o consumo interno na empresa e a celulose para a venda, no caso a celulose de mercado.
} 
Para o ano de 1999, no Brasil, os principais produtores para papel e celulose, por percentual no total da produção, foram: Klabin (15\%); Cia Suzano (11\%): Champion ( $8 \%$ ); Votorantim $(8 \%)$; Igaras $(6 \%)$; Ripasa (6\%); Rigesa (4\%); Orsa (3\%); Trombini (3\%) e Pisa (3\%). Para o mesmo ano, a distribuiçăo na produçăo para os diferentes segmentos do setor de papel, de acordo com a capacidade de produção, foi: papel de imprensa (3,3\%); Imprimir e Escrever (28,2\%); Embalagem (41,1\%); Papéis Sanitários (9,9\%); Papéis Cartões (14,4\%), e Papéis Especiais $(2,8 \%)$ (BNDES, 2000a).

Segundo informações de Jorge, Soares e Naretto (1993) e do BNDES (2000a), segue a descrição da produção nacional nos seis segmentos da produção de papel:

$\checkmark$ No segmento de papéis de imprensa os maiores produtores são a Klabin e a Pisa, esta controlada pelo grupo O Estado de S.Paulo, ambas localizadas no estado do Paraná, com a produção baseada em fibra longa. Neste segmento quase a metade do consumo interno é importada, especialmente do Canadá e Finlândia.

$\checkmark$ Para os papéis de imprimir e escrever, a concorrência se dá entre a norte-americana Champion, Cia. Suzano - Bahia-Sul, a Ripasa e a Votorantim. Neste tipo de papel a fixação da marca junto ao público é uma estratégia importante adotada pelas empresas. A Champion produz o Chamex, a Cia. Suzano o Report, a Votorantim o Copimax e a Ripasa produz o Ripax. A produção é concentrada nas regiōes Sudeste (75\%); Sul (14\%) e Nordeste (10\%).

$\checkmark$ No segmento de embalagens, os principais produtores são a Klabin (nacional), a lgaras (subsidiária da Riverwood - EUA), a Rigesa (pertencente ao grupo Westvaco - EUA) a Orsa e a nacional Trombini. Na produçăo de papelão ondulado, em que é utilizado um elevado percentual de recicláveis, a Klabin, a Igaras e a Rigesa possuem instalaçōes no estado de São Paulo, e a Trombini, no Paraná, Rio Grande do Sul e Minas Gerais. 
$\checkmark$ A produção de papéis sanitários é mais pulverizada do que nos outros segmentos, existindo cerca de $\mathbf{4 0}$ fabricantes. Entretanto as 5 maiores empresas responderam, em 1999 , por $53 \%$ da capacidade instalada. São elas: a Klabin - Kimberly, com instalações nos Estados da Bahia, Pernambuco, Rio de Janeiro, Santa Catarina e São Paulo; a Santher, com instalações em Minas Gerais, Săo Paulo e Rio Grande do Sul; a Melhoramentos, localizada em São Paulo; a Minikraft, também localizada em São Paulo; e a Mili, em Santa Catarina.

$\checkmark \mathrm{Na}$ produção de papéis cartőes as líderes deste segmento são: a Klabin, a Cia. Suzano, a Ripasa, a Papirus e a Itapagé. A região sudeste concentrava $70 \%$ do total produzido, seguida pela região sul, com 27\%, no ano de 1999. Cabe ressaltar também a atuação da Papirus, que não possui a produção integrada com uma base florestal e por isso apresenta uma grande utilizaçăo de recicláveis, com um alto padrão tecnológico.

$\checkmark$ O segmento de papéis especiais possui uma reduzida escala na produção nacional, conseqüência da dificuldade no acesso às tecnologias requeridas.

\subsubsection{Reciclagem do papel}

A pressão pela utilização de papel reciclável é crescente na indústria de papel. A legislação dos países avançados, especialmente os países da União Européia, tem obrigado ao uso de percentagens crescentes de reciclados na composiçăo do papel.

Nestes paises, uma legislação que obriga a utilizaçăo de niveis mínimos de recicláveis, resulta no estabelecimento de novos padrões de consumo, com a aceitaçăo de papéis com menor alvura. São utilizados dois indicadores para medir o índice de reciclagem: a taxa de utilização de reciclados, medida pelo consumo de matéria-prima em relaçăo à produçăo total de papel; e a taxa de recuperação ou coleta, medida pelo 
papel reutilizado em relação ao total consumido de papel (JORGE, SOARES e NARETTO; 1993).

Esta incorporação da variável ambiental para a realização de processos produtivos e de produtos com elevado padrão de qualidade se aplica também na relação destes países com seus consumidores. Assim, a variável ambiental se concretiza como um dos fatores para 0 acirramento da concorrência entre as empresas.

Os contratos internacionais passam a requerer certificados de garantia de qualidade segundo as normas da International Standard Organization -ISO.

A exigência do certificado de qualidade ISO - 9000 , e a adoção do "selo verde" pela Comunidade Européia representam um efetivo instrumento de marketing para os produtores que possuem o perfil determinado. (JORGE, SOARES e NARETTO; 1993).

$O$ uso crescente de fibras recicladas se faz nos segmentos de papel de imprensa, no segmento de embalagens, especialmente para o papelão ondulado na produção do miolo e também da capa, na produção de papéis sanitários e no segmento de papel-cartão.

Para atender a exigência estabelecida pelos seus principais consumidores, a indústria de papel no Brasil procura aumentar a utilização de recicláveis na sua produção.

Segundo Jorge, Soares e Naretto (1993) para aumentar a oferta de recicláveis, as estratégias devem envolver a criação de uma cultura de reciclagem, que deve fazer parte dos programas escolares básicos e de campanhas institucionais, na mídia, tendo como tema o desperdício e a reciclagem, que poderia ser estimulada, a curto prazo, por sistemas de reembolso financeiro, ou por campanhas de retorno comunitário, como por exemplo, ter a renda revertida a hospitais e instituiçōes filantrópicas. A longo prazo, cabe normalizar e reordenar a relação e os interesses de usuários e fornecedores, inclusive pela negociação de contratos de fornecimento de médio prazo, com preço estável, podendo também ser articuladas associações para a criação de estoques reguladores e 
cooperativas de compra, venda e distribuição (JORGE, SOARES e NARETTO; 1993).

A aproximação da indústria de papel com as cooperativas de catadores para a compra de papéis recicláveis já é adotada pela Cia. Suzano que compra materiais diretamente da Coopamare, situada no bairro de Pinheiros, em São Paulo.

\subsubsection{A reciclagem como estratégica de reduçăo de custos}

A crescente valorização da questão ambiental pela sociedade como um todo, à medida que muda os padrōes sociais e o conceito de bem-estar, que passa a incluir a preservação dos recursos naturais, provoca também uma mudança nos planos estratégicos das indústrias.

Como pôde ser observado, no Brasil, a reciclagem no processo produtivo ocorre por dois motivos: ou pela viabilidade econômica, quando os custos de extração dos recursos naturais săo elevados e o reaproveitamento dos materiais é um importante instrumento de reduçăo nos custos, como no caso da indústria de alumínio, ou pelo acirramento na competição que leva a indústria a incorporar a variável ambiental como um dos elementos de diferenciação dos produtos, como no caso da indústria de papel.

Entretanto, as decisões estratégicas das empresas em realizar a reciclagem incluem apenas os benefícios privados do reaproveitamento. $\dot{E}$ a valorização econômica da reciclagem.

Esta situação, num cenário mais competitivo entre as indústrias, em que a variável ambiental começa a ser utilizada como um elemento a mais para a competição, exigindo maior eficiência na utilização de recicláveis, provoca a atração de setores com maior poder de investimento para os espaços econômicos até então utilizados pelos catadores. 
Como visto, a indústria de alumínio já estuda a possibilidade de realizar o intermédio direto entre os seus consumidores para trazer de volta para a produção os produtos descartados pós-consumo.

No entanto, a falta de um gerenciamento adequado para os resíduos sólidos urbanos, por parte do Estado, permite que as atividades de reciclagem sejam realizadas apenas de acordo com 0 interesse privado no reaproveitamento.

Além disso, o enfoque na reciclagem desvirtua a discussão realizada por algumas correntes ambientalistas baseada nos $3 R s$, ou seja, primeiro a redução nos resíduos, depois a reutilização e após estas etapas a reciclagem.

A adoção de políticas ambientais, que regulamentem e responsabilize os produtores e consumidores de recicláveis, è fundamental para direcionar as mudanças no comportamento dos agentes econômicos, possibilitando com isso a mudança nos padrões dos produtos a serem consumidos.

A crescente geração de resíduos envolve a utilização de bens públicos: os recursos naturais e a sua degradaçăo. Assim, a intervençăo estatal é necessária para a convergência nos interesses, tanto do setor industrial, quanto da sociedade civil e também dos trabalhadores informais da reciclagem. 


\subsection{Bens ambientais e Resíduos Sóludos Urbanos}

\subsubsection{Bem Público e Custos Sociars Da Degradação Ambiental}

A crescente geração de resíduos sólidos urbanos e suas formas decorrentes de tratamento e disposiçăo final estão incluidas na questão ambiental, visto que envolvem a extração de recursos naturais, matérias primas e energia, e a degradaçăo destes recursos pela emissão de rejeitos e de poluição.

Os resíduos sólidos tém origem tanto nas atividades de produção quanto nas de consumo, que englobam cada vez mais a utilização de materiais de vida útil reduzida, aumentando a geraçăo per capita e a produçăo de materiais de dificil decomposiçăo. Sua soluçăo trata-se de uma discussão multidisciplinar, que inclui aspectos ambientais, sociais, técnicos, econômicos e de saúde.

A geraçăo de lixo e o não reaproveitamento, quando possivel, destes materiais, representa um desperdício, pela utilizaçăo ineficiente de recursos. Este desperdício, ao não ser coletado e devidamente tratado torna-se uma fonte poluidora que contamina $o$ ambiente, $o$ ar $e$ as águas, com a geração de chorume e de gases poluentes, com o gás metano, além de criar um ambiente propício à proliferação de vetores transmissores de doenças.

O tratamento e a disposição final adequada dos resíduos sólidos garantem a promoção da saúde pela salubridade ambiental. A promoção da saúde visa garantir a saúde pela mudança das práticas que propiciam doenças, privilegiando as causas antes das conseqüências. No caso dos resíduos, o gerenciamento adequado pela redução na fonte geradora evita a poluiçăo desnecessária, reduzindo seus efeitos danosos e favorecendo a manutenção de um ambiente saudável.

A preservação do meio ambiente e dos recursos ambientais é um serviço de interesse público pelo fato de serem essencial para a coletividade. 
Os bens ambientais possuem características semelhantes a dos bens públicos, como por exemplo, o consumo indivisivel, uma característica que provoca a dificuldade de serem valorados pelo mercado.

O tratamento dos bens públicos, como um bem econômico, difere completamente de um bem privado. $O$ bem privado permite exclusividade no seu consumo e, por isso, a valoraçăo pela manifestação das preferências individuais, via preço. Já o bem público beneficia a todos de igual modo, tendo seu consumo indivisivel e năo excludente, ou seja, são consumidos por diversas pessoas ao mesmo tempo e o consumo por uma pessoa năo interfere no consumo dos demais.

Por ser de livre acesso, o consumidor tende a subestimar o valor dos bens públicos, de forma que se existisse um mercado, o preço destes bens năo seria muito diferente de zero (CONTADOR, 2000).

Para os bens ambientais, a incerteza dos efeitos produzidos pela degradação pode interferir tanto na decisão de consumo atual, quanto no direito de consumo de outros agentes, como por exemplo, o das gerações futuras.

A diferença essencial entre o bem ambiental e o bem público, é que o consumo desmesurado do bem ambiental leva a sua extinção, o que não ocorre no caso do bem público. $O$ consumo de um bem ambiental, apesar de não ser exclusivo, ou seja, ser de livre acesso, é um consumo rival, potencializado pelos efeitos da degradaçăo do bem em questão. Esta característica agrava a necessidade de práticas preventivas que mantenham o meio ambiente saudável, evitando a poluiçăo desnecessária (PRESTRE, 2000).

"O problema principal da sociedade é o que ela produz, manifestando uma tendência de provocar uma oferta abundante de certos produtos, os bens privados, e uma oferta insignificante de outros, os bens públicos" (GALBRAITH, 1972, p. 240). 
A mudança no padrão de consumo e o crescente aumento na produçăo de descartáveis e produtos com alta obsolescência, aumenta a geraçăo de resíduos e os custos com os serviços de limpeza urbana.

A geraçăo dos resíduos sólidos urbanos está inserida numa questão complexa para a teoria econômica: quando as atividades originam custos sociais não incorporados.

Ao serem produzidos e consumidos, os produtos e suas embalagens são bens privados, de propriedade particular, mas, ao serem descartados nas ruas e nas calçadas, estes bens inutilizados, passam a representar um custo social, o da degradação ambiental.

"Os custos ambientais geralmente não são captados nas relações de mercado devido à indefiniçăo dos direitos de propriedade. Assim, o custo de degradação não incide sobre os que degradam, mas recaem sobre a sociedade como um todo e sobre as geraçōes futuras" (SEROA DA MOTTA, 1996, p. 82).

Os custos sociais correspondem a todas as perdas, diretas ou indiretas, suportadas por terceiros ou pela sociedade, como resultado do desenvolvimento de atividades que geraram, mas não incorporaram estes custos, pela dificuldade de valoração via mercado. O progressivo aumento dos custos sociais reside, essencialmente, na busca pela minimizaçăo dos custos econômicos. O desequilíbrio existente na remuneraçăo dos custos privados, pagos pela produção, não incorpora os serviços ambientais gratuitos utilizados, nem a degradação provocada, o que origina ao longo do processo uma redistribuição de renda injusta (KAPP, 1966).

As funçōes do Estado possuem três vertentes: promover a eficiência na alocação dos recursos, que inclui a administração e a regulação dos bens públicos; garantir a eqüidade, numa função de redistribuição de renda, por exemplo, através da tributação; e propiciar a estabilidade no desenvolvimento (WONNACOTT e WONNACOTT, 1985). 
No caso dos resíduos sólidos urbanos, a responsabilidade pelo gerenciamento é do município ${ }^{8}$. Desta forma, os encargos financeiros dos custos sociais não incorporados pela produção e pelo consumo, recaem sobre o Estado, que se torna um benevolente comprador.

A degradaçăo ambiental provocada pela crescente geração de resíduos sólidos exige a ação governamental na alocação de recursos públicos para a prestaçăo de serviços públicos de limpeza urbana, entre eles: a coleta, a administração e manutençăo de aterros sanitários, o desenvolvimento de formas alternativas de tratamento e disposição final dos resíduos gerados, os programas de coleta seletiva e a varrição de vias e logradouros públicos.

A falta de uma legislação ambiental, ou de sua efetiva aplicação, que regulamente a responsabilidade na geraçăo dos resíduos sólidos urbanos perpetua esta relação, em que o Estado arca sozinho com os custos da degradaçăo provocada, além de não incentivar a redução na geração de resíduos.

Frente à restrição orçamentária dos órgãos públicos e a crescente importância dada à questão ambiental, a teoria econômica discute formas mais adequadas para a incorporaçăo dos custos sociais no caso dos resíduos sólidos urbanos.

\subsubsection{FORMAS DE INCORPORACÃO DOS CUSTOS SOCIAIS, PELA TEORIA ECONÔMICA}

A economia é a ciência que estuda a utilizaçăo racional de recursos ou meios escassos para atingir fins desejados, ou seja, o bemestar dos indivíduos. O homem não possui a capacidade de criar matéria, mas produz as utilidades inerentes à matéria. Assim a economia aborda a conduta humana como relação entre meios e fins escassos de uso alternativo (KAPP, 1960; MARSHALL, 1982).

\footnotetext{
${ }^{8}$ No caso dos resíduos sólidos comerciais, são de responsabilidade do município os resíduos dos pequenos geradores, nível estabelecido de acordo com cada legislação municipal.
} 
No entanto, a questão ambiental começou a ser incorporada no debate económico apenas quando diversos estudos ressaltaram o problema da degradação ambiental para a continuidade do desenvolvimento.

Em 1968, o Clube de Roma lançou a proposta de crescimento zero. O debate ganhou impulso, em 1972, com a Conferência de Estocolmo, que originou a fundação do Programa das Naçōes Unidas para o Meio Ambiente. Em 1987, a Comissão de Bruntland formulou o conceito de desenvolvimento sustentável e com a Conferência do Rio, em 1992, o debate sobre impor limites ou transformar a produção para evitar a degradação do meio ambiente foi consolidado (AMAZONAS, 1994; TAYRA, 2003).

As duas correntes da teoria econômica aqui analisadas serăo: a corrente neoclássica e a corrente institucionalista. Existem outras correntes que tratam da incorporaçăo da questão ambiental na economia, como a corrente ecológica, que discute a entropia e a questão energética da utilizaçăo dos recursos. Entretanto, as demais correntes não serăo incluídas na análise, visto que o foco central adotado é o papel do Estado nesta temática, que é desenvolvido num rigoroso debate entre neoclássicos e institucionalistas.

A incorporaçăo da questăo ambiental pelos economistas neoclássicos é sustentada na definiçăo do mercado como elemento central de análise. Já os economistas heterodoxos, que inclui as correntes pós-keynesianas, institucionalistas e evolucionistas, tomam como ponto central as instituiçōes $e$ as relações sociais (AMAZONAS, 1994; ROMEIRO e SALLES FILHO, 1996; TAYRA; 2003).

\subsection{Corrente Neoclássica}

A abordagem neoclássica, situada na tradiçăo positivista do conhecimento, que entre outros preceitos metodológicos visa à separaçăo entre sujeito e objeto, procurou passar para as ciências sociais esta construçăo, utilizando para isso uma análise baseada no indivíduo como 
elemento de análise. Pressupōe-se a racionalidade dos agentes econômicos, na busca pelo bem-estar. O ótimo social (ótimo de Paretto) é dado por um ponto de equilibrio onde os individuos têm suas utilidades maximizadas. O mercado, pela política do laissez-faire, é o local onde os indivíduos podem manifestar suas preferências, pela valoraçăo via preço (TAYRA, 2003; KAAP, 1966).

Os custos sociais da degradação ambiental são decorrentes da existência de elementos na natureza que năo permitem a valoração via mercado, ou seja, são externos a este instrumental de análise adotado, denominados de externalidades negativas (PRESTRE, 2000).

Esta dificuldade em valorar os danos ambientais, ou seja, as externalidades negativas, constitui em uma falha de mercado, o que exige a necessidade de intervenção do Estado, um Estado-mínimo para corrigir e mensurar estes valores, já que os neoclássicos reconhecem a existência de diversos valores económicos associados aos bens públicos, entre eles os recursos ambientais, mas que não são incorporados pelo sistema de valoração do mercado.

Desta forma a mensuraçăo, pelo Estado, dos bens ambientais permite que os individuos manifestem suas preferências, agora com a inclusão dos custos antes externalizados. Assim, as instituições têm um papel reduzido, necessário apenas para incorporar os custos sociais, pelos mecanismos de mercado, nas decisões individuais.

Os neoclássicos buscam quantificar estes valores monetários dos bens ambientais por três variáveis: valor de uso, atribuído por aqueles que usam o bem em questão; valor de opção, relativos aos possiveis usos futuros; e valor de existência, que independe de valor de uso presente ou futuro, representado apenas pela necessidade que se atribui à existência do bem (AMAZONAS, 1994; MARQUES e COMUNE, 1996; SEROA DA MOTTA, 1996).

Apesar de aceitarem a controvérsia de que não se pode medir todos os ganhos e perdas ambientais em termos monetários, os neoclássicos destacam algumas vantagens desta mensuração, já que ela 
reflete a avaliaçăo que a sociedade tem do meio ambiente, além do que a precificaçăo dos recursos pode induzir a uma mudança no comportamento, antes poluidor (TAYRA, 2003).

Com os custos sociais incorporados atinge-se um novo ponto de equilibrio. Nota-se que neste ponto não significa que não ocorra poluiçăo ou a degradação ambiental, já que deve haver uma quantidade ótima de poluiçăo, o que contudo, não significa ser zero, pois a própria maximização do bem estar social implicaria num nível mínimo de poluição admitida.

A questão para a preservaçăo ambiental consiste em achar um ponto de equilibrio, após a incorporação nas decisões econômicas dos custos sociais, que iguale os custos marginais de poupar o bem ambiental e o custo marginal da degradação ou poluição do bem em questão. É um processo de barganha entre crescimento econômico e preservação ambiental, uma escolha entre o controle de efluentes e a degradação do bem (SERÓA DA MOTTA, 1996; ROMEIRO e SALLES FILHO, 1996).

"O problema ambiental está em avaliar corretamente os preços dos serviços ambientais para que os agentes económicos sejam corretamente induzidos ao considerarem estes custos. Reconhece-se que a avaliação correta dos preços dos serviços ambientais pelos agentes econômicos, bem como a revelação destes valores (preferéncias), săo complicadas, mas o principal objetivo está garantido, a soberania do consumidor" (ROMEIRO e SALLES FILHO, 1996, pg. 86.).

A principal critica a este estabelecimento via mercado de um nível ótimo de poluiçăo admitida é que não é considerada a dinâmica ecológica do meio ambiente.

Pelo fato de que a inclusão dos custos ambientais se baseia nos mecanismos de mercado esta abordagem concede 0 direito de poluir. Apesar do poluidor ser taxado pela produção gerada, ele tem a possibilidade de continuar poluindo de acordo com as suas preferências individuais. Assim, não é considerada a capacidade de recuperação de um bem ambiental após a sua degradação, e uma vez que esta 
capacidade seja ultrapassada coloca-se em risco a existência deste bem (ROMEIRO e SALLES FILHO, 1996; PRESTRE, 2000).

\subsection{Corrente Institucionalista}

Em oposiçăo à abordagem neoclássica a corrente institucionalista toma como centro de análise as instituiçōes. O mercado é visto como mais uma das formas de instituição existente na sociedade.

"A chamada externalidade é percebida como "externa" apenas caso seja adotada a perspectiva da troca voluntária e centrada no mercado. Se o teórico toma uma perspectiva mais abrangente, vendo os mercados entre as muitas formas institucionais imperfeitas, o que formalmente era visto como externalidade torna-se mais uma forma de comportamento institucionalizado" (LARKIN, 1986 citado por AMAZONAS, 1994, p. 149).

O indivíduo não é encarado como racional nas suas decisões, mas como um elemento em transformaçăo pelo ambiente histórico-socialcultural que o envolve. Desta forma, os valores atribuídos pelos indivíduos são condicionados pela correlação de determinantes que compõe as relaçőes sociais: a ciência, a técnica, os fatores ideológicos e culturais, e não apenas por valores que podem ser traduzidos monetariamente.

O pressuposto teórico da racionalidade do indivíduo na manifestação via mercado de suas preferências reduz a discussão e năo incorpora o fato de que a definição de danos, pelos indivíduos, ocorre após o estabelecimento de padrōes definidos socialmente. Assim, não são as decisões dos indivíduos que precedem o estabelecimento de um padråo, mas um complexo caminho institucional, que define a normalidade e inclui diversas variáveis, como a política, a ciência e a técnica, em uma intrincada definiçăo de valores (AMAZONAS, 1994).

A definição de valores está em constante mudança direcionada pelos avanços científicos e tecnológicos, assim como pela incorporação desta mudança nas instituições. 
Os institucionalistas concordam que o processo político é lento e que as instituiçóes podem ser usadas por determinado grupo dominante. Por isso as definições de padrões podem não ser legitimas, mas também não concordam que são inerentemente viesadas. Contudo, a arena pública pode ser 0 único meio de privilegiar o interesse coletivo sobre os interesses individuais (AMAZONAS, 1994).

As instituições são práticas sociais cristalizadas. Como lembra Romeiro (1999, p. 15.) "as instituiçőes não são nem mesmo criadas para serem socialmente eficientes, mas para servir aos interesses de quem tem poder de barganha para criar regras".

"Por exemplo, na transiçăo do sistema feudal para o capitalismo, a mudança institucional fundamental foi a instituiçăo de direitos de propriedade privada, que veio a abolir as restriçōes relativas a um valor cultural pré-existente, tornando a busca individual do ganho em valor absoluto e, desse modo, transformando-a num fator de transformação decisivo. Agora, a temática ambiental está a exigir uma nova imposição de restriçőes, (...) que não pode se dar pela busca de oportunidades de ganho, mas numa evolução da consciência ecológica, numa mudança do estilo de vida. (...) Esse quadro já deu origem a uma mudança de peso no funcionamento das instituiçōes, provocada pelo crescimento do peso do que se convencionou chamar de terceiro setor, no processo de tomada de decisões" (ROMEIRO, 1999, p. 19-20).

A crescente valoração da questão ambiental resulta destas transformações sociais na definição de valores e no processo de incorporação destes nas instituiçōes. Esta concepção de valor é processual, ou seja, definido a cada passo na resoluçăo dos problemas, o que faz com que apesar de ser progressivo, este valor não necessariamente deixe de ser "míope", pois há valores que são externos também ao ajustamento institucional. 


\subsubsection{INSTRUMENTOS DE COMANDO E CONTROLE E INSTRUMENTOS ECONÔMICOS}

Existem duas ferramentas principais na execução das políticas ambientais: as de comando e controle e os instrumentos econômicos.

No Brasil, assim como na maioria dos paises, a gestão ambiental tem se dado exclusivamente pelo uso da regulaçăo, a partir de normas, ou seja, pelos instrumentos de comando e controle, devido à eficiência no combate aos danos ambientais irreparáveis e à poluição inaceitável (PRESTRE, 2000; SERÓA DA MOTTA, 1996).

As políticas de comando e controle baseiam-se em: limites máximos de contaminação; controles nos equipamentos, com o uso de filtros e penerias; controle sobre o processo para impedir residuos ou substituir insumos; controle sobre produtos, limitando 0 uso de contaminantes; proibição de atividades em determinadas zonas e controle no uso (quotas) de determinados recursos ambientais (TAYRA, 2003).

As principais desvantagens apontadas para a utilizaçăo de políticas de comando e controle săo os altos custos administrativos e a dificil execuçăo, que depende de fiscalização. Esta situação agrava-se com os problemas de recursos orçamentários dos órgăos públicos brasileiros.

Desta forma, a restrição no orçamento público aumenta a necessidade na utilização dos instrumentos econômicos, que não possuem os altos custos das políticas de regulamentaçăo e ainda podem gerar receitas ao Estado.

Os instrumentos econômicos incorporam ao mercado elementos sem preço na natureza, de maneira a tentar internalizar as externalidades. Existem dois tipos de instrumentos: os instrumentos que atuam na forma de prêmios, dando crédito subsidiado, isençōes fiscais e contábeis; e os instrumentos que atuam na forma de preços (SERÓA DA MOTTA, 1996).

"Os incentivos econômicos via preços, orientam os agentes econômicos a valorizarem os bens e serviços ambientais de acordo com sua escassez e seu custo de oportunidade social. Para tal, atua-se na formaçăo dos preços privados destes bens, ou no caso de ausência de 
mercados, criam-se mecanismos que acabem por estabelecer um valor social. Em suma, adota-se o princípio do poluidor/usuário-pagador" (SEROAA DA MOTTA, 1996, p. 86).

Podem ser de tributaçăo direta, taxas e impostos, como taxas ou impostos de emissão, impostos sobre o uso (coleta de lixo); sistemas de depósito-reembolso, para embalagens de bebidas; subsidios para propósitos ambientais, que funcionam como estímulos aos poluidores para a melhoria da qualidade ambiental; ou indireta, licenças e direitos ambientais negociáveis no mercado (TAYRA, 2003).

"A idéia é que estes instrumentos, ao influenciarem, sem restringir, o próprio cálculo econômico dos agentes, obtenham resultados com maior adesão e menores custos" (TAYRA, 2003, p. 107).

A valoração económica permitida pelos instrumentos econômicos prioriza a mudança de comportamento, influenciando os agentes envolvidos a considerarem os custos ambientais e sociais em suas decisões.

Entretanto, os instrumentos econômicos não são eficientes para reduzir a incerteza dos efeitos da degradaçăo ambiental, e assim, para os danos irreparáveis as políticas mais indicadas são as de comando e controle.

$\mathrm{Na}$ prática, ambas as ferramentas, de comando e controle e instrumentos económicos, podem ser adotadas simultaneamente. A importância relativa de cada uma será definida em função das especificidades de cada problema e pela sua legitimaçăo na sociedade (SEROA DA MOTTA, 1996; CHERMONT E SEROA DA MOTTA, 1996).

Nos casos de problemas ambientais específicos, as políticas de comando e controle são utilizadas para estipular o nivel de preservação ambiental a ser atingido. Depois de estabelecido o nivel de preservaçăo, pode-se mensurar o valor para a precificação de determinado bem em um ponto que induza os agentes econômicos a atingir o nível estipulado. É o chamado preço de indução. 
"A utilização dos instrumentos económicos complementa os instrumentos de regulação. (...) Assim, os mecanismos são estabelecidos para que o mercado funcione de forma a não ultrapassar os limites definidos por lei, ao invés de através da equivalência dos custos marginais, estabelecer o ponto ótimo destes níveis. Dessa forma, o valor monetário de cada instrumento deverá ser aquele necessário para gerar mudanças no processo produtivo ou no controle ambiental por parte dos agentes econômicos“" (SEROA DA MOTTA, 1996, pg. 88).

\subsubsection{A Incorporação dos Custos Sociais para os Resíduos Sóltdos URBanos}

A crescente geraçăo de resíduos sólidos urbanos provoca danos ambientais que não são incorporados pelas atividades de produçăo ou de consumo.

Devido à indefiniçăo dos efeitos da degradaçăo dos bens ambientais, provocados tanto pela extraçăo de recursos quanto pela disposiçăo inadequada dos resíduos sólidos gerados, o Estado pode induzir mudanças no comportamento dos indivíduos, através de políticas econômicas ambientais.

A tributaçăo pelo uso dos serviços de limpeza urbana, através da cobrança de uma taxa de limpeza urbana, tem o efeito de reduzir a quantidade de residuos gerados. Após esta etapa de reduçăo na geraçăo cabe definir políticas que estimulem a reciclagem dos resíduos sólidos urbanos ainda gerados. As atividades de reciclagem podem ser estimuladas pela concessão de créditos aos recicladores.

\subsubsection{A COBRANCA PELA GERACÃO DE RESÍDUOS SÓLIDOS URBANOS}

As políticas ambientais de gerenciamento de residuos podem atuar em dois pontos: nos efeitos dowstream, incidente após a geração de residuos; e nos efeitos upstream, com incidéncia prévia à geração, no 
caso, no próprio processo produtivo (CHERMONT e SEROA DA MOTTA, 1996).

Ainda em tramitaçăo, os Anteprojetos de Política Nacional e Estadual de Resíduos Sólidos discutem, preferencialmente, a implantação de políticas de comando e controle que atuam nos efeitos dowstream, responsabilizando os geradores de residuos por uma adequada destinação dos resíduos sólidos gerados.

Nos casos dos resíduos sólidos urbanos, para os produtores de embalagens, fica estabelecida uma co-responsabilidade na destinação final dos resíduos, entre os produtores, a administração municipal, os comerciantes e os consumidores. Além disso, para um controle das formas utilizadas para destinaçăo dos resíduos, as propostas ${ }^{9}$ de Políticas Nacional e Estadual, indicam a regulaçăo, através do estabelecimento de niveis mínimos para a reciclagem e o reaproveitamento dos materiais, ou a adoção de sistemas de depósito-retorno.

Desta forma, para os resíduos sólidos urbanos, as politicas discutidas atuam exclusivamente nos efeitos incidentes após a geração, por exemplo, a cobrança da taxa de limpeza urbana ou a cobrança pela disposiçăo final em aterros.

A partir de 1997, a CETESB passou a adotar outra forma de política de regulaçăo que atua nos efeitos dowstream da geração de resíduos sólidos urbanos. Em uma das etapas desta política de fiscalizaçăo a CETESB utiliza os TAC's - Termo de Ajustamento de Conduta, que são titulos executivos extrajudiciais, celebrados de comum acordo entre a CETESB e as administraçð̌es municipais, com anuência da Secretaria de Estado do Meio Ambiente de São Paulo, definindo prazos e atividades a serem realizados para a regulamentação ambiental das instalaçőes de destinação final dos resíduos, os lixões ou aterros, visando garantir padrões ambientais adequados para o gerenciamento dos aterros municipais (PAIVA, 2002; CETESB, 2003).

\footnotetext{
${ }^{9}$ Estas propostas podem ser consultadas on-line, no site da Assembléia Legislativa de São Paulo, disponivel em URL: http://www.al.sp.gov.br/residuos/cronog.htm.
} 
É uma política de comando e controle, executada num amplo diálogo entre as instituições envolvidas, com proposiçōes de metas progressivas e graduais a serem atingidas, para regular e garantir padrões aceitáveis para a disposição final dos resíduos.

Entretanto, para a adoção de uma política de gerenciamento dos residuos sólidos, um passo fundamental é a adoçăo de instrumentos que reduzam a geração dos resíduos na fonte, que pode ser realizada através da cobrança pelo uso dos serviços de limpeza urbana, ou seja, a taxa de limpeza urbana. Ao aumentar o preço cobrado pelos serviços, esta politica induz a uma reduçăo na demanda por estes serviços, levando a uma reduçăo na geração de resíduos na fonte. Apesar da atuação ainda estar focalizada nos efeitos dowstream, após a geraçăo, esta política tem como objetivo induzir a uma mudança no comportamento dos agentes, com a redução na fonte geradora (CHERMONT e SEROA DA MOTTA, 1996).

Os serviços de limpeza urbana são divididos, basicamente, em três grupos: os de geraçăo difusa e, portanto, indivisiveis, por exemplo, os serviços de varriçăo de ruas, originados de forma extensiva e não identificável; os de geração determinada, onde é possível identificar a fonte de geraçăo, e neste caso, o consumo dos serviços de limpeza urbana é divisivel; e os serviços complementares, que inclui os serviços com finalidades urbanísticas.

Quando a fonte de geração é determinada e, portanto, seu consumo é divisível, a grande dificuldade está em aplicar um tributo de valoraçăo a estes serviços que associe diretamente a quantidade de resíduos gerados com os valores tributados, respeitando o conceito poluidor-pagador.

Esta dificuldade decorre do alto custo administrativo necessário para a implementação desta tributação direta, devido à necessidade de informaçøes muito detalhadas sobre a quantidade gerada de resíduos por cada agente tributado e, além disso, gera a possibilidade do aparecimento 
"Normalmente, os custos decorrentes da coleta e disposição final de lixo são cobertos por receitas independentes de tais custos, ou seja, o valor que o consumidor deste tipo de serviço paga não está ligado à quantidade de lixo gerada" (SERÓA DA MOTTA e SAYAGO, 1998).

"Tal procedimento impõe uma série de restrições quanto à sua aplicabilidade, caracterizando-se como uma falha de mercado, visto que a remuneração do gerenciamento dos resíduos sólidos é, na maioria das vezes, feita de forma indireta pela utilização de orçamentos governamentais de arrecadação de impostos. Tal restrição impõe-se mais fortemente às fontes domésticas e comerciais, uma vez que a industrial oferece formas de controle mais explicitas, como por exemplo, redução de desperdícios de emissão e imposição de triagem qualitativa" (CHERMONT e SEROA DA MOTTA, 1996, p. 5).

Segundo dados da Pesquisa Nacional de Saneamento Básico PNSB, realizada pelo IBGE, que analisa a situação do gerenciamento dos residuos sólidos domiciliares, no ano de $2000,53,6 \%$ dos municípios brasileiros não cobravam pelos serviços de limpeza urbana oferecidos, retirando de outras rubricas de seus orçamentos todos os custos necessários à sua realização.

Dos municipios que cobravam pela prestação destes serviços, $45 \%$ cobravam uma taxa conjunta à taxa do Imposto Predial e Territorial Urbano - IPTU, e apenas $2,34 \%$ dos municípios cobravam uma taxa específica, conforme apresentado no Gráfico 1.

Apesar de ser a mais utilizada, a cobrança via IPTU não utiliza o conceito poluidor-pagador. Ao associar esta cobrança ao IPTU, a taxa é fixada sobre cálculos que dizem respeito ao imóvel, como localização e tamanho da área, uma taxa fixa e pré-determinada que não corresponde ao montante de resíduos gerados. Assim o custo para gerar pouco ou muito resíduo é o mesmo, e não provoca a indução de mudança de comportamento dos agentes. O que leva à geração de uma quantidade inadequada de residuos para a disposição final. 
comportamento dos agentes. O que leva à geração de uma quantidade inadequada de residuos para a disposição final.

\section{GRÁFICO 1 - Percentual de Municípios, por Existência de cobrança dos serviços de limpeza pública, Brasil, 2000}

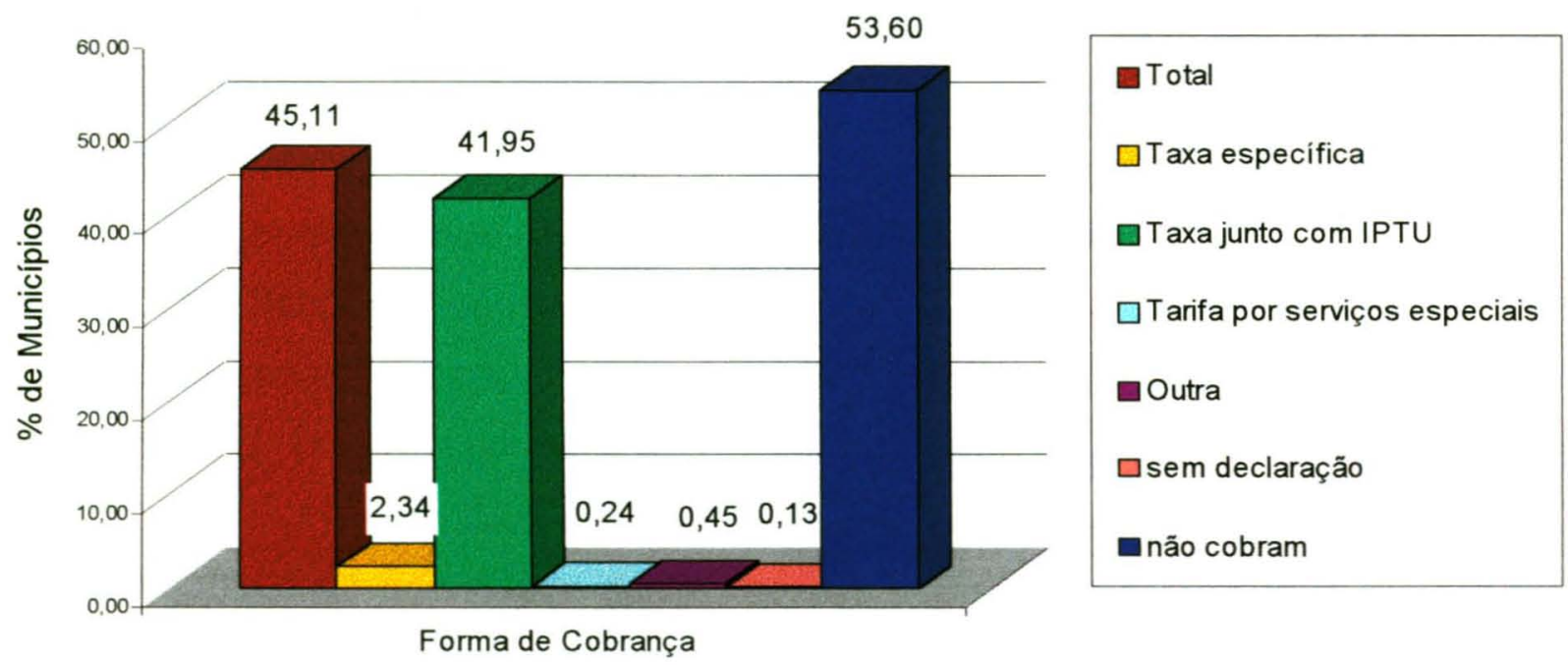

Fonte: IBGE, 2001 - Tabela 100. Elaborado pela autora.

Entre a dificuldade de tributação direta pela geração de resíduos e as formas utilizadas pelas prefeituras, que pouco influenciam a demanda pelos serviços de limpeza urbana, pode-se utilizar formas alternativas para estipular o valor da tributação, que de alguma maneira associem a cobrança à geração de resíduos, propiciando a mudança no comportamento dos agentes.

Assim, outras políticas, que não seguem à risca o sistema de valores via mercado, podem ser adotadas. Estas políticas procuram estipular um valor balizador para os custos ambientais, com a presença do Estado, na definição do nivel ótimo de poluição a ser atingido.

O preço balizador dos serviços de limpeza urbana deve incorporar tanto os custos privados, como a coleta, o transporte e a administração dos aterros, quanto os custos ambientais evitados pelo tratamento dos resíduos. Assim, utiliza-se uma mescla de políticas de comando e 
controle com instrumentos econômicos. O valor do tributo, definido pelo estado, deve estar num nivel que induza a mudanças no comportamento dos agentes, reduzindo a geraçăo dos resíduos até que se atinja um ponto adequado de poluição admitida (CHERMONT e SEROA DA MOTTA, 1996).

Entre as alternativas adotadas para estipular este valor balizador para a cobrança pelo uso dos serviços de limpeza urbana, já realizadas em alguns municipios brasileiros, é feita a cobrança utilizando como parâmetro a quantidade de água ou energia consumida em uma residéncia. Conforme ocorra um aumento no consumo residencial de água ou de energia pressupōe-se um aumento proporcional também na quantidade de resíduos gerados, naquela determinada residéncia.

No município de São Paulo, a forma utilizada é a auto-declaraçăo do contribuinte da quantidade de lixo gerada semanalmente, com taxas divididas em escalas de geração.

Entre as medidas citadas nas atuais propostas de Políticas Nacional e Estadual de Resíduos Sólidos, ainda em discussão, para a mensuraçăo desta cobrança săo listadas: a caracterizaçăo das atividades realizadas em determinada regiăo; a correlaçăo com o consumo de outros serviços públicos; a quantidade e a freqüência dos serviços prestados; a avaliaçăo histórica e estatística em cada região homogénea; e, no caso da política estadual, é incorporada a autodeclaraçăo pelo usuário.

Para otimizar os resultados obtidos por esta tributaçăo, através do vetor balizador, deve-se considerar o caráter progressivo do tributo, diferenciando os tipos de geradores pela quantidade e qualidade dos resíduos; realizar a conscientizaçăo dos agentes sobre as vantagens obtidas com o sistema, para que estejam dispostos a cooperar; a utilizaçăo de um sistema contábil e de administração desta taxa deve ser compativel com outros sistemas já utilizados; e o instrumento econômico deve ser conciliado com mecanismos de comando e controle (SEROA DA MOTTA, 1996). 
I na utilizaçăo desta politica, que inclua os custos sociais mpeza urbana prestados, está em associar a geração de receitas para o Estado, pela utilização de instrumentos econômicos, de mais simples aplicação do que as políticas de comando e controle que procuram garantir o conceito de poluidor/pagador e com isto induzir uma mudança de comportamento nos agentes envolvidos.

\subsubsection{INCENTIVO ECONÔMICO ÀS ATIVIDADES DE RECICLAGEM}

Após adotar este vetor balizador que induza a um nível adequado na geração de resíduos na fonte, o segundo passo consiste em dar uma destinaçăo adequada ao montante de resíduos gerados (CHERMONT e SEROA DA MOTTA, 1996).

De acordo com os dados da Pesquisa Nacional de Saneamento Básico - PNSB, para a disposiçăo final dos resíduos sólidos domiciliares, no Brasil, para o ano de 2000 , as opções mais utilizadas para a destinaçăo das toneladas coletadas diariamente seguem a seguinte ordem: aterro controlado, com $37 \%$ das toneladas coletadas diariamente; aterro sanitário, $36 \%$; lixões, $21 \%$; estação de compostagem, $3 \%$; estação de triagem, $1 \%$ e outras, com $1,8 \%$ (IBGE, 2001).

A disposição no solo, em aterros ou lixões, é a opção mais utilizada para a destinação final dos resíduos sólidos urbanos no país, sendo que $58 \%$ das toneladas diárias geradas são destinadas a lixões ou aterros controlados, formas inadequadas no controle à degradação ambiental.

Mesmo quando dispostos em aterros sanitários, esta forma de destinação final de resíduos ainda implica em efeitos danosos ao meio ambiente, com a geração de chorume e de gases poluentes que requerem um rigoroso controle, elevando o custo financeiro desta alternativa, além do problema da falta de áreas disponíveis para a instalaçăo de novos aterros, especialmente nas grandes cidades.

Desta forma, após a redução na geraçăo e a reutilização dos materiais, a alternativa mais adequada para os resíduos sólidos, especialmente para os resíduos inorgânicos, é a reciclagem. A 
importância desta atividade está em aumentar a substituição de matériasprimas por materiais recuperados o que diminui a demanda por recursos naturais, evitando tanto os custos sociais causados pela poluição quanto os custos da extração ou esgotamento dos recursos ambientais, além de reduzir a necessidade de expansão de aterros, devido ao aumento da vida útil.

Como foi visto, grande parte das atividades de reciclagem estão localizadas no setor informal da economia. No mercado de reciclagem, o preço do material, apesar de estar em expansão, reflete apenas o valor privado do reaproveitamento. Assim, o que determina 0 nivel de reciclagem no processo produtivo é a relaçăo entre o custo de utilizar a matéria-prima virgem e a matéria reaproveitada. Quanto maior for o custo de se extrair matéria-prima virgem maior será o incentivo à reciclagem de materiais.

O valor econômico da reciclagem inclui apenas os benefícios privados do reaproveitamento, como os gastos economizados de utilização de matéria-prima e outros insumos. Devido à grande concentração e à característica oligopsônica ${ }^{10}$ deste mercado, não é imputado os reais custos de oportunidade no reaproveitamento dos materiais, representados pelos custos sociais evitados.

É o que acontece, por exemplo, no preço de mercado do vidro, situado abaixo do benefício social deste reaproveitamento. Já no caso do alumínio, os valores econômicos são suficientemente altos para induzir a um bom nível de reciclagem (SEROA DA MOTTA e SAYAGO 1998).

Pelo estudo realizado por Calderoni (1999), a reciclagem envolve, além dos custos privados, os custos sociais e ambientais evitados, como economia de energia, de água, de recursos naturais e dos gastos evitados pela maximização do espaço utilizado e da vida útil dos aterros.

Os custos sociais evitados pela reciclagem são sentidos por toda a sociedade, enquanto que os custos privados incidem ou apenas sobre os agentes privados que realizam a reciclagem, pelos custos de transporte e 
beneficiamento dos materiais ou sobre os municípios, pelos programas de coleta seletiva de lixo (SEROA DA MOTTA e SAYAGO, 1998).

Desta forma, nem sempre o preço de mercado equivale ao real benefício social do reaproveitamento dos materiais.

Uma opção de política governamental para aumentar o nivel de reciclagem também para os materiais de baixo valor no mercado é adotar o incentivo à reciclagem, que incorpore os custos sociais no reaproveitamento dos materiais. $O$ incentivo econômico, neste caso, funciona como um subsídio para incentivar a atividade dos recicladores, para todos os tipos de materiais. $E$ um instrumento econômico que atua na forma de prêmios, através do crédito subsidiado (CHERMONT e SEROA DA MOTTA, 1996).

Esta política de gerenciamento dos resíduos sólidos urbanos com incentivo à reciclagem pode ser combinada tanto com uma política de cobrança sobre o uso dos serviços de limpeza urbana (CHERMONT e SEROA DA MOTTA, 1996), quanto com uma politica de tributaçăo sobre os produtos, incidente nos efeitos upstream que atuam no processo produtivo (SEROA DA MOTTA e SAYAGO, 1998).

Segundo Chermont e Serôa da Motta (1996), quando combinada com a política de cobrança pelo uso dos serviços, por exemplo, a taxa de limpeza urbana, o critério para mensuração do subsídio à reciclagem deve estar atrelado aos custos evitados pela disposição final em aterros.

"Créditos para a reciclagem são utilizados na Inglaterra e nos EUA. $\mathrm{Na}$ Inglaterra, o governo paga aos agentes diretamente envolvidos com a reciclagem dos resíduos sólidos urbanos e que, portanto, geram economias em termos de custos evitados de disposiçăo final e além disso, garante demanda estatal aos produtos reciclados. Nos EUA, existe um sistema integrado de concessão de créditos ou deduçōes de impostos para investimentos em equipamentos de reciclagem, isenções de impostos sobre vendas na compra de tais equipamentos e, ainda, uma

\footnotetext{
${ }^{10} \mathrm{O}$ mercado oligopsônico possui poucos compradores que conseguem estipular, com facilidade, 0 preço pago pelos produtos. É o contrário do oligopólio, com poucos vendedores.
} 
variedade de empréstimos ou prêmios relacionados com a atividade recicladora" (CHERMONT e SEROA DA MOTTA, 1996, p. 15).

Entretanto, quando se opta pela política de tributação sobre produtos deve-se evitar a cobrança pelo uso dos serviços, pois isto provocaria uma dupla-triutação.

Serôa da Motta e Sayago (1998) sugerem a adoção de uma política upstream, e visando uma açăo federal e de impacto no setor industrial, a concessão de créditos aos recicladores, via Imposto sobre Produtos Industrializados - IPI.

Como os materiais recicláveis năo são tributados pelo IPI, com exceçăo do plástico, o crédito presumido equivaleria à carga de IPI tributada sobre o material que originou a embalagem, ou seja, na carga de IPI tributada anteriormente sobre o material, e que ao ser retornado para o processo produtivo geraria um crédito em favor dos recicladores ${ }^{11}$.

Além do crédito presumido, Seróa da Motta e Sayado (1998) ainda sugerem a utilizaçăo de mais dois possiveis instrumentos, a criação de um tributo específico para as embalagens, de acordo com cada especificidade; ou a utilização do sistema depósito-retorno, projeto de lei $n^{\circ}$. 3750/97 do deputado federal Fernando Gabeira, com a extensão desta proposta a todas as embalagens e com um ajuste na alíquota a ser tributada.

Neste caso, o uso combinado com uma politica de tributação sobre os produtos, o subsídio à reciclagem seria feito através de uma transferência de renda dos usuários de embalagens para os recicladores e a sociedade como um todo.

Desta forma, adota-se uma postura de encarar a reciclagem não apenas como uma atividade privada, mas como uma política de gerenciamento de resíduos e de otimizaçăo nos níveis de poluição

\footnotetext{
${ }^{11} \mathrm{O}$ crédito presumido para recicladores foi discutido pela Comissão de Politica Nacional de Resíduos Sólidos, pelo Projeto Lei no. 2.201/99 do deputado José Carlos Vieira. Em votação, o projeto foi aprovado por sua constitucionalidade e boa técnica, entretanto foi indicada a inadequação orçamentária e financeira da proposição da lei pelo fato de não obedecer aos critérios da LDO de demonstrar o efeito da redução ou subsídio tributário nas receitas, que não pode afetar as metas fiscais.
} 
gerados. $O$ crédito de reciclagem advém da tributação que visa reduzir a quantidade de lixo gerado, através de uma política ambiental que interfere no comportamento dos indivíduos para a redução na geração de resíduos.

\subsubsection{A inclusão das cooperativas de catadores pelo incentivo à reciclagem}

A inclusão das cooperativas de catadores nos programas municipais de coleta seletiva é discutida pelas propostas de Políticas Nacional e Estadual de Resíduos Sólidos.

O Anteprojeto de Política Nacional de Resíduos Sólidos propõe a criaçăo de um Fundo Nacional de Resíduos Sólidos, com fonte de recursos provenientes de: dotaçס̄es consignadas na lei orçamentária anual; doaçס̃es realizadas; recursos derivados de acordos entre entes do setor público, receitas proveniente de multas pelo não cumprimento da lei.

Os municipios ficam livres para decidir a conveniência de criar um Fundo Municipal de Resíduos Sólidos, com receitas provenientes do recurso orçamentário dos municípios; da arrecadaçăo dos preços públicos de limpeza urbana.

O repasse de recursos do Fundo Nacional de Resíduos é proposto, preferencialmente, aos municípios que incluam cooperativas, associações ou organizações sociais de trabalhadores que se dediquem à coleta de resíduos.

Entretanto, a restrição orçamentária dos órgăos públicos cria a necessidade de políticas ambientais que incluam os custos sociais gerados e năo incorporados pelas atividades de produção e de consumo.

A adoção de politicas que induzam a redução na geração dos resíduos sólidos urbanos através da cobrança pela taxa de limpeza urbana poderia gerar maiores disponibilidades de recursos financeiros que seriam transferidos para estimular as atividades dos recicladores, através do crédito à reciclagem. 
Cabe ressaltar que os dois anteprojetos de lei, descritos acima, discutem a concessão de incentivos fiscais para as atividades de reciclagem.

O anteprojeto de Política Estadual de Resíduos Sólidos lista entre seus objetivos (art. $3^{\circ}$.) a promoçăo e ressocializaçăo de catadores, inserindo-os na execuçăo de projetos de coleta seletiva, incentivando o desenvolvimento de cooperativas e associaçőes na coleta e separaçăo de materiais recicláveis.

O subsídio à reciclagem poderia ser utilizado como fomento de políticas públicas para a coleta seletiva solidária. Como vimos, tanto os catadores quanto os sucateiros trabalham na informalidade. Pesquisas poderiam ser financiadas para capacitaçăo tecnológica e gerencial das atividades destes recicladores, além de constituir numa fonte financeira para a implantaçăo de coleta seletiva, melhorando com isto a qualidade e a quantidade do material a ser recuperado.

Esta intervençăo estatal, além de provocar uma melhor utilização dos recursos naturais pela reduçăo na fonte geradora de resíduos e pela adoçăo de formas de tratamento e disposiçăo final mais adequadas, ainda pode gerar recursos para estruturar a frágil inserção dos catadores no mercado de reciclagem. 


\section{Estudo de Caso}

\subsection{CoOperativas de Catadores de materiais recicláveis Na Região Metropolttana de São Paulo}

No Brasil, 237 municípios realizam programas de coleta seletiva de lixo. Estima-se que, no país, cerca de 500 mil pessoas trabalhem como catadores de materiais recicláveis. Em muitos casos, estes catadores estão inseridos em programas municipais de coleta seletiva solidária. Estes programas, em geral, são mantidos através de uma responsabilidade compartilhada entre o poder público, os catadores e suas cooperativas e a sociedade civil (CEMPRE, 2002).

Foi realizado um estudo de caso em três cooperativas de catadores de materiais recicláveis, situadas na Região Metropolitana de São Paulo. Este estudo procurou identificar as diferentes estruturas nestas cooperativas de catadores, assim como, a relação existente entre estes catadores com o poder público municipal, com o mercado de reciclagem $e$ com a sociedade civil.

Foram selecionadas as seguintes cooperativas: a Cooperyara, situada no município de Barueri, a Associação Raio de Luz, no município de São Bernardo do Campo e o Projeto Vira Lata, localizado no bairro de Pinheiros, na cidade de São Paulo.

Todas estas cooperativas estão incluídas nos programas municipais de coleta seletiva de lixo. Entretanto, a Cooperyara, de Barueri, e a Associação Raio de Luz, de São Bernardo do Campo, foram formadas por iniciativa das respectivas prefeituras. Já, o Projeto Vira Lata, em São Paulo, foi organizado pela Associação de Moradores do Bairro Jardim Boa Vista, em 1998. Somente em outubro de 2003, este Projeto começou a participar do programa de inclusão dos catadores, implantado pela prefeitura de São Paulo, a partir de 2002. 


\subsubsection{Cooperyara - Barueri}

As atividades da Cooperyara - Cooperativa de Trabalho dos Profissionais de Reciclagem de Lixo do Município de Barueri e Região tiveram início em abril de 2002, por iniciativa da Secretaria Municipal de Recursos Naturais e Meio Ambiente, através de uma política pública municipal para retirar os catadores do antigo lixão.

Em 1999, este lixão foi avaliado pela CETESB e recebeu a nota de 1,5 pelo índice de Qualidade em Aterros - IQR ${ }^{12}$. Apesar de ter ocorrido melhorias, em 2003, este indice estava em 3,6, o que evidenciava, ainda, condiçöes inadequadas para o destino final de resíduos sólidos urbanos em Barueri. Pela avaliaçăo da CETESB, para que as condiçōes sejam consideradas como controladas este indice deve estar entre 6,0 e 8,0. Para serem consideradas adequadas deve estar acima de 8,0.

Atualmente está em andamento, no município de Barueri, o TAC Termo de Ajuste de Conduta, firmado entre a CETESB e a prefeitura com o intuito de promover melhorias na operação do aterro (CETESB, 2003).

Com isto, a denominação do lixão foi modificada para aterro emergencial, pois as camadas inferiores ainda continuam poluindo o meio ambiente, mas $O$ aterro recebeu uma camada impermeabilizante e para as camadas superiores já é realizada a drenagem do chorume. A administração do aterro é feita pela prefeitura, através da Secretaria de Serviços Municipais.

Em 2000, foi dado o início da retirada das crianças e das mulheres que trabalhavam no lixão, que não era nem cercado. Nesta época a Secretaria Municipal do Meio Ambiente, que foi criada apenas em janeiro de 2001, ainda era um departamento ligado à Secretaria Municipal de Habitação.

\footnotetext{
${ }^{12} \mathrm{IQR}$ - Índice de Qualidade em Aterros, indice criado pela CETESB, que reúne informaçðes através de inspeçōes nos locais de destinação final dos resíduos. Estas informaçð̃es são coletadas por um questionário padronizados, que visa identificar as características locacionais, estruturais e operacionais de cada instalação.
} 
Entretanto, a retirada dos catadores apresentava um problema, criar alternativas para a geração de renda destas pessoas. Foi para garantir o trabalho a estas pessoas que foi fundada a Cooperyara. Esta política obteve éxito e, atualmente, não existem mais catadores trabalhando no antigo lixão.

As instalações da cooperativa localizam-se no terreno do aterro, onde foi construído um galpão de $300 \mathrm{~m}^{2}$, com uma esteira de triagem de 15 metros, duas prensas (uma vertical e uma hidráulica horizontal), uma Moega de recebimento dos materiais e carrinhos transportadores. Todos estes itens são utilizados pela Cooperyara por um contrato de comodato (concessăo de uso) com a prefeitura.

A Lei Municipal $n^{\circ}$. 1.320, de 2 de Setembro de 2002, instituiu o Programa de Coleta Seletiva de Materiais Recicláveis, de caráter sócioambiental que tem como objetivos: reduzir a quantidade gerada de resíduos, estimular a educaçăo ambiental e "erradicar o trabalho no lixo e com o lixo nas dependências da área de disposição dos resíduos sólidos de responsabilidade da Prefeitura.

Esta lei autoriza a Prefeitura a realizar parcerias e/ou convênios com organizações da sociedade civil, sem fins lucrativos, com o intuito de realizar a triagem dos materiais recicláveis, sendo priorizados os trabalhos que tenham como finalidade a preservaçăo do meio ambiente e a organização social, bem como a valorização profissional e humana de pessoas que trabalhem no lixo e com o lixo.

A contratação das organizaçōes sociais sem fins lucrativos é feita nos termos da Lei Federal $n^{\circ} 9.637$, de 15 de maio de 1998. Esta lei define estas organizações sociais, no artigo $1^{\circ}$, como pessoas jurídicas de direito privado, cujas atividades sejam dirigidas ao ensino, à pesquisa científica, ao desenvolvimento tecnológico, à proteção e preservação do meio ambiente, à cultura e à saúde. A finalidade não-lucrativa da organização advém da obrigatoriedade de investimento de seus excedentes financeiros no desenvolvimento das próprias atividades (BRASIL, 1998). 
Apesar de nos termos desta lei federal (LEI $n^{\circ}$. 9.367/98) os contratos com as organizações sociais estarem referidos como contratos de gestão, na prática, em Barueri, a contratação pela Cooperyara foi realizada via convênio administrativo.

O convênio administrativo é um acordo firmado entre entidades públicas de qualquer espécie, ou entre essas e organizaçōes particulares para execução de interesses comuns entre os participes. Desta forma, não representa um contrato já que os interesses não se contrapõem (PAIVA, 2002).

Esta modificação é justificada, segundo informações fornecidas pela Secretaria do Municipal Meio Ambiente, pelo fato de que na época da realização deste contrato o estatuto da Cooperyara ainda não havia sido regularizado, impedindo a contratação desta organização por contrato de gestão.

Ainda segundo a Lei Federal $n^{\circ}$ 9.637, as entidades qualificadas como organizaçōes sociais são declaradas como entidades de interesse social e utilidade pública, para todos os efeitos legais. Assim, às organizaçōes sociais podem ser destinados recursos orçamentários e bens públicos necessários ao cumprimento do contrato estabelecido. Para estes bens, que serão destinados às organizações sociais, é dispensada licitação, mediante permissão de uso, de acordo com uma cláusula expressa no contrato (BRASIL, 1998).

A partir destas determinações legais, todo o material reciclável coletado pela prefeitura pode ser doado à cooperativa para a triagem e a comercialização sem que haja licitação, mas deve ser cumprida a exigência de que a entidade seja uma organização social sem fins lucrativos para que se atinja os interesses sociais e de utilidade pública, que é a valorização do trabalho destas pessoas.

Para isto, é necessária a discriminação das atividades realizadas pela cooperativa, em estatuto ${ }^{13}$. Na Cooperyara, apesar das atividades

\footnotetext{
${ }^{13}$ As cooperativas são por definição uma sociedade de pessoas que reciprocamente se obrigam a contribuir com bens ou serviços para o exercício de uma atividade econômica, de proveito comum, sem objetivo de lucro. (Lei Federal $\mathbf{n}^{\circ}$. 5.764/71).
} 
terem se iniciado em abril de 2002, o estatuto só foi aprovado na Junta Comercial, em novembro de 2002. Este estatuto foi em grande parte elaborado e redigido pelos próprios associados da Cooperyara, com a assessoria de funcionários da Prefeitura, num rico processo de aprendizagem.

O estatuto da Cooperyara, na especificação das atividades da cooperativa, tem uma abordagem ampla, incluindo as atividades de coleta, separação, processamento, armazenamento e comercialização dos materiais recicláveis, possibilitando uma estruturação completa na atividade de reciclagem desenvolvida pelos seus associados.

Além disto, permite a congregação da cooperativa com toda a rede de recicladores, incluindo os coletores, selecionadores de materiais recicláveis, transportadores, por veículos motorizados ou carrinhos, técnicos do meio ambiente, assim como, profissionais correlatos a estas profissões. Esta congregação tem o objetivo de propiciar a defesa econômica e social, além da criaçăo de condiçōes para o exercício destas atividades, para com isso aprimorar a prestação de serviços de seus associados.

Apesar de prevista pelo estatuto, atualmente, a coleta dos materiais recicláveis não é realizada pela cooperativa. A prefeitura faz a concessão na prestaçăo destes serviços à empresa Intranscol, que promove a coleta seletiva do lixo em $100 \%$ da área urbana do município de Barueri. Esta coleta é feita pelo sistema porta a porta e é realizada duas vezes por semana. Apesar de ser estendida a todo o município, segundo informações da Secretaria Municipal do Meio Ambiente, é baixa a adesão a este serviço, algo em torno de $20 \%$ a $30 \%$ da população, para 0 ano de 2004.

A renda obtida pela Cooperyara provém unicamente da comercialização destes materiais no mercado informal da reciclagem.

Na sua relação com os compradores, a Cooperyara não realiza nenhum tipo de beneficiamento dos materiais coletados. Suas atividades ficam reduzidas à separaçăo, ao enfardamento, atividades classificadas 
como pré-beneficiamento, e à comercialização dos materiais triados. Não realiza a venda direta à indústria recicladora, ficando dependente do intermédio de sucateiros e outros comerciantes, para todos os tipos de materiais recuperados por seus associados.

Quanto à participação da sociedade civil e de Organizações NãoGovernamentais, a Fundação AlphaVille ${ }^{14}$ colabora para a promoção da coleta seletiva de lixo na cidade de Barueri, através da conscientização ambiental e, além disso, fez a doação do computador utilizado atualmente na Cooperyara.

Cabe ressaltar outras importantes atividades realizadas pela Fundação Alphaville que incentivou a formação de uma cooperativa de artesanato, que utiliza materiais recicláveis, para as mulheres que trabalhavam no antigo lixão e promoveu atividades educativas com os filhos dos catadores para revelar a importância ambiental do trabalho realizado pelos seus pais.

Em relação às normas cooperativistas, foi observada a autogestão e a participação democrática dos associados nas tomadas de decisões. Neste processo a cooperativa conta com o apoio dos técnicos da prefeitura e de voluntários da Fundação Alphaville, sempre que preciso.

Entretanto, quanto à aplicação obrigatória de recursos para a manutençăo da cooperativa, a Cooperyara já recolheu, mas atualmente estão inativos os fundos de aplicação de recursos, apesar destes fundos estarem previstos no estatuto e serem obrigatórios por lei. Estes fundos são: o Fundo de Reserva, constituido por $10 \%$ das sobras liquidas das atividades, e o Fundo de Assistência Técnica e Social - FATES, constituído por pelo menos $5 \%$ destas sobras.

Apesar disto, todos os associados da Cooperyara recolhem a contribuição para o Instituto Nacional do Seguro Social - INSS.

\footnotetext{
${ }^{14}$ A Fundação AlphaVille foi criada pela AlphaVille Urbanismo S.A. e é uma entidade que desenvolve diversos programas valorizando o meio ambiente, a geração de renda e trabalho, o urbanismo e os patrimônios históricos.
} 


\subsubsection{Associação Raio de Luz - São Bernardo do Campo}

A Associação Raio de Luz foi fundada em março de 2000, por iniciativa da Prefeitura de São Bernardo do Campo, mediante um trabalho integrado e intersetorial entre diferentes secretarias.

O projeto de inclusão dos catadores na coleta seletiva de lixo teve início com o programa Cidade Linda. Devido a este programa o município recebeu o apoio da UNICEF, em 1998, para a erradicação do trabalho infantil na cidade.

Em 2000, com o fechamento do lixão Alvarenga e devido ao apoio da UNICEF, a prefeitura estabeleceu parcerias com o Instituto Pólis, o SEBRAE e a USP, pela Faculdade Politécnica, para a criação de alternativas de geração de renda para os catadores expulsos do antigo lixão.

Durante este processo, foram realizados cursos sobre a caracterização dos materiais recicláveis, sobre os métodos de triagem, sobre o sistema cooperativista e foram desenvolvidas atividades educativas, entre os catadores, para a conscientização do pertencimento sobre o projeto e sobre o próprio trabalho, num resgate da auto-estima.

Atualmente, o programa municipal de coleta seletiva de lixo inclui duas associaçóes de catadores de materiais recicláveis. Estas associações são: a Raio de Luz, inicialmente composta apenas por antigos catadores de ruas; e a Refazendo, inicialmente composta por antigos catadores de lixões.

Esta divisão entre os catadores foi realizada, pela prefeitura, devido a uma diferenciação observada no comportamento destes dois grupos de catadores causada pela trajetória de vida de cada grupo, baseadas em diferentes experiências.

Ao todo, 80 catadores convivem em dois espaços denominados de Centro de Ecologia e Cidadania. Um deles se localiza no Bairro Assunção, sede da Associação Refazendo e o outro se localiza no Bairro 
Rudge Ramos, sede da Associação Raio de Luz, que foi incluída nesta pesquisa.

Estes Centros de Ecologia e Cidadania foram construidos especialmente para este projeto da prefeitura, que visa promover e valorizar o trabalho dos catadores. A construção destes centros foi planejada para estruturar o espaço de trabalho e de convivência dos catadores.

Além disso, com o objetivo de promover atividades educativas, estes centros possuem lousa e cadeiras instaladas na copa, que pode ser transformada em sala de aula. Atualmente, na Associação Refazendo, os catadores recebem aulas de alfabetização. Na Associação Raio de Luz estas aulas não são ministradas porque grande parte dos seus integrantes já é alfabetizada.

Os materiais utilizados por estas associações de catadores são doados pela prefeitura que realiza a coleta seletiva de lixo através dos Postos de Entrega Voluntária - PEV's, denominados de Ecopontos, num número de 200 unidades espalhadas pela cidade.

Segundo informaçōes dadas pelos técnicos da Secretaria Municipal do Meio Ambiente, a prefeitura optou por realizar a coleta seletiva através do sistema de PEV's porque pelo sistema porta a porta a quantidade coletada é maior, mas a população não segrega adequadamente os resíduos em casa. Já, no sistema de coleta por PEV's, apesar da quantidade ser menor garante-se a qualidade do material coletado.

Entretanto, segundo o minucioso estudo realizado por Bringhenti (2004) sobre os aspectos operacionais da coleta seletiva de lixo, o sistema de coleta por PEV's apresenta um custo elevado em relação à quantidade de materiais coletados, devido ao custo dos equipamentos utilizados e a manutençăo periódica que tem que ser feita nestes equipamentos.

Em Barueri, segundo informaçōes da Secretaria Municipal do Meio Ambiente, para o ano de 2004 , o municipio coletava $8 \%$ do material que poderia ser reciclado. A prefeitura fez a concessão da prestação dos 
serviços de coleta de lixo à empresa Vega Ambiental que coleta os materiais recicláveis nos Ecopontos e os transporta até os Centros de Ecologia e Cidadania.

Quanto ao estatuto da Associação Raio de Luz, incluída nesta pesquisa, sua aprovação ocorreu no ano de 2001, com prazo indeterminado de duração.

Entre seus objetivos estão listados: a defesa econômico-social dos associados, por meio de ajuda mútua para a promoção das condições de trabalho na separação e venda dos recicláveis; o incentivo à organização e à sistematização de pessoas que vivem da catação; o desenvolvimento da solidariedade entre os catadores; a busca da dignidade para a função do catador junto à comunidade; a qualificação nos processos de seleção, classificação e venda para viabilizar a sobrevivência do grupo e de cada catador; e a integração do grupo para que os catadores caminhem para o cooperativismo formal.

Para que estes objetivos sejam alcançados, o estatuto especifica as atividades a serem realizadas pela Associação. Estas atividades são: adquirir, construir ou alugar instalações; promover a coleta, o transporte, o beneficiamento, o armazenamento, a separação e a comercialização dos recicláveis; e contratar serviços de assistência médica, dentária, recreativa, podendo para isso manter convênios ou contratos com entidades públicas e privadas.

As associações de catadores têm permissão de uso para utilizar o espaço especialmente construido para este objetivo, os Centros de Ecologia e Cidadania, os quais contam com um galpão que possui prensas, enfardadeiras e trituradoras, uma sala para escritório, dois banheiros, copa e cozinha.

Entretanto, a prefeitura não formalizou nenhum contrato jurídico para este vínculo com as associaçōes de catadores. Segundo informações fornecidas por técnicos da Secretaria Municipal do Meio Ambiente, estas organizações foram criadas como associações para definir o período de incubação e capacitação das atividades dos 
catadores. A transformação em cooperativas será realizada quando o grupo de associados estiver amadurecido com o trabalho e por isso não foi definido um prazo para o fim das atividades de incubação.

Quanto à inserção da Associação Raio de Luz no mercado de reciclagem, a comercialização dos materiais triados é feita exclusivamente com sucateiros e intermediários da região e a associação realiza apenas as atividades de pré-beneficiamento (triagem e enfardamento) dos materiais coletados. Apesar disto, por estar situada numa região industrial, a associação recebe a doação de algumas empresas e comércios da região.

Quanto ao apoio da sociedade civil, não foi identificada a participação de nenhuma organização que colabore regularmente para as atividades da associação. $O$ apoio recebido é realizado unicamente, por intermédio ou diretamente, pelos funcionários da prefeitura.

Em relação às normas cooperativistas, o intenso apoio da prefeitura não prejudica a garantia da autogestão e da participação democrática dos associados nas tomadas de decisões. A prefeitura atua apenas quando é chamada para dar orientaçōes.

Quanto à arrecadação dos fundos de aplicação dos recursos, a Associação Raio de Luz recolhe, todo mês, o percentual exigido para a manutenção do Fundo de Reserva, de $10 \%$ das sobras líquidas para a manutenção das atividades. Entretanto, não recolhe recursos para a constituição do FATES, estabelecido em no mínimo 5\% destas sobras.

\subsubsection{Projeto Vira Lata - São Paulo}

O projeto Vira Lata foi criado em 1998, por iniciativa da Organização de Moradores de Bairro do Jardim Boa Vista, situado na zona oeste do município de São Paulo.

Esta organização de moradores de bairro atua na região desde 1977 e teve participação ativa na construção de creches, pavimentação das ruas, canalização de rede de esgoto e de água, de energia elétrica, 
regularização de loteamentos em favelas e escolas da região. Sua composição é formada por representantes de igrejas, por representantes de conselhos escolares, por profissionais autônomos das áreas da saúde e educação, por síndicos e moradores de condomínios, além de representantes de associações de favelas.

Preocupada com a situação de desemprego entre os moradores da região, esta organização de moradores decidiu organizar o Projeto Vira Lata, que através da educação ambiental, coleta seletiva de lixo e da recuperação e comercialização dos materiais recicláveis, geraria condiçōes de trabalho e renda, como alternativa ao desemprego.

Para isso, inicialmente, foi realizado um cadastro das pessoas desempregadas da região e, em 1998, o Projeto contava apenas com 4 pessoas que realizavam a coleta seletiva porta a porta e divulgavam o objetivo desta iniciativa nas residências, comércios e escolas da região. Desta forma, os catadores cumpriam também o papel de educadores ambientais, promovendo a coleta seletiva de lixo na região. Durante este periodo, a coleta era realizada em parte por carrinhos e em parte com a ajuda de uma perua, que era de propriedade de um dos catadores envolvido no Projeto.

Com o passar do tempo o Projeto Vira Lata foi crescendo e para formalizar 0 apoio dado pela associaçăo de moradores foi criado um estatuto para a Associação Vira Lata. A cooperativa de catadores, ou seja, o Projeto Vira Lata, é uma das iniciativas desta Associação. Neste estatuto está especificada a formação de uma diretoria composta por um Diretor-Presidente, um Diretor-Financeiro e um Diretor de Eventos. As três pessoas que ocupam estes cargos são pessoas que participam ativamente das atividades realizadas pela Associação de Moradores do Bairro Jardim Boa Vista, e não recebem remuneração pelo apoio dado ao Projeto Vira Lata.

Cabe ressaltar, que ao contrário da Cooperyara, que já é uma cooperativa, e da Associação Raio de Luz, que está em fase de 
incubação para se tornar uma cooperativa, os catadores do Projeto Vira Lata ainda não estão formalizados como uma cooperativa.

Entretanto, o apoio dado pela diretoria é bastante dinâmico e têm sido fundamental para consolidar o trabalho dos catadores envolvidos no Projeto, pelo sistema cooperativista.

Graças a este apoio, as atividades de educação ambiental são realizadas até hoje, nas residências, comércios e condomínios e também por palestras em escolas da região.

Além disso, durante um período de dois anos, foi editado o Boletim Vira Lata, com a divulgação da contabilidade do Projeto Vira Lata para todos os seus colaboradores. Este Boletim incluía, ainda, textos sobre diversos assuntos, como meio ambiente, reciclagem, cooperativismo, e mercado de trabalho. Com a extinção do Boletim, a prestação de contas para a sociedade continua a ser feita através da internet, via e-mail.

A contabilidade dos dados é feita pelos próprios catadores, entretanto devido à falta de computador e à falta de acesso à internet, a divulgação destes dados é feita pelo presidente da diretoria, que conta também com a ajuda de outros voluntários.

Devido a este processo de transparência nas informações e à abordagem direta com a sociedade civil o Projeto Vira Lata conquistou, cada vez mais, o apoio de toda a comunidade local.

Atualmente, a atividade de coleta não é mais realizada por carrinhos. Agora, a coleta é feita no sistema porta a porta por 2 caminhões e 1 veículo Topic, nos bairros do Butantã, Jaguaré, Raposo Tavares, Rio Pequeno e Vila Sônia.

O Projeto Vira Lata conta com o apoio, através da doação de materiais, de condomínios residenciais e algumas empresas localizadas nas proximidades da Rodovia Raposo Tavares, como supermercados e shopping centers, além das doações feitas pela Editora Globo e pela Associação Comercial de São Paulo. Também são realizadas parcerias com 15 escolas públicas, onde se desenvolve a conscientização a respeito da questão do lixo e da reciclagem. 
Quanto ao apoio recebido pelo poder público municipal, a atual sede do Projeto Vira Lata está situada no antigo incinerador de Pinheiros, espaço utilizado por concessão de uso pela prefeitura. A mudança da sede para este espaço aconteceu no final de 2002.

Além disso, a partir outubro de 2003, o Projeto Vira Lata começou a participar do programa realizado pela prefeitura de São Paulo para a inclusão das cooperativas de catadores na coleta seletiva de lixo.

Este programa foi realizado devido ao reconhecimento da importância das atividades de cataçăo realizada por inúmeros catadores dispersos pela cidade. Assim, em 2002, a prefeitura instituiu o Programa Sócio-ambiental Cooperativa de Catadores de Material Reciclável, pelo decreto $n^{\circ} .42 .290$, de 15 de agosto de 2002.

Segundo este decreto, o programa deve ser desenvolvido com a participação da sociedade civil, com a finalidade de promover a defesa do meio ambiente, a mudança no comportamento social e a geração de emprego e renda.

Entre os objetivos do programa estão: estimular a geração de renda e emprego; fomentar a formação de cooperativas de trabalho, resgatar a cidadania mediante o reconhecimento do direito básico ao trabalho; promover a educação ambiental; propiciar a defesa do meio ambiente pela coleta seletiva e a reciclagem do lixo; e apoiar as cooperativas de trabalho, visando ao aprimoramento de suas atividades.

Estão incluídas nas ações do programa: o apoio à formação de cooperativas de trabalho; a implementação progressiva de coleta seletiva de lixo, por meio das cooperativas de trabalho de catadores de materiais recicláveis ${ }^{15}$; a triagem e reciclagem de materiais em unidades regionais, que prevê a construção de 31 Centrais de Triagem, a serem operadas pelas próprias cooperativas; e 0 desenvolvimento de atividades de educação ambiental.

\footnotetext{
${ }^{15}$ Segundo este decreto, entende-se por cooperativa o grupo de catadores de material reciclável legalmente constituído, que gerenciará a unidade regional encarregada de coletar, triar, armazenar e comercializar os resíduos.
} 
O órgão responsável pela coordenação do programa é a Secretaria de Serviços e Obras e sua gestão é feita de forma compartilhada por representantes do poder executivo, das cooperativas, das entidades sindicais e da sociedade civil, por uma comissão de apoio que deve acompanhar, avaliar e formular sugestões.

É através da Secretaria de Serviços e Obras que é feito um convênio entre as cooperativas e a prefeitura, com duração de 2 anos, podendo ser renovado.

Para que as cooperativas sejam incluídas neste programa elas devem obedecer a alguns critérios, como a proibição de contratação de empregados para as atividades diretamente associadas à coleta e à reciclagem de resíduos. Todos os trabalhadores, neste caso, devem ser associados à cooperativa e isto implica na proibição de comprar materiais recicláveis de terceiros, como por exemplo, de condomínios. Os materiais recicláveis devem ser doados aos catadores.

Para evitar a dissolução e garantir a continuidade na autonomia das cooperativas, que já atuavam nas atividades de catação antes da implantação do programa da prefeitura, é transferida apenas uma parcela dos respectivos associados de cada cooperativa para o trabalho nas Centrais de Triagem da Prefeitura. Como estas Centrais de Triagem são construidas em diferentes bairros da cidade, participam, em cada central, as cooperativas situadas nas suas proximidades.

Além dos catadores que já atuavam em cooperativas, algumas das centrais incluem também catadores que atuavam individualmente nas ruas. Assim, dentro de cada central é formado um novo grupo que também trabalha de acordo com o sistema cooperativista.

Isto possibilita uma troca de experiência entre os catadores iniciantes e os já experientes no trabalho em grupo. Esta forma de participação dos catadores foi definida durante a discussão para a implantação deste projeto municipal de inclusão dos catadores, que teve ampla participação da sociedade civil e dos representantes das cooperativas. 
O Projeto Vira Lata está inserido neste programa, pela participação de alguns de seus membros na Central de Triagem da Vila Leopoldina, localizada na Lapa, no terreno da Usina de Compostagem da Vila Leopoldina, desde outubro de 2003. O Projeto Vira Lata também atuou na Central de Triagem de Pinheiros, durante o período de fevereiro a agosto de 2004.

Assim, a retirada mensal obtida pelos membros do Projeto Vira Lata, que participam das Centrais de Triagem, é destinada à sede do Projeto e redistribuida igualitariamente entre seus membros. Esta medida foi tomada para garantir a eqüidade na retirada, pois na Central de Triagem, atualmente, a retirada é maior do que a obtida pelos membros que atuam apenas na sede do Projeto Vira Lata.

Desta forma, apesar de participar do programa desenvolvido pela prefeitura, fica garantida a autonomia adquirida pelo Projeto Vira Lata, desde a sua criação, em 1998.

Em 2003, a prefeitura de São Paulo iniciou a cobrança de uma taxa específica para a coleta de resíduos sólidos urbanos. Esta taxa é cobrada de maneira progressiva, conforme a quantidade gerada de lixo que é autodeclarada pelo contribuinte, conforme estabelecido pela Lei Municipal $n^{\circ} .13 .478$ de 2002. A cobrança desta taxa tem como objetivo reduzir a quantidade de resíduos sólidos gerados e destinados aos aterros, além de procurar estimular a participação da população no programa de coleta seletiva de lixo (São Paulo, 2002).

A coleta seletiva de lixo é realizada pela prefeitura, que faz a concessão para a prestação destes serviços a empresas que atuam em determinadas regiōes da cidade. A coleta é feita pelos dois sistemas: porta a porta e por PEV's. Estas empresas coletam e transportam os materiais recicláveis até as Centrais de Triagem. A renda obtida pelos catadores que atuam nestas centrais é obtida pela comercialização destes materiais.

Assim, a receita obtida pelos membros do Projeto Vira Lata provém da retirada dos catadores que atuam nas Centrais de Triagem e 
pela coleta realizada pelo Projeto Vira Lata, com recursos e veículos próprios.

Na sua relação com o mercado de reciclagem, o Projeto Vira Lata realiza venda direta à indústria recicladora, para alguns materiais, no caso o vidro e a garrafa PET. Para os vidros vende diretamente à Indústria Cysper e para o PET à Indústria Eco Fabril. Para os outros materiais a comercialização é feita através de intermediários.

No ano de 2003, o Projeto Vira Lata obteve um importante financiamento da Petrobrás para a execução de um projeto de usina de telhas ecológicas, feita com papéis provenientes de revistas, jornais e papelão de segunda.

Este projeto de usina de telhas ecológicas está incluído numa ampla política social da Petrobrás de incentivar organizaçōes sociais sem fins lucrativos, em todo o país. O Projeto Vira Lata conseguiu a inclusão nesta política da Petrobrás graças à atuação de sua diretoria, que estruturou o plano de propostas para a execução e o andamento da usina de telhas, e com isso obteve a aprovação pelos técnicos da Petrobrás.

Entre estas propostas, estão incluídas, além da usina de telhas, a educaçăo ambiental dos membros do Projeto Vira Lata, a aquisiçăo de uniformes e de itens necessários para manter a segurança no trabalho, como luvas e botas, além de balcões para a separação dos materiais coletados. Também foram incluidos nestas propostas dois veículos: um caminhão para aumentar a capacidade na coleta de materiais recicláveis e uma perua utilizada para o transporte dos catadores até a usina de telhas, que ainda está em fase de construção.

Para a fabricação das telhas, denominadas de telhas fibroasfálticas, o papel utilizado é dissolvido e transformado em placas onduladas que depois recebe uma camada impermeabilizante com cimento asfáltico, CAP20, de fabricação da Petrobrás. Estas telhas apresentam uma durabilidade considerável a um preço bem inferior às telhas comuns. 
O Projeto Vira Lata já prevê a venda destas telhas a cooperativas de habitação, realizando, desta forma, uma necessária integração entre cooperativas de diferentes setores.

A usina de telhas permitirá agregar valor ao material recuperado e iniciar um novo processo de industrialização, com o desenvolvimento de tecnologias adaptadas, na fabricação de produtos para o consumo final. Isto significa uma nova possibilidade para estes catadores, diferente da inclusão precária no mercado de reciclagem, apenas como fornecedores de materiais recicláveis.

Quanto às normas cooperativistas, apesar do Projeto Vira Lata não ser uma cooperativa formal, o trabalho realizado pelos catadores é organizado segundo as práticas cooperativas. O presidente convoca reuniões freqüentes o que garante a autogestão e a participação democrática dos associados nas decisōes de seu próprio trabalho.

Quanto à arrecadação dos fundos para aplicação dos recursos, 0 Projeto Vira Lata não faz reservas para a manutenção de suas atividades.

\subsection{Análise Comparativa dos Dados}

Para a análise comparativa entre as cooperativas de catadores estudadas foram coletados informações e dados referentes ao periodo de janeiro a junho de 2004. Estes dados estão especificados detalhadamente no Anexo $A$, assim como o questionário aplicado nas entrevistas, apresentado no Anexo B.

\subsubsection{Formação e infra-estrutura das cooperativas analisadas}

O Quadro 1 reúne as informações sobre a formação das cooperativas, a infra-estrutura presente e forma de coleta dos materiais recicláveis comercializados. 
QUADRO 1 - Formação, infra-estrutura e origem dos recursos das cooperativas analisadas, de janeiro a junho de 2004.

\begin{tabular}{|c|c|c|c|}
\hline 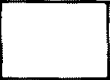 & Cooperyara & Raio de Luz & Vira Lata \\
\hline 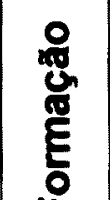 & Iniciativa da Prefeitura & Iniciativa da Prefeitura & $\begin{array}{c}\text { Iniciativa da Organizaçăo } \\
\text { de Moradores do Bairro } \\
\text { Jardim Boa Vista }\end{array}$ \\
\hline$\frac{0}{8}$ & $\begin{array}{c}\text { Galpåo }(300 \mathrm{~m} 2) \text {, refeitório, sala } \\
\text { para escritório, } 2 \text { banheiros. (Pref.) }\end{array}$ & $\begin{array}{c}\text { Galpăo, sala para escritório, } 2 \\
\text { banheiros, copa e cozinha. } \\
\text { (Pref.) }\end{array}$ & $\begin{array}{c}\text { Espaço do antigo } \\
\text { Incinerador de Pinheiros: } \\
\text { com galpão, sala de } \\
\text { escritório; cozinha, } 2 \\
\text { banheiros, balança de } \\
\text { chăo para caminhóes. } \\
\text { (Pref.) } \\
\end{array}$ \\
\hline \multirow{8}{*}{ 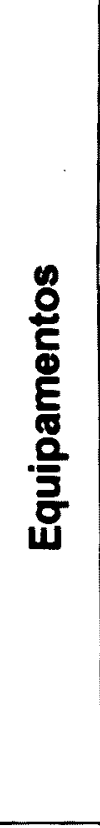 } & Esteira $15 \mathrm{~m}$. (Pref.) & $\ldots$ & $\ldots$ \\
\hline & $\begin{array}{c}2 \text { prensas: } 1 \text { vertical e } 1 \text { horizontal } \\
\text { (Pref.) }\end{array}$ & 3 prensas (Financ. Caixa) & $\begin{array}{l}\text { Utiliza a prensa da Central } \\
\text { de Triagem de Pinheiros } \\
\text { que também está } \\
\text { instalada no espaço do } \\
\text { Antigo Incinerador de } \\
\text { Pinheiros (Pref.) } \\
\end{array}$ \\
\hline & $\ldots$ & 1 empilhadeira (Financ.) & $\cdots$ \\
\hline & $\cdots$ & $\begin{array}{c}2 \text { trituradoras, de plástico e de } \\
\text { papel (Financ.) }\end{array}$ & $\cdots$ \\
\hline & $\cdots$ & 1 caminhăo (Financ.) & $\begin{array}{c}1 \text { caminhăo } 680 \\
\text { (Doaçăo - voluntánios) }\end{array}$ \\
\hline & $\cdots$ & $\cdots$ & $\begin{array}{l}1 \text { caminhåo } 710 \\
\text { (Recursos Petrobrás) }\end{array}$ \\
\hline & $\cdots$ & $\cdots$ & $\begin{array}{c}1 \text { perua } \\
\text { (Recursos Petrobrás) }\end{array}$ \\
\hline & 4 carrinhos transportadores (Pref.) & 3 bicicletas (Financ.) & $\begin{array}{c}1 \text { Topic } \\
\text { (Aquisição Própria) }\end{array}$ \\
\hline \multirow{3}{*}{ 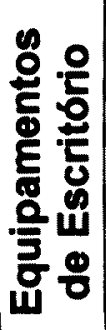 } & $\begin{array}{c}1 \text { computador } \\
\text { (Doaçăo Fund. AlphaVille) }\end{array}$ & $\begin{array}{c}1 \text { computador } \\
\text { (Aquisiçăo Própria) }\end{array}$ & $\cdots$ \\
\hline & $\begin{array}{c}1 \text { impressora } \\
\text { (Aquisiça̋o Própria) }\end{array}$ & $\begin{array}{c}1 \text { impressora } \\
\text { (Encontrada na Coleta) }\end{array}$ & $\cdots$ \\
\hline & $\begin{array}{l}\text { Linha Telefónica } \\
\text { (Aquisiçăoo Própria) }\end{array}$ & $\begin{array}{l}\text { Linha Telefónica } \\
\text { (Aquisiçåo Própria) }\end{array}$ & $\begin{array}{l}\text { Linha Telefónica } \\
\text { (Aquisição Própria) }\end{array}$ \\
\hline 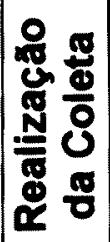 & $\begin{array}{l}\text { Prefeitura pelo sistema } \\
\text { Porta a Porta }\end{array}$ & $\begin{array}{l}\text { Prefeitura por Postos de } \\
\text { Entrega Voluntária - PEV's }\end{array}$ & $\begin{array}{c}\text { Realiza Coleta Própria + } \\
\text { Coleta que provém da } \\
\text { participação nas Centrais } \\
\text { realizada pela Prefeitura } \\
\text { pelo sistema porta a porta } \\
\text { e por PEV"s. }\end{array}$ \\
\hline
\end{tabular}

Fonte: Informaçes coletadas nas cooperativas. Elaborado pela autora.

Obs: (Pref.) - Concessăo de Uso; (Financ.) - Financiamento obtido, via Prefeitura de Săo Bernardo do Campo, a fundo perdido; (Recursos Petrobrás) - Recursos obtidos para o Projeto de Construçăo da Usina de Telhas Ecológicas; (...) - A cooperativa năo possui. 
A análise das informações deste quadro permite observar a relevância do apoio dado pelo poder público para as atividades da Cooperyara, em Barueri, e da Associaçăo Raio de Luz, em São Bernardo do Campo.

A iniciativa para a formação destas cooperativas foi das próprias prefeituras. Estas iniciativas surgiram pelo fechamento dos antigos lixões existentes nestes municípios, onde diversos catadores realizavam suas atividades. Assim, estas cooperativas foram organizadas e incubadas com o objetivo de organizar e valorizar o trabalho de catação urbana.

Estas cooperativas estão incluídas nos programas municipais de coleta seletiva de lixo e o material reciclável utilizado é doado pelas prefeituras.

Além disso, o espaço, os equipamentos para beneficiamento dos materiais recicláveis $\mathrm{e}$ os veículos transportadores têm origem nos recursos da prefeitura, utilizados por concessão de uso. No caso da Associação Raio de Luz estes equipamentos foram obtidos através de um financiamento, a fundo perdido, conseguido por intermediação de técnicos da prefeitura.

Quanto aos equipamentos de escritório, pode-se perceber uma maior autonomia em relação ao apoio dado pelo poder público. A Cooperyara obteve a doação de um computador da Fundação AlphaVille e comprou sua impressora. Já, a Associação Raio de Luz comprou o computador e encontrou a impressora na triagem dos materiais recicláveis.

Quanto à linha telefônica, todas as organizações de catadores conseguem manter suas contas com recursos próprios.

Ao contrário da Cooperyara e da Associação Raio de Luz, a iniciativa para a formação do Projeto Vira Lata provém de uma organização de moradores de bairro.

O Projeto Vira Lata foi fundado em 1998, com sua sede no Bairro Jardim Boa Vista. Em 2002, através de concessão de uso, realizada pela 
prefeitura de São Paulo, a sede foi transferida para um espaço bem maior, onde antigamente funcionava o Incinerador de Pinheiros.

Somente a partir de outubro de 2003, o Projeto Vira Lata passou a contar com um apoio mais efetivo da prefeitura, que desenvolveu um programa para inclusão das cooperativas de catadores na coleta seletiva de lixo, pela construção de Centrais de Triagem, onde parte dos membros do Projeto Vira Lata fazem a triagem dos materiais coletados pela prefeitura.

Apesar deste apoio do poder público, o Projeto Vira Lata manteve a sua autonomia, continuando a realizar a coleta de materiais recicláveis, em condominios e residências da região, com recursos e veículos próprios

Estes veículos utilizados para a coleta foram conseguidos por doações, pelo projeto de usinas de telhas financiado pela Petrobrás e a perua Topic que foi adquirida com recursos próprios.

\subsubsection{Estrutura administrativa das cooperativas analisadas}

$\mathrm{Na}$ Tabela 2, são apresentados o número de associados e 0 cálculo da média mensal de associados, em cada cooperativa analisada.

TABELA 2 - Número de Catadores e Cálculo da Média Mensal de Catadores, em cada cooperativa analisada, 2004.

\begin{tabular}{l|c|c|c|c|c|c|c}
\hline \hline Cooperativas & Janeiro & Fevereiro & Março & Abril & Maio & Junho & $\begin{array}{c}\text { Média } \\
\text { Mensal }\end{array}$ \\
\hline \hline Cooperyara & 31 & 31 & 34 & 36 & 36 & 35 & 34 \\
\hline Raio de Luz & 24 & 24 & 24 & 24 & 26 & 26 & 25 \\
\hline Vira Lata & 44 & 41 & 50 & 50 & 47 & 45 & 46 \\
\hline Sede Vira Lata* & 38 & 29 & 35 & 32 & 29 & 27 & 32 \\
\hline Centrais de Triagem* & 6 & 12 & 15 & 18 & 18 & 18 & 14 \\
\hline
\end{tabular}

Fonte: Informações coletadas nas cooperativas. Elaborada pela autora.

* Especificação da participação dos membros do Projeto Vira Lata no programa da prefeitura de São Paulo.

Na Tabela 2 é observada a evolução no número de associados em cada cooperativa. A Associação Raio de Luz apresenta o menor fluxo entre seus integrantes, pois, durante o período analisado, nenhum 
nenhum membro se retirou da sociedade, e a partir de maio de 2004, ingressaram duas novas pessoas.

Esta tabela revela também, no caso do Projeto Vira Lata, a quantidade de seus integrantes que atuavam na própria sede e a quantidade de integrantes que atuavam nas Centrais, pelo programa realizado pela Prefeitura de São Paulo.

Assim, apesar da média mensal no número de catadores do Projeto Vira Lata ser maior, o número de catadores que trabalhavam diretamente na sede se compara ao número de catadores das outras cooperativas analisadas.

Para analisar a coordenação realizada no trabalho destes catadores foram reunidas as informações demonstradas no Quadro 2.

QUADRO 2 - Coordenação do trabalho nas cooperativas de catadores analisadas, de janeiro a junho de 2004.

\begin{tabular}{|c|c|c|}
\hline Cooperyara & Raio de Luz & Vira Lata \\
\hline presidente & presidente & coordenador geral \\
\hline vice-presidente & vice-presidente & vice-coordenador geral \\
\hline tesoureiro & tesoureiro & coordenador 1a. Triagem \\
\hline secretário & secretário & coordenador papel \\
\hline diretor comercial & vice-tesoureiro & coordenador vidros \\
\hline & vice-secretário & coordenador plásticos \\
\hline & & coordenador prensa \\
\hline
\end{tabular}

Fonte: Informaçőes coletadas nas cooperativas. Elaborado pela autora.

Existe uma grande semelhança na coordenação dos trabalhos entre a Cooperyara e a Associação Raio de Luz, que seguem a estrutura formal de uma cooperativa. A Associação Raio de Luz, apesar de ainda não estar formalizada como uma cooperativa, as atividades de incubação realizadas pela prefeitura incluem a dinâmica do trabalho cooperativo.

Tanto na Cooperyara quanto na Associação Raio de Luz, todos os cargos são ocupados por seus respectivos associados e o prazo de mandato, para cada chapa eleita, é de dois anos. 
Quanto à reeleição, no estatuto da Cooperyara existe uma cláusula permitindo a reeleição. Já, no estatuto da Associação Raio de Luz é definido que cada candidato poderá ser reeleito apenas uma vez, ou seja, realizar apenas dois mandatos consecutivos, para o mesmo cargo.

O Projeto Vira Lata, como não se constitui como uma cooperativa formal não segue uma estrutura formal para a coordenação do trabalho. Durante as discussões entre a diretoria e os catadores, foi elaborada uma estrutura diferente, de acordo com as necessidades existentes. Assim, no Projeto Vira Lata existe um cargo de coordenação para cada etapa do processo de separação, triagem e beneficiamento dos materiais recuperados.

Cabe lembrar que, apesar de não seguir a estrutura de coordenação formal de uma cooperativa, a prática do trabalho entre os catadores segue a conduta proposta pelo cooperativismo, com autogestão do próprio trabalho, participação democrática e divisão igualitária das receitas obtidas.

\subsubsection{Apoio externo gerencial}

Para as orientaçōes necessárias nas suas atividades, as cooperativas analisadas recebem apoio gerencial externo realizado ou por voluntários da sociedade civil ou por técnicos da prefeitura. Estes apoios são apresentados no Quadro 3.

QUADRO 3 - Apoio gerencial externo nas cooperativas de catadores analisadas, de janeiro a junho de 2004.

\begin{tabular}{|c|c|c|}
\hline Cooperyara & Raio de Luz & Vira Lata \\
\hline $\begin{array}{c}\text { Colaboraçăo de } 2 \text { voluntários } \\
\text { da Fundaçăo AlphaVille (um } \\
\text { deles já trabalhou na } \\
\text { Prefeitura como um dos } \\
\text { mentores do projeto de } \\
\text { formaçåo da cooperativa); } \\
\text { Assessoria de } 1 \text { funcionário } \\
\text { da Prefeitura }\end{array}$ & $\begin{array}{c}\text { Acompanhamento de } \\
\text { uma advogada e uma } \\
\text { assistente social, que såo } \\
\text { funcionárias da prefeitura. }\end{array}$ & $\begin{array}{l}\text { Uma Diretoria composta } \\
\text { por } 3 \text { cargos: Diretor- } \\
\text { Presidente, Diretor } \\
\text { Tesoureiro e Diretor de } \\
\text { Eventos. Estes diretores } \\
\text { realizam seus cargos por } \\
\text { trabalho voluntário. }\end{array}$ \\
\hline
\end{tabular}

Fonte: Informaçס̄es fornecidas pelas cooperativas. Elaborado pela autora. 
A Cooperyara recebe apoio gerencial de voluntários da Fundação AlphaVille e de funcionários da prefeitura. Este auxilio se faz pelo apoio dado no processo eleitoral para os cargos da cooperativa, nos processos de renegociaçăo do contrato com a prefeitura, pela doação de um computador pela Fundação AlphaVille que também promove a educação ambiental para a participação da população na coleta seletiva realizada pelo município. Além disso, a Fundaçăo AlphaVille estimula a participação dos associados da Cooperyara em eventos realizados no municípios, onde os catadores podem divulgar o seu trabalho

Apesar da Cooperyara não ter passado por um período de incubação específico foram realizadas atividades esporádicas, como por exemplo, cursos do SEBRAE sobre cooperativismo e triagem dos materiais.

Na Associação Raio de Luz, o auxilio é realizado exclusivamente por técnicos da prefeitura. Esta associação passou por um rico processo de incubação, iniciado em 2000, e que será encerrado apenas quando as atividades dos catadores estiverem amadurecidas. Assim, não foi estabelecido um prazo para o encerramento das atividades de incubação.

No Projeto Vira Lata este apoio é realizado de maneira bastante dinâmica pelos membros da diretoria, responsável pelas diferentes parcerias entre os catadores e a sociedade civil que doam materiais recicláveis para a cooperativa, além da execução de um projeto de usina de telhas ecológicas.

Cabe ressaltar, que em todos estes casos analisados, os catadores citaram outros apoiadores externos. Entretanto eles não foram incluídos por não apresentarem uma regularidade representativa.

\subsubsection{A busca pela participacão da sociedade civil}

As atividades realizadas pelas cooperativas analisadas na busca pela conscientização e envolvimento da sociedade civil do trabalho realizado por eles é demonstrado no Quadro 4. 
QUADRO 4 - Atividades realizadas para estimular a participação da sociedade civil no trabalho dos catadores, de janeiro a junho de 2004.

\begin{tabular}{|c|c|c|}
\hline Cooperyara & Raio de Luz & Vira Lata \\
\hline $\begin{array}{c}\text { Rarticipaçăo em eventos } \\
\text { e palestras que envolvem } \\
\text { um público grande, onde } \\
\text { os catadores divulgaram } \\
\text { seu trabalho. }\end{array}$ & $\begin{array}{c}\text { indústrias da regiăo que doam } \\
\text { reciéveis para a Associação } \\
\text { além da coleta feita pelos } \\
\text { catadores através de } \\
\text { bicicletas nas residências } \\
\text { próximas à sua sede. }\end{array}$ & $\begin{array}{c}\text { Realiza educaçăo ambiental } \\
\text { na região e palestras em } \\
\text { escolas. Além da divulgação } \\
\text { pela internet da contabilidade } \\
\text { das atividades realizadas. }\end{array}$ \\
\hline
\end{tabular}

Fonte: Informaçőes fornecidas pelas cooperativas. Elaborado pela autora.

$\mathrm{Na}$ Cooperyara e no Projeto Vira Lata estas atividades foram realizadas graças ao apoio externo dado pelos voluntários. No caso da Cooperyara por voluntários da Fundação AlphaVille e no Projeto Vira Lata pela atuação do trabalho realizado por sua diretoria.

Já, as atividades de parcerias com as indústrias, na Associação Raio de Luz, foram realizadas por livre iniciativa de seus catadores. A coleta pelas bicicletas foi estimulada pelos funcionários da prefeitura.

\subsubsection{Aspectos Financeiros}

Para analisar os aspectos operacionais e financeiros foram levantados dados sobre: a quantidade de material triado comercializado e a composição destes materiais; a receita obtida pela comercialização; o valor da retirada dos catadores; e os custos arcados pelas cooperativas de catadores pesquisadas. Estes dados estão demonstrados nas tabelas do Anexo A.

Com estes dados coletados foram elaborados indicadores para facilitar a análise entre as cooperativas estudadas. Foram elaborados três indicadores sobre: o Material Comercializado por catador; o Percentual das Despesas sobre as Receitas; e a Composição dos Materiais Comercializados. 
Indicador 1 - Material Comercializado, por catador.

Este indicador revela a produtividade do trabalho realizado por catador, nas três cooperativas analisadas. O cálculo é feito pela média mensal da quantidade de material comercializado pela média mensal do número de catadores.

Ind. 1 = Quantidade de Material Comercializado - Média Mensal (Kg) Número de Catadores - Média Mensal

TABELA 3 - Média Mensal de Material Comercializado, por catador, Janeiro a Junho de 2004.

\begin{tabular}{l|c|c|c}
\hline \hline Cooperativas & $\begin{array}{c}\text { Número de } \\
\text { Catadores } \\
\text { (Média Mensal) }\end{array}$ & $\begin{array}{c}\text { Material } \\
\text { Comercializado } \\
(\mathrm{kg}) \\
\text { (Média Mensal) }\end{array}$ & $\begin{array}{c}\text { Quantidade de } \\
\text { Material } \\
\text { Comercializado } \\
\text { por Catadores } \\
(\mathrm{kg})\end{array}$ \\
\hline \hline Cooperyara & 34 & 84.427 & 2.483 \\
\hline Raio de Luz & 25 & 43.103 & 1.724 \\
\hline Vira Lata* & 32 & 39.124 & 1.223 \\
\hline
\end{tabular}

Fonte: Informações coletadas nas cooperativas. Elaborada pela autora.

* Dados referentes apenas à sede do Projeto Vira Lata, sem incluir o trabalho realizado nas Centrais de Triagem da prefeitura.

Este indicador revela que a Cooperyara por ser a única cooperativa de catadores incluída no programa da prefeitura de Barueri para realizar a triagem dos materiais coletados e por possuir uma esteira para realização desta tarefa (Quadro 1), equipamento não disponível nas outras duas cooperativas, consegue melhores resultados na quantidade triada de materiais recicláveis.

A Associação Raio de Luz é inserida no programa juntamente com a Associação Refazendo. Além disso, a coleta em Barueri é realizada porta a porta em $100 \%$ do município, e em São Bernardo do Campo, é feita por Ecopontos (PEV's), o que diminui a quantidade coletada de resíduos recicláveis. 
Como o Projeto Vira Lata realiza com recursos próprios a coleta de materiais realizada na sede, a quantidade de materiais vendidos é a menor observada entre as três organizaçōes de catadores analisadas.

A influência na quantidade de material coletada é refletida na receita adquirida em cada cooperativa de catadores, conforme apresentado na Tabela 4:

TABELA 4 - Receita Arrecadada por Mês e Média Mensal, em cada cooperativa analisada, em Reais, 2004.

\begin{tabular}{c|c|c|c|c|c|c|c}
\hline Cooperativas & Jan & Fev & Mar & Abr & Mai & Jun & $\begin{array}{c}\text { Média } \\
\text { Mensal }\end{array}$ \\
\hline Cooperyara & $22.748,86$ & $16.268,88$ & $20.279,66$ & $21.036,56$ & $21.991,28$ & $20.949,37$ & $20.545,77$ \\
\hline Raio de Luz & $15.195,85$ & $11.933,70$ & $14.148,37$ & $9.581,73$ & $11.189,84$ & $11.230,95$ & $12.213,41$ \\
\hline Vira Lata & $13.492,85$ & $12.279,92$ & $14.530,21$ & $16.728,23$ & $13.569,89$ & $14.534,65$ & $14.189,29$ \\
\hline Sede Vira Lata * & $12.249,85$ & $9.290,08$ & $11.171,51$ & $11.761,03$ & $9.618,78$ & $9.582,16$ & $10.612,24$ \\
\hline $\begin{array}{c}\text { Centrais de } \\
\text { Triagem * }\end{array}$ & $1.243,00$ & $2.989,84$ & $3.358,70$ & $4.967,20$ & $3.951,11$ & $4.952,49$ & $3.577,06$ \\
\hline
\end{tabular}

Fonte: Informações coletadas nas cooperativas. Elaborada pela autora.

* Especificação da receita adquirida pela participação do Projeto Vira Lata no programa da prefeitura de São Paulo.

A Cooperyara por conseguir a maior quantidade de materiais obtém a maior receita, entre as cooperativas de catadores analisadas.

É demonstrada também a evolução na receita adquirida pelo Projeto Vira Lata pela participação no programa da prefeitura.

\section{Indicador 2 - Percentual de Despesas sobre as Receitas.}

Este indicador revela o peso das despesas realizadas sobre as receitas arrecadadas, em porcentagem. Para o cálculo deste indicador foram utilizadas as médias mensais das receitas e despesas, em cada cooperativa analisada. As tabelas referentes aos dados sobre as despesas estão em anexo (Tabelas 8, 9, 10 e 11). Cabe ressaltar que, para obter 0 montante das despesas realizadas as retiradas dos catadores não foram consideradas como custos. 
Ind. 2 = Despesas - Média Mensal (R\$) $\times 100$

Receitas - Média Mensal (R\$)

Tabela 5 - Percentual das Despesas sobre a Receita, nas cooperativas analisadas, Janeiro a Junho de 2004.

\begin{tabular}{l|c|c|c}
\hline \hline \multicolumn{1}{c|}{ Cooperativas } & $\begin{array}{c}\text { Receita } \\
(\mathrm{R} \$) \\
\text { (Média Mensal) }\end{array}$ & $\begin{array}{c}\text { Despesas } \\
\text { (R\$) } \\
\text { (Média Mensal) }\end{array}$ & $\begin{array}{c}\text { \% Despesas } \\
\text { sobre Receitas }\end{array}$ \\
\hline \hline Cooperyara & $20.545,77$ & 880,00 & 4,28 \\
\hline Raio de Luz & $12.213,41$ & 715,30 & 5,86 \\
\hline Vira Lata & $14.189,29$ & $3.554,90$ & 25,05 \\
\hline
\end{tabular}

Fonte: Informações coletadas nas cooperativas. Elaborada pela autora.

Este indicador demonstra que o fato de realizar a coleta com recursos próprios implica em custos maiores arcados pelo Projeto Vira Lata, em que as despesas atingem um percentual de $25 \%$ sobre as receitas arrecadadas, valor bem acima do observado nas demais cooperativas analisadas.

As despesas realizadas no Projeto Vira Lata e o percentual gastos com Combustíveis e Consertos dos Veículos são apresentadas na Tabela 6, abaixo:

TABELA 6 - Despesas Realizadas pelo Projeto Vira Lata e Percentual dos gastos realizados com os veículos e na coleta pelo Projeto Vira Lata, 2004.

\begin{tabular}{|c|c|c|c|c|c|c|}
\hline Despesas Projeto Vira Lata & Janeiro & Fevereiro & Março & Abril & Maio & Junho \\
\hline Telefone & 339,05 & $\ldots$ & 265,36 & $\ldots$ & 83,66 & $\ldots$ \\
\hline Mercado e Diversas & $1.727,53$ & 843,17 & 446,32 & 297,41 & 772,25 & 787,52 \\
\hline Transporte & $\ldots$ & $\ldots$ & $\ldots$ & 211,60 & $\ldots$ & $\ldots$ \\
\hline Fita de prensa & $\ldots$ & $\ldots$ & 205,00 & 113,22 & $\ldots$ & $\ldots$ \\
\hline Combustível & $2.012,14$ & $1.563,10$ & $1.248,39$ & $2.081,57$ & $1.687,45$ & $1.724,92$ \\
\hline Despesas diversas veículos & 242,20 & 807,00 & $1.148,00$ & $1.253,90$ & $1.268,62$ & 200,00 \\
\hline TOTAL DAS DESPESAS & $4.320,92$ & $3.213,27$ & $3.313,07$ & $3.957,70$ & $3.811,98$ & $2.712,44$ \\
\hline $\begin{array}{l}\text { Percentual das Despesas } \\
\text { com Combustivel e Velculos } \\
\text { Sobre o Total das Despesas }\end{array}$ & 52,17 & 73,76 & 72,33 & 84,28 & 77,55 & 70,97 \\
\hline
\end{tabular}

Fonte: Informaçðes coletadas no Projeto Vira Lata. Elaborada pela autora. 
Pelos dados apresentados na Tabela 6 , o peso das despesas realizadas com a coleta dos materiais recicláveis atinge uma média mensal, para o período analisado, de $72 \%$ sobre o total das despesas. Este alto peso realizado nas atividades de coleta no Projeto Vira Lata é refletido no valor da retirada de seus catadores.

A Tabela 7 apresenta a evolução no valor da retirada por hora, para as três cooperativas analisadas.

Tabela 7 - Valor da Retirada, por hora trabalhada, para cada catador, e média mensal, nas cooperativas analisadas, 2004.

\begin{tabular}{l|c|c|c|c|c|c|c}
\hline Cooperativas & Janeiro & Fevereiro & Março & Abril & Maio & Junho & $\begin{array}{c}\text { Média } \\
\text { Mensal }\end{array}$ \\
\hline \hline Cooperyara & 2,80 & 2,71 & 2,94 & 3,27 & 3,68 & 3,64 & 3,17 \\
\hline Raio de Luz & 3,55 & 3,00 & 3,02 & 2,21 & 2,51 & 2,66 & 2,83 \\
\hline Vira Lata & 0,75 & 1,00 & 1,00 & 1,00 & 1,13 & 1,13 & 1,00 \\
\hline
\end{tabular}

Fonte: Informaçőes coletadas nas cooperativas. Elaborada pela autora.

Esta tabela revela a diferença existente entre 0 valor da hora trabalhada, entre as cooperativas analisadas que recebem apoio do poder público na coleta de materiais, no caso a Cooperyara e a Associação Raio de Luz e as cooperativas que atuam autonomamente, no caso o Projeto Vira Lata.

Assim, o indicador 2 demonstra a relevância do apoio do poder público, dado especificamente pela coleta e doação dos materiais recicláveis, que reduz consideravelmente as despesas realizadas pelos catadores.

\section{Indicador 3 - Composição do Material Comercializado}

Este indicador revela o percentual de cada material sobre a quantidade total de materiais triados comercializados pelas organizações de catadores pesquisadas. Este indicador năo foi calculado sobre a méida mensal, mas sobre a quantidade total de materiais comercializados nos 6 meses analisados, em cada organizaçăo de catadores. 
Ind. 3 = Quantidade Total por Tipo de Material Comercializado $(\mathrm{Kg}) \times 100$ Total de Material Comercializado (Kg)

Tabela 8 - Composição do Material Total Comercializado, em porcentagem, por cooperativa analisada, janeiro a junho de 2004.

\begin{tabular}{l|c|c|c}
\hline Material & Cooperyara & Raio de Luz & Vira Lata \\
\hline \hline Papel & 26,80 & 29,59 & 47,01 \\
\hline Papelåo & 21,89 & 14,10 & 14,27 \\
\hline Vidros & 19,25 & 10,25 & 20,76 \\
\hline Plástico Duro & 7,69 & 6,88 & 4,02 \\
\hline Plástico Mole & 4,87 & 8,09 & 2,46 \\
\hline PET & 5,65 & 4,10 & 3,55 \\
\hline Metais & 6,31 & 21,23 & 5,40 \\
\hline Longa Vida & 7,10 & 4,60 & 2,09 \\
\hline Alumínio & 0,45 & 0,97 & 0,42 \\
\hline Outros & 0,01 & 0,18 & 0,03 \\
\hline TOTAL & 100,00 & 100,00 & 100,00 \\
\hline
\end{tabular}

Fonte: Informaçð̃es coletadas nas cooperativas. Elaborada pela autora.

Este indicador revela algumas diferenças na composiçăo do material vendido entre as cooperativas.

Os altos índices de papelão e embalagens de Longa Vida, na Cooperyara, podem ser justificados pela localização próxima a condomínios residenciais de alto padrão de consumo.

No caso da Associação Raio de Luz, os altos níveis de sucata são justificados por doações realizadas pela prefeitura.

O caso do papel, no Projeto Vira Lata, deriva de doaçōes feitas por empresas, como a Editora Globo e a Associação Comercial de São Paulo.

\subsubsection{Inserção no Mercado de Reciclagem}

Para observar a relação das cooperativas com os outros agentes que atuam no mercado informal de reciclagem, intermediários e sucateiros, e também para verificar a realização da venda de materiais 
diretamente à indústria recicladora, foram coletados os dados sobre 0 preço de venda obtido para cada material, apresentados na Tabela 9.

Tabela 9 - Preço Médio de Venda, por Quilo e Tipo de Material, em cada cooperativa analisada, janeiro a junho de 2004.

\begin{tabular}{l|c|c|c}
\hline Material & $\begin{array}{c}\text { Cooperyara } \\
\text { (R\$) }\end{array}$ & $\begin{array}{c}\text { Raio de Luz } \\
\text { (R\$) }\end{array}$ & $\begin{array}{c}\text { Vira Lata } \\
\text { (R\$) }\end{array}$ \\
\hline \hline Alumínio & 3,40 & 3,55 & 3,50 \\
\hline Papel & 0,22 & 0,19 & 0,24 \\
\hline Papelåo & 0,17 & 0,21 & 0,21 \\
\hline PET & 0,78 & 0,77 & $\mathbf{0 , 8 5}$ \\
\hline Plástico Duro & 0,44 & 0,48 & $\mathbf{0 , 6 6}$ \\
\hline Plástico Mole & 0,45 & 0,31 & 0,39 \\
\hline Vidros & 0,06 & 0,08 & $\mathbf{0 , 1 4}$ \\
\hline Metais & 0,26 & 0,29 & 0,31 \\
\hline Longa Vida & 0,15 & 0,14 & 0,18 \\
\hline
\end{tabular}

Fonte: Informaçøes fornecidas pelas cooperativas. Elaborada pela autora.

As principais diferenças destacadas são explicadas pela venda direta à indústria recicladora. No Projeto Vira Lata, este é o caso do PET e do Plástico Duro, que são vendidos para a Indústria Eco Fabril, e dos Vidros, vendidos para a Indústria Cysper.

\subsubsection{Cumprimento das Normas Cooperativistas}

O sistema cooperativista possui diversas diretrizes que 0 caracterizam como uma forma alternativa de organizar a produção, pela apropriação coletiva do capital e a participação igualitária no processo de tomada de decisões. Para isto, é necessário que as cooperativas cumpram as normas estabelecidas por este sistema.

Em todas as organizações de catadores analisadas nesta pesquisa é amplo o apoio dado por agentes externos. Mas, apesar deste apoio recebido foi observada a autogestão do próprio trabalho e a participação democrática nas decisões, principalmente no trabalho rotineiro e em grupo, realizado dentro destas cooperativas.

Neste processo de construção do trabalho em grupo é comum aparecerem "lideres" ou "gestores", devido às características pessoais de 
cada um, mas estas pessoas não são vistas e não são tratadas como "chefes", mas como centralizadores das decisōes tomadas e discutidas em grupo. Estas observações puderam ser realizadas durante as visitas e entrevistas realizadas.

Em relação aos fundos para aplicação dos recursos, o Fundo de Reserva e o FATES - Fundo de Assistência Técnica, Educacional e Social, previstos no sistema cooperativistas, segue as informaçōes obtidas, apresentadas na Tabela 10:

Tabela 10 - Destinação das sobras financeiras, em cada cooperativa analisada, em Reais, 2004.

\begin{tabular}{c|c|c|c|c|c|c|c}
\hline Cooperativas & $\begin{array}{c}\text { Destinação } \\
\text { das sobras }\end{array}$ & Janeiro & Fevereiro & Março & Abril & Maio & Junho \\
\hline Cooperyara & INSS & $1.612,00$ & $1.612,00$ & $1.768,00$ & $1.872,00$ & $1.872,00$ & $1.820,00$ \\
\hline Raio de Luz & $\begin{array}{c}\text { Fundo de } \\
\text { Reserva }\end{array}$ & $\ldots$ & 498,30 & 796,70 & $-146,83$ & 195,96 & $\ldots$ \\
\hline Vira Lata & $\begin{array}{c}\text { Saldo em } \\
\text { Conta Corrente }\end{array}$ & $-139,90$ & 62,03 & 684,34 & 178,53 & $2.428,94$ & $1.617,35$ \\
\hline
\end{tabular}

Fonte: Informaçøes coletadas nas cooperativas. Elaborada pela autora.

(...) Dado năo Disponível.

A Cooperyara, atualmente nāo arrecada recursos para a constituição do Fundo de Reserva, nem do FATES, no entanto todos os seus associados contribuem regularmente para a previdência pública social, pelo INSS. É a única cooperativa analisada que recolhe INSS, resultado da atuação do apoio externo na conscientização dos catadores sobre esta necessidade e da elevada retirada obtida por seus associados.

Na Associação Raio de Luz, o Fundo de Reserva está ativo, sobre $10 \%$ da receita bruta, durante os exercicios de cada mês. Este recurso é destinado a pagar as despesas do mês corrente e o restante é aplicado na conta corrente da própria Associação. Esta regularidade na administração dos recursos revela o êxito do amplo trabalho de incubação e capacitação, realizado pela prefeitura de São Bernardo do Campo.

Já, o Projeto Vira Lata não realiza a constituição de nenhum destes fundos, em virtude do montante das despesas arcadas, e pela 
imprevisibilidade destes custos, já que, constantemente, săo realizados gastos para consertos e manutenção dos veículos utilizados na coleta.

Cabe fazer uma observação sobre as elevadas sobras obtidas durante o mês de maio, de R\$ 2.428,94, no Projeto Vira Lata. Estas sobras são provenientes de um trabalho realizado para o Sesc-Interlagos, de beneficiamento, como lavagem e prensagem, de plásticos utilizados numa exposição. Este trabalho elevou as sobras para o mês de maio que também teve reflexo no mês de junho, com uma sobra de $\mathrm{R} \$ 1.617,35$. Estas sobras posteriormente foram utilizadas para pagar algumas dividas e o restante foi dividido igualmente entre os catadores, em meses posteriores ao período utilizado para a análise dos dados.

\subsection{Discussão dos Resultados}

Pela pesquisa de campo realizada pôde-se detectar alguns dos aspectos que colaboram para uma melhor estruturação das atividades realizadas pelas cooperativas de catadores estudadas, que estão incluídas nos programas municipais de coleta seletiva de lixo.

\subsubsection{0 apoio operacional na coleta dos materiais recicláveis}

O estudo de caso realizado nas três cooperativas de catadores da Região Metropolitana de São Paulo, analisadas nesta pesquisa, demonstrou que a realização da coleta de materiais recicláveis exige um grande investimento e a doação destes materiais pela prefeitura é um fator relevante para a estruturação de suas atividades.

A Cooperyara, entre as coperativas analisadas, é a que consegue comercializar a maior quantidade de materiais, e com isso os seus catadores possuem uma elevada retirada. Isto pode ser justificado pelo fato dela ser a única cooperativa a receber os materiais coletados pela prefeitura municipal de Barueri e, além disso, a prefeitura realizou a concessão de uso de uma esteira mecânica para a triagem dos materiais. 
Já, no Projeto Vira Lata, o fato de realizar a coleta com recursos próprios implica no aumento das despesas. $\mathrm{O}$ gasto com combustível e com os veículos utilizados na coleta representa uma média mensal de $72 \%$ no total das despesas realizadas por estes catadores (Ver Tabela 6).

Além da doação de materiais, a prefeitura faz concessão de uso do espaço e dos equipamentos utilizados pelos catadores. Este apoio operacional tem como principal objetivo melhorar a organizaçăo do trabalho dos catadores para que eles realizem a comercialização conjunta dos materiais, agregando valor ao preço dos materiais.

Apesar disto, as cooperativas que trabalham exclusivamente com materiais recicláveis doados pela prefeitura, no caso a Cooperyara e a Associaçăo Raio de Luz, não realizam a venda direta para a indústria para nenhum tipo de material triado. O Projeto Vira Lata, devido à atuação de sua diretoria, consegue realizar a venda direta para a indústria, no caso do vidro do plástico duro e garrafas PET e por isso consegue um maior valor no preço de venda destes materiais.

\subsubsection{O apoio na organização e consolidação do trabalho cooperativo}

Um fator relevante no trabalho dos catadores é o apoio gerencial dado tanto pela prefeitura quanto pela sociedade civil. Nas três cooperativas analisadas nesta pesquisa, este apoio é fundamental e, inclusive, responsável pela iniciativa de organizar 0 trabalho dos catadores pela economia solidária.

Segundo Souza (2002), é comum estas iniciativas da economia solidária estarem ligadas ou receberem apoio externo de organizaçōes sociais, igrejas, associaçōes de moradores de bairro e prefeituras, o que pode provocar uma certa confusão entre trabalho profissional e trabalho voluntário, às vezes, durante toda a existência do empreendimento (SOUZA, 2002 citado por SABBAG, 2003). 
Graças a este apoio dado aos catadores, nas três cooperativas analisadas, a coordenação do trabalho está solidificada pelo trabalho cooperativo. A divisão igualitária das receitas, a participação democrática dos catadores e a autogestão do trabalho interno está presente na rotina dos catadores.

Foi observado também que, o apoio da prefeitura nas atividades de incubação garantem uma estruturação mais formal do trabalho cooperativo entre os catadores. Já, o apoio dado pela organização de moradores de bairro, para o Projeto Vira Lata, resulta numa organização informal, mas que apesar disto, garante os princípios cooperativistas entre os catadores envolvidos nesta iniciativa.

Entretanto, o Projeto Vira Lata recebe um apoio mais dinâmico, dado pela sua diretoria, que atualmente está implantando uma usina de telhas ecológicas.

Isto ressalta que apesar das atividades de incubação das prefeituras obterem êxito na organização formal do trabalho cooperativo, estas atividades ainda são tímidas na busca por inovação no trabalho dos catadores. Frente à valorização econômica da reciclagem é necessário repensar estas atividades de incubação realizada pelas prefeituras.

Cabe ressaltar aqui, que uma das normas cooperativistas é a manutenção da autonomia de trabalho de uma cooperativa, seja em relação ao Estado, seja em relação a qualquer outra entidade.

Estes apoios são extremamente necessários para o desenvolvimento e até para a origem destas cooperativas, entretanto deve-se reavaliar as atividades de incubação para que os catadores busquem outras formas de apoio, garantindo uma maior autonomia no gerenciamento e na inovação de seu próprio trabalho. 


\subsubsection{A participação da sociedade civil}

Quanto à busca pela participação da sociedade civil no trabalho realizado pelos catadores, o apoio dado pela diretoria do Projeto Vira Lata, garante uma ampla interlocução com a sociedade civil, promovendo palestras para a promoçăo da coleta seletiva em escolas, condomínios, residências e comércios, na busca pela doaçăo de materiais recicláveis. Esta participaçăo da sociedade é consolidada por um trabalho transparente na divulgação da contabilidade do Projeto Vira Lata, que é feita mensalmente, via e-mail, a todos os seus colaboradores.

$\mathrm{Na}$ Cooperyara e na Associaçăo Raio de Luz, apesar de existirem atividades que envolvam a participaçăo da sociedade civil, estas atividades são mais esporádicas e menos enfatizadas.

Esta integração com a sociedade civil é necessária para que o trabalho dos catadores seja reconhecido pela sociedade. Segundo a pesquisa feita por Bringhenti (2004), não é feita a associação da atividade dos catadores com a coleta seletiva pela população entrevistada, até mesmo em programas municipais que incluem estas cooperativas, numa coleta seletiva solidária. A autora justifica este resultado pelo fato de que a população não reconhece a atividade do catador como uma profissão, ou um trabalho, mas uma maneira de sobrevivência para pessoas que estão marginalizadas da sociedade.

Isto ressalta o caráter assistencialista das políticas públicas de inclusão dos catadores, através da geração de renda e trabalho pela doação de materiais recicláveis.

Este é um fator que dificulta a autonomia das cooperativas em relação ao Estado e que também provoca o não reconhecimento da população pelo trabalho realizado pelos catadores.

Este problema pode ser contornado pela informação e ênfase do papel que os catadores realizam para a obtenção dos altos índices de reciclagem atingidos no país. É um trabalho precário e desvalorizado, que começa a ser reconhecido, mas que precisa ser divulgado nos programas 
de coleta seletiva, que tenham por objetivo consolidar o trabalho realizado pelos catadores.

"O trabalho não é simplesmente a realização de determinada função ou tarefa, mas marca o pertencimento a uma comunidade distribuidora de prerrogativas e de privilégios que asseguram um estatuto social para o trabalho. Graças a essa dignidade coletiva, a profissão, e não o indivíduo, é proprietária e reconhecida num conjunto hierárquico" (CASTEL, 1998, p.155).

Como visto, a atuaçăo do Projeto Vira Lata que se faz com uma maior interlocução com a sociedade civil provoca a consolidação e o reconhecimento da sociedade pelo trabalho dos seus catadores e, devido a isto, está sendo implantada uma usina de telhas ecológicas, num projeto financiado pela Petrobrás.

Uma interlocução maior com a sociedade civil, além de promover o reconhecimento do trabalho realizado pelos catadores, aumenta as possibilidades de realizar novas parcerias, também fora do Estado. 


\section{Conclusão}

Esta pesquisa teve por objetivo identificar a organização das cooperativas de catadores de materiais recicláveis, e as relações existentes entre estas cooperativas com o poder público municipal, com o mercado de reciclagem e com a sociedade civil. Para isto, foi realizado um estudo de caso em três cooperativas da RMGSP, que estão inseridas nos respectivos programas municipais de coleta seletiva de lixo. Desta forma, pôde-se observar os principais aspectos que auxiliam e que dificultam a consolidação do trabalho realizado por estes catadores.

Nas três cooperativas analisadas, pôde-se observar que o apoio dado ou pelo Estado ou por organizações da sociedade civil é um fator preponderante para organizar o trabalho destes catadores.

Nos municípios de Barueri e de São Bernardo do Campo, a iniciativa para a formação das cooperativas surgiu pela prefeitura, com o objetivo de valorizar o trabalho dos catadores, após o fechamento dos antigos lixões. No Projeto Vira Lata, em São Paulo, está iniciativa surgiu de uma organização de moradores de bairro, para gerar trabalho aos desempregados da região.

O trabalho dos catadores ganha visibilidade devido à conscientização ambiental, sendo crescente as formas de apoio para a organização de cooperativas de trabalho.

Este apoio é dado aos catadores porque eles são um setor marginalizado da população e, em muitos casos, necessitam de políticas de caráter assistencial, para o resgate da auto-estima. São autoempregados, que possuem baixa disponibilidade de investimento e baixa qualificação profissional e que estão inseridos de maneira precária no setor informal da reciclagem.

Como visto, o setor informal está subordinado às decisões de investimento das grandes indústrias organizadas. Os catadores ocupam os espaços intersticiais da economia para realizar a coleta dos materiais recicláveis, que são comercializados através de uma cadeia de 
intermediários e sucateiros até chegar à demanda realizada pela indústria recicladora. Entretanto, devido à falta de regulamentação estatal, o que determina os índices de reciclagem, atingidos no país, é o benefício privado do reaproveitamento. É o que se chama de valorização econômica da reciclagem.

Neste cenário de valorização econômica da reciclagem e frente ao aumento da conscientização ambiental, as indústrias procuram aperfeiçoar os sistemas de coleta dos materiais descartados pósconsumo, o que pode atrair agentes com maiores disponibilidades de investimento, expulsando os pequenos negócios informais do setor da reciclagem.

Assim, os catadores são um setor marginalizado da população, que estão inseridos de maneira precária no mercado de reciclagem e devido à valorização econômica da reciclagem, que aumenta a concorrência neste setor, é necessário avaliar as formas de apoio dadas aos catadores.

Pelo estudo de caso realizado nesta pesquisa, pôde-se observar que entre os aspectos que auxiliam o desenvolvimento destas cooperativas estão: o apoio dado para a organização interna do trabalho, segundo as normas cooperativistas, e o apoio estatal através da coleta e doação dos materiais recicláveis.

Nas três cooperativas analisadas, a organização do trabalho interno e rotineiro está baseada na autogestão, na participação democrática para a tomada de decisões e na divisão igualitária dos rendimentos entre os associados.

Quanto ao apoio dado pelas prefeituras, a doação social dos materiais recicláveis é relevante para as despesas arcadas por estas cooperativas, já que o custo com a coleta e o transporte tem um peso significativo na recuperação dos materiais recicláveis.

Assim, o apoio dado para a formação destas cooperativas obtém êxito e possibilita uma maior organização do trabalho dos catadores, assim como um aumento na escala da produção. Este apoio representa 
um rico processo de aprendizagem, através do resgate da auto-estima, pelo trabalho realizado de maneira coletiva e participativa.

Quanto aos aspectos que dificultam a consolidação, nas três cooperativas analisadas pôde-se observar que existe uma grande dependência dos catadores em relação ao apoio dado por seus "mentores", especificamente na busca por inovações tecnológicas e gerenciais do próprio trabalho.

Desta forma, apesar de políticas assistenciais serem necessárias, em muitos casos, a adoção preponderante deste enfoque impede uma autonomia dos catadores em relação aos apoios oferecidos.

Além disso, pôde-se observar que o fato do Projeto Vira Lata participar de forma complementar do programa de coleta seletiva da prefeitura, tendo que realizar a coleta de materiais recicláveis com recursos próprios, nesta cooperativa ocorre uma maior interlocução com a sociedade civil, na busca pela doação de recicláveis. Esta interlocução propicia uma troca de informações que gera novas possibilidades de apoios, entre diferentes setores da sociedade.

Isto permitiu ao Projeto Vira Lata desenvolver um projeto de produção de telhas ecológicas, com papéis recicláveis, uma inovação tecnológica que agrega valor ao material coletado, modificando a inserção destes catadores no mercado de reciclagem. Assim, ao invés de serem fornecedores de materiais para as indústrias recicladoras, estes catadores têm a possibilidade de produzir bens de consumo final.

Desta forma, o estudo de caso revelou que, para a inovação do trabalho dos catadores, o apoio dado pela organização de moradores de bairro é mais dinâmico em relação ao apoio dado pelas prefeituras. Tanto a Cooperyara quanto a Associação Raio de Luz que recebem a doação de materiais recicláveis das respectivas prefeituras, apresentaram uma maior timidez na busca por inovações do próprio trabalho.

Este fato revela que, a organização dos catadores em cooperativas não modifica o caráter informal do trabalho e a inserção no mercado de 
reciclagem. Estas cooperativas continuam atuando no início da cadeia de beneficiamento dos recicláveis.

Além disso, a renda dos catadores continua vinculada ao benefício privado do reaproveitamento dos materiais recicláveis, seja quando atuam individualmente, seja quando organizados em cooperativas, seja quando incluídos em programas de coleta seletiva.

Entretanto, o apoio dado pelas prefeituras a estas cooperativas pode ser modificado. A reciclagem não deve ser encarada apenas como uma atividade de reaproveitamento dos materiais recicláveis, mas como uma das etapas para o gerenciamento dos resíduos sólidos urbanos.

Cabe lembrar que, o discurso centrado na reciclagem desconsidera o enfoque dado por algumas correntes ambientalistas do conceito dos 3 Rs, de primeiro reduzir a quantidade gerada de resíduos, depois reutilizar os materiais e, somente após estas etapas, utilizar a reciclagem.

A geração de resíduos sólidos urbanos é um problema ambiental que envolve a extração de recursos naturais e a emissão de poluição, pelo descarte de materiais inutilizados no meio ambiente. Devido à falta de uma legislação ambiental, os custos sociais provocados por esta estrutura produtiva poluente não são incorporados nas decisões privadas de produção e de consumo.

Como o gerenciamento dos resíduos sólidos urbanos é de responsabilidade da esfera municipal de governo, uma das formas utilizadas pelas prefeituras, para incluir estes custos sociais, é a tributação pela utilização dos serviços de limpeza urbana. Estes serviços incluem, por exemplo, a varrição de ruas, a manutenção de aterros, e a coleta, que pode ser feita de maneira seletiva.

A cobrança pelos serviços de limpeza urbana pode ser utilizada como uma política ambiental de minimização de resíduos à medida que a taxa cobrada seja estipulada em um nível capaz de induzir a uma mudança no comportamento dos indivíduos, que passarão a reduzir a quantidade de residuos, na fonte geradora. 
Desta forma, é utilizada uma política que mescla os instrumentos econômicos com instrumentos de comando e controle que, ao mesmo tempo, induz a uma mudança no comportamento dos indivíduos e gera um aumento na arrecadação do Estado.

Este aumento na arrecadação pode ser destinado para o estímulo da coleta seletiva, que ainda tem um papel marginal no gerenciamento dos resíduos sólidos urbanos e, também, como incentivo para as atividades de reciclagem, realizada pelos catadores.

Este incentivo às atividades dos catadores pode mudar o enfoque assistencial do apoio dado pelas prefeituras, através de uma estruturação das atividades educativas e de incubação das cooperativas. Este incentivo pode garantir uma maior autonomia dos catadores, solidificando estas iniciativas populares de economia solidária.

A autonomia destas cooperativas deve passar por uma maior integração entre as próprias cooperativas, que seria essencial para tirar os catadores dos espaços intersticiais da economia, além de proporcionar novas formas de interlocução com a sociedade civil na busca por capacitação tecnológica. A busca pelo apoio a estas cooperativas é fundamental, mas ela deve ser feita tanto dentro quanto fora do Estado.

Cabe ressaltar que, a conscientização ambiental provocou o aumento da valorização econômica da reciclagem, mas, também, possibilitou uma maior visibilidade para o trabalho dos catadores de materiais recicláveis. Estes dois efeitos geram três possibilidades para o desenvolvimento e a manutenção do trabalho realizado pelos catadores.

A primeira possibilidade é a ocorrência de uma concentração suficiente no mercado de reciclagem, que permitirá a instalação de grandes empresas organizadas, expulsando os trabalhadores autônomos e os pequenos produtores do setor informal da reciclagem.

Neste caso encontra-se a tentativa da indústria de alumínio de tornar o retorno dos materiais ao processo produtivo mais eficiente, através da instalação de máquinas de coleta de latas de aluminio em shoppings e escolas, numa relação direta com o consumidor. Esta 
logística reversa, desenvolvida pelas grandes empresas organizadas, não deixa espaço para a atuação dos catadores.

A segunda possibilidade é que as grandes empresas, na busca por mercados diferenciados, em uma sociedade, que cada vez mais, passa a valorizar posturas ecologicamente corretas e socialmente responsáveis, passem a realizar como marketing a execução de projetos de inclusão social e preservação ecológica, garantindo, desta forma, o espaço de atuação dos catadores.

Neste caso, inclui-se a iniciativa da Petrobrás de investir na produção de telhas ecológicas, via cooperativas de catadores. Esta produção das telhas utiliza um subproduto descartado no processo produtivo da Petrobrás, que é utilizado para impermeabilizar as telhas. Garante-se assim uma produção mais sustentável para os rejeitos gerados no processo produtivo, através de alternativas para a inclusão dos catadores.

A terceira possibilidade, defendida nesta pesquisa, é pela atuação das prefeituras, através da inclusão destas cooperativas nos programas municipais de coleta seletiva de lixo. Entretanto, como visto, este apoio não induz a uma maior autonomia destas cooperativas, e o incentivo à reciclagem pode ser adotado para modificar o caráter assistencial destas políticas, que têm o objetivo de gerar renda e trabalho aos catadores. Para isto cabe estimular e modificar o papel marginal da coleta seletiva no gerenciamento dos resíduos sólidos urbanos.

Atualmente, estas três alternativas ocorrem simultaneamente e o prevalecimento de uma delas dependerá das mudanças sócio-culturais e do processo de institucionalização destas práticas.

Para que as atividades das cooperativas de catadores se consolidem recomenda-se pesquisas para a inovação tecnológica no trabalho dos catadores, num maior envolvimento com a sociedade civil e uma estruturação das atividades de incubação das cooperativas. Além disso, cabe definir as formas jurídicas de inclusão das cooperativas nos programas municipais de coleta seletiva de lixo. 


\section{Referências}

[Abal] - Associação Brasileira de Alumínio. Histórico da indústria de aluminio. [on-line]. Săo Paulo: ABAL; 2003. Disponivel em <URL: http://www.abal.org.br/conheca/index.cfm?frame=conheça> $>$ [2004 ago 6]

Amazonas $\mathrm{M}$ de $\mathrm{C}$. Economia do meio ambiente: uma análise da abordagem neoclássica a partir de marcos evolucionistas e institucionalistas. Campinas; 1994. [Dissertação de mestrado - Instituto de Economia - Unicamp].

Assembléia Legislativa do Estado de São Paulo. Anteprojeto de Política Estadual de Resíduos Sólidos - Exposição e Motivos. Institui a Política Estadual de Resíduos Sólidos e dá outras providências. Palácio 9 de julho. São Paulo, 5 fev 2004.

Barueri. Lei Municipal n. 1.320, de 2 de setembro de 2002. Dispõe sobre a instituição do programa de coleta seletiva de materiais recicláveis e dá outras providências. Prefeitura Municipal de Barueri, Barueri, 2 set 2002.

BNDES. A trajetória de crescimento dos principais produtores brasileiros de papel e celulose - 1970-94. [Relatório on-line]. s.d. Disponivel em <URL: http://mww.bndes.gov.br/conhecimento/bnset/bndeset3.pdf> [2004 set 14]

BNDES. O setor de papel e celulose no Brasil e no mundo. [Relatório on-line]. $1996 . \quad$ Disponível em <URL:http://umw.bndes.gov.br/conhecimento/relato/rel52b.pdf> [2004 set 14]

BNDES. Evolução do Mercado de Alumínio. [Relatório on-line]. 1998. Disponivel em <URL: http://mww.bndes.gov.br/conhecimento/relato/rel52b.pdf> [2004 set 14]

BNDES. A década de 90 - Mercado Nacional de Papéis. [Relatório on-line]. 2000a. Disponivel em <URL: http://www.bndes.gov.br/conhecimento/publicacoes/catalogo/relato.asp\#florestais $>$ [2004 set 14]

BNDES. A década de 90 - Mercado Mundial de Papéis. [Relatório on-line]. 2000b. Disponivel em CURL: http://mww.bndes.gov.br/conhecimento/publicacoes/catalogo/relato.asp\#florestais $>$ [2004 set 14]

Brasil. Lei n. 5.764 de 16 de dezembro de 1971. Define a Política Nacional de Cooperativismo, institui o regime jurídico das sociedades cooperativas e dá outras providências. Diário Oficial da República Federativa do Brasil, Brasília, 30 out 1984. 
Brasil. Lei n. 9.637 de 15 de maio de 1998. Dispõe sobre a qualificação de entidades como organizações sociais, a criação do Programa Nacional de Publicização, a extinção dos órgãos e entidades que menciona e a absorção de suas atividades por organizações sociais, e dá outras providências. Diário Oficial da República Federativa do Brasil, Brasília, 15 mai 1998.

Bringhenti J. Coleta Seletiva de Residuos Sólidos Urbanos: Aspectos Operacionais e da Participação da População. São Paulo; 2004 [Tese de Doutorado - Faculdade de Saúde Pública - USP].

Britto JNP. Estudo da Competitividade da Indústria Brasileira Competitividade da Indústria de Alumínio. [Nota técnica on-line]. Campinas: IE/UNICAMP; $1993 . \quad$ Disponível em http://www.mct.gov.br/publi/Compet/nst alu.pdf> [2004 set 7]

Cacciamali MC. Processo de Informalidade, flexibilização das relações de trabalho e proteção social na América Latina. Cadernos PUC Economia, 2001; n 11: 111141.

Cacciamali MC. As economias informal e submersa: conceitos e distribuição de renda. In: Camargo, JR; Giambiagi, F. (orgs.) Distribuição de renda no Brasil. Rio de Janeiro: Paz e Terra; 1991. p. 121-143.

Cacciamali MC. Expansão do mercado de trabalho não regulamentado e setor informal. Estudos Econômicos, 1989; vol. 19, n. especial: 25-48.

Calderoni S. Os bilhōes perdidos no lixo. $3^{a}$. ed. São Paulo: Humanitas Editora; 1999.

Castel R. As metamorfoses da questão social - uma crônica do salário. Rio de Janeiro: Ed. Vozes; 1998.

[Cempre] Compromisso Empresarial para a Reciclagem Fichas Técnicas sobre o mercado de reciclagem para os diferentes tipos de materiais. [notas on-line]. 2003. Disponível em <URL: http://www.cempre.org.br/fichas técnicas> [2004 set 17]

[Cempre] Compromisso Empresarial para a Reciclagem Ciclosoft - 2002.

[Relatório on-line]. 2002. Disponível em <URL:

http://www.cempre.org.br/pes ciclosoft02.html> [2004 ago 15]

Chermont LS, Serôa da Motta R. Aspectos econômicos da Gestão Integrada de Resíduos Sólidos. Rio de Janeiro: IPEA Texto para Discussão nº 416; mai 1996.

Cetesb. Inventário estadual de resíduos sólidos domiciliares: relatório de 2002 - versão 2. [relatório on-line]. 2003. Disponível em <URL: http://www.cetesb.sp.gov.br> [2004 set 2] 
Conceição MM. Os empresários do lixo: um paradoxo da modernidade. Campinas: Átomo; 2003.

Contador CR. Projetos Sociais: avaliação e prática $4^{a}$. ed. ampl. São Paulo: Atlas; 2000.

Dedecca CS. Desregulação e desemprego no capitalismo avançado. São Paulo em Perspectiva. Fundação SEADE, 1996, 10 (1): 13-20.

Engels F. A Situação da Classe Trabalhadora na Inglaterra. Porto Alegre: Global Ed; 1986.

Furtado C. Formação econômica do Brasil. $7^{a}$. ed. São Paulo: Ed. Nacional; 1964.

Galbraith JK. Sociedade Afluente. São Paulo: Pioneira; 1987.

IBGE. Pesquisa Nacional de Saneamento Básico - 2000. Rio de Janeiro: IBGE; 2001.

Jakobsen K. A dimensão do trabalho informal na América Latina e no Brasil. In: Jakobsen, K; Martins, R.; Dombrowski, O. (orgs.) Mapa do trabalho informal perfil sócio-econômico dos trabalhadores informais na cidade de São Paulo. São Paulo: Editora Fundação Perseu Abramo; 2000. p. 13-18.

Jesus CM de. Quarto de Despejo - Diário de uma Favelada. $8^{\text {a }}$. ed. São Paulo: Editora Ática; 2001.

Jorge MM, Soares SJM, Naretto NA. Estudo da competitividade da indústria brasileira - competitividade da indústria de papel. [Nota técnica on-line]. 1993. Disponivel em <URL: http://www.mct.gov.br/publi/Compet/nst pap.pdf> [2004 set 7]

Kalecki M. Crescimento e ciclo econômico das economias capitalistas. São Paulo: Hucitec; 1977.

Kapp KW. Los costes Sociales de la Empresa Privada. Vilassar de Mar (Barcelona): Oikos-Tau; 1966.

Kon A. A condição da informalidade do trabalho nas atividades terciárias brasileiras. In: Cadernos PUC Economia, 2001; $n^{\circ} 11$ : 51-78.

Legaspe LR. Reciclagem: a fantasia do eco-capitalismo - um estudo sobre a reciclagem promovida no centro da cidade de São Paulo observando a economia informal e os catadores. São Paulo; 1996. [Dissertação de Mestrado - Faculdade de Geografia - USP - SP]. 
Marshall A. Princípios de Economia. São Paulo: Abril Cultural; 1982.

Marques JF, Comune AE. A teoria neoclássica e a valoração ambiental. In: Romeiro AR, Reydon BP, Leonardi ML. (orgs.). Economia do Meio Ambiente: teoria, políticas e a gestão de espaços regionais. Campinas: IE/UNICAMP; 1996.

Paiva LGD. Alternativas institucionais para a disposição final compartilhada de resíduos sólidos urbanos. São Paulo; 2002. [Dissertação de Mestrado Faculdade de Saúde Pública - USP].

Pamplona JB. A controvérsia conceitual acerca do setor informal e sua natureza político-ideológica. In: Cadernos PUC Economia, 2001a; n 11: 11-46.

Pamplona JB. Erguendo-se pelos próprios cabelos. Auto-emprego e reestruturação produtiva no Brasil. São Paulo: Germinal; 2001 b.

Pamplona JB. Auto-emprego é alternativa à crise do emprego? Folha de São Paulo, São Paulo, 2002 mai 08; Dinheiro: p. 3.

Pochmann M. O excedente de mão-de-obra no município de São Paulo. In: Jakobsen, K; Martins, R.; Dombrowski, O. (orgs.) Mapa do trabalho informal perfil sócio-econômico dos trabalhadores informais na cidade de São Paulo. São Paulo: Editora Fundação Perseu Abramo; 2000. p. 18-23.

Preste P. A tragédia dos bens comunais e suas soluções. In: Ecopolítica Internacional. São Paulo: SENAC; 2000. p. 41-59.

Romeiro AR. Desenvolvimento sustentável e mudança institucional: notas preliminares. Texto para discussão. Campinas: IE/UNICAMP Texto para discussão n. 68; abr-1999.

Romeiro AR, Salles Filho S. Dinâmica de inovações sob restrição ambiental. In: Romeiro AR, Reydon BP, Leonardi MLA (orgs.). Economia do Meio Ambiente: teoria, políticas e a gestão de espaços regionais. Campinas: IE/UNICAMP; 1996. p. 83-122.

Romeiro MC. Uma experiência de planejamento metodológico para coleta de dados no setor informal na região do $A B C$ paulista. Cadernos PUC Economia, 2001; n० 11: 79-109.

Sabbag SN. A percepção do trabalhador sobre o desemprego e a estruturação do trabalho cooperativado. São Paulo; 2003. [Tese de Doutorado - Faculdade de Saúde Pública - USP]. 
Santos B de S, Rodríguez C. Introdução: para ampliar o cânone da produção. In: Santos B de S. (org.) Produzir para viver: os caminhos da produção não capitalista. Rio de Janeiro: Civilização Brasileira; 2002. p. 23-74.

São Paulo (Município). Lei Municipal n. 13.478 de 2002. Institui a taxa de resíduos sólidos domésticos e dá outras providências. Prefeitura Municipal de São Paulo. 2002.

São Paulo (Município). Decreto Municipal n. 42. 290 de 15 de agosto de 2002. Institui o Programa Socioambiental Cooperativa de Catadores de Material Reciclável, e dá outras providências. Secretaria do Governo Municipal. São Paulo. 15 ago 2002.

Senado Federal. Comissão especial destinada a dar parecer ao projeto de lei $n$. 203 de 1991 e apensos - Política Nacional de Residuos Sólidos. Institui a Política Nacional de Resíduos Sólidos, seus principios, objetivos e instrumentos e estabelece diretrizes e normas de ordem pública e interesse social para o gerenciamento dos diferentes tipos de resíduos. Sala de Comissão. Brasilia. 2002 .

Serôa da Motta R. Indicadores ambientais no Brasil: aspectos ecológicos, de eficiência $\theta$ distributivos. Rio de Janeiro: IPEA Texto para discussão $n^{\circ} 403$; fev1996.

Serôa da Motta R, Sayago D. Propostas de instrumentos econômicos ambientais para a redução do lixo urbano e o reaproveitamento de sucata no Brasil. Rio de Janeiro: IPEA Texto para discussão nº 608; 1998.

Singer P. Introdução à Economia Solidária. São Paulo: Ed. Fundação Perseu Abramo, 2002.

Singer P, Souza AR de. (orgs.) A economia solidária no Brasil: a autogestão como resposta ao desemprego. São Paulo: Contexto, 2000.

Singer P. Desemprego e exclusão social. São Paulo em Perspectiva. Fundação SEADE, 1996, 10 (1): 3-12.

Souza PR. Emprego e renda na "pequena produção" urbana no Brasil. Estudos Econômicos, mar-1981; vol 11, n. 1: 57-82.

Tayra F. Sobre a compatibilidade entre Economia e Ecologia - Cultura, técnicas natureza na gênese da crise ambiental. São Paulo; 2003. [Tese de Doutorado - PUC - SP].

Tavares MC. Da substituição de importações ao capitalismo financeiro. $2^{a}$. ed. Rio de Janeiro: Zahar; 1973. 
Wonnacott P, Wonnacott R. Introdução à Economia. São Paulo: McGraw-Hill; 1985. 


\section{A. DADOS COLETADOS NA PESQUISA DE CAMPO}

TABELA 1 - Composição do Material Comercializado pela Cooperyara, em Kilograma, 2004.

\begin{tabular}{l|c|c|c|c|c|c|c|c}
\hline \multicolumn{1}{c|}{ Material } & Jan & Fev & Mar & Abr & Mai & Jun & TOTAL & $\%$ \\
\hline \hline TOTAL VENDIDO & 95.355 & 70.466 & 82.903 & 88.265 & 88.058 & 81.514 & 506.561 & 100,00 \\
\hline ALUMÍNIO & 254 & 272 & 404 & 546 & 424 & 376 & 2.275 & 0,45 \\
\hline PAPEL & 32.798 & 23.070 & 25.643 & 28.931 & 18.547 & 6.750 & 135.739 & 26,80 \\
\hline PAPELÃO & 15.010 & 8.770 & 14.466 & 23.238 & 24.309 & 25.069 & 110.862 & 21,89 \\
\hline PET & 6.270 & 2.480 & 7.820 & 3.939 & 4.152 & 3.940 & 28.601 & 5,65 \\
\hline PLÁSTICOS & 9.054 & 11.422 & 6.764 & 12.420 & 12.470 & 11.481 & 63.611 & 12,56 \\
\hline Plástico Duro & 6.106 & 6.653 & 5.010 & 6.807 & 7.270 & 7.100 & 38.945 & 7,69 \\
\hline Plástico Mole & 2.948 & 4.769 & 1.754 & 5.612 & 5.200 & 4.381 & 24.665 & 4,87 \\
\hline VIDROS & 11.780 & 18.352 & 15.026 & 8.202 & 17.003 & 24.429 & 94.792 & 18,71 \\
\hline METAIS & 3.050 & 6.100 & 6.210 & 5.430 & 5.580 & 5.570 & 31.940 & 6,31 \\
\hline LONGA VIDA & 14.406 & - & 6.570 & 5.560 & 5.510 & 3.900 & 35.946 & 7,10 \\
\hline VASILHAMES & 2.733 & - & - & - & - & - & 2.733 & 0,54 \\
\hline OUTROS & - & - & - & - & 63 & - & 63 & 0,01 \\
\hline FOnte: COOperyary
\end{tabular}

Fonte: Cooperyara. Elaborada pela autora.

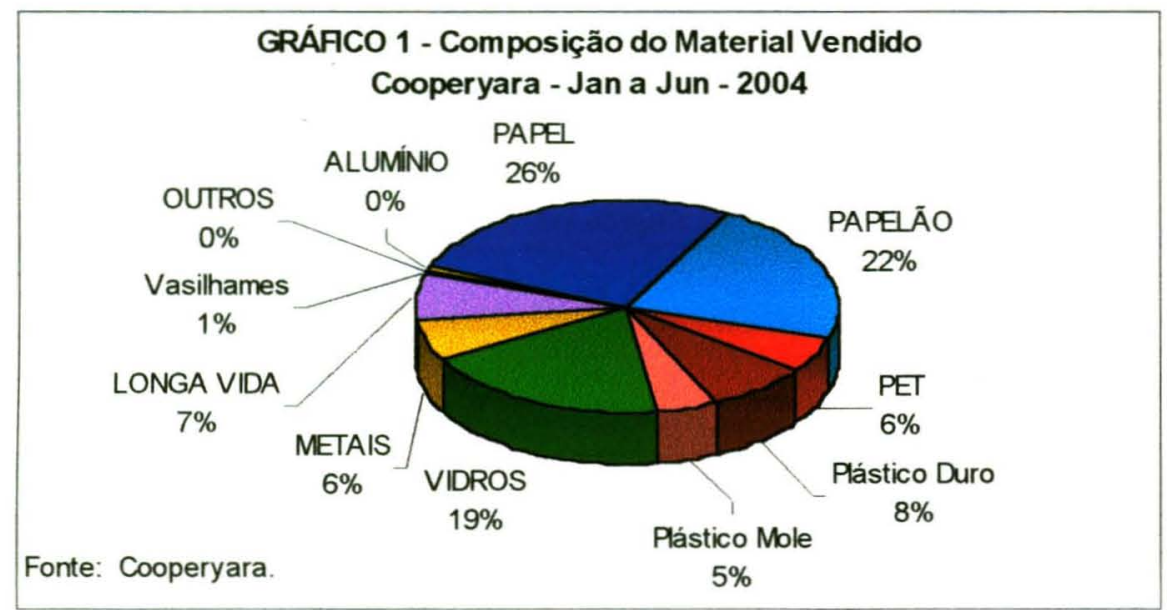


TABELA 2 - Composição do Material Comercializado pela Associação Raio de Luz, em Kilograma, 2004.

\begin{tabular}{|c|c|c|c|c|c|c|c|c|}
\hline Material & Jan & Fev & Mar & Abr & Mai & Jun & TOTAL & $\%$ \\
\hline TOTAL VENDIDO & 46.684 & 52.525 & 40.444 & 44.916 & 34.175 & 39.875 & 258.618 & 100,00 \\
\hline ALUMÍNIO & 886 & 179 & 1.003 & 115 & 116 & 219 & 2.516 & 0,97 \\
\hline PAPEL & 15.847 & 12.704 & 13.786 & 12.528 & 7.251 & 14.400 & 76.516 & 29,59 \\
\hline PAPELÃO & 3.764 & 6.850 & 7.239 & 5.220 & 6.360 & 7.040 & 36.473 & 14,10 \\
\hline PET & 3.460 & 1.681 & 1.514 & 501 & 1.910 & 1.550 & 10.616 & 4,10 \\
\hline PLÁSTICOS & 6.097 & 6.981 & 7.298 & 4.446 & 7.253 & 6.651 & 38.725 & 14,97 \\
\hline Plástico Duro & 2.425 & 4.091 & 3.699 & 1.863 & 3.426 & 2.289 & 17.792 & 6,88 \\
\hline Plástico Mole & 3.672 & 2.890 & 3.599 & 2.583 & 3.827 & 4.362 & 20.933 & 8,09 \\
\hline VIDROS & - & 9.748 & - & 10.059 & 2.570 & 1.272 & 23.649 & 9,14 \\
\hline METAIS & 11.281 & 10.776 & 9.098 & 9.958 & 7.844 & 5.958 & 54.915 & 21,23 \\
\hline LONGA VIDA & 5.054 & 2.500 & - & 2.064 & - & 2.278 & 11.896 & 4,60 \\
\hline VASILHAMES & 105 & 1.107 & 507 & 7 & 871 & 262 & 2.859 & 1,11 \\
\hline OUTROS & 190 & - & - & 18 & - & 245 & 453 & 0,18 \\
\hline
\end{tabular}

Fonte: Associação Raio de Luz. Elaborada pela autora.

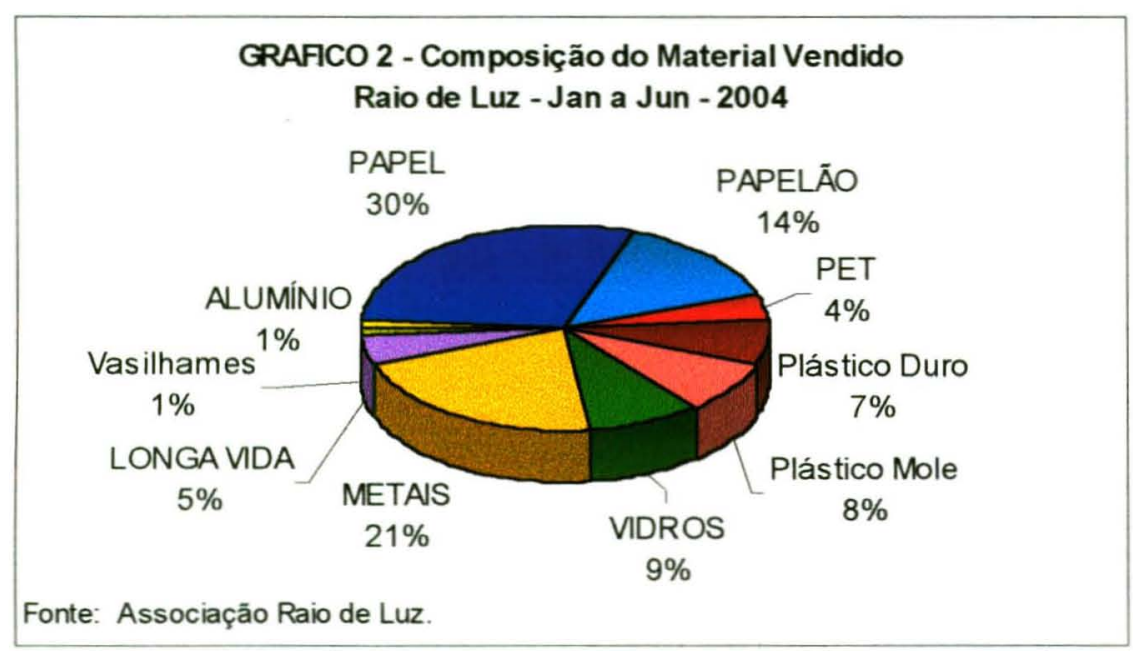


TABELA 3 - Composição do Material Comercializado pelo Projeto Vira Lata, em Kilograma, 2004.

\begin{tabular}{l|c|c|c|c|c|c|c|c}
\hline \multicolumn{1}{c|}{ Material } & Jan & Fev & Mar & Abr & Mai & Jun & TOTAL & $\%$ \\
\hline \hline TOTAL VENDIDO & 41.961 & 37.756 & 41.479 & 43.859 & 35.385 & 34.305 & 234.745 & 100,00 \\
\hline ALUMÍNIO & 202 & 166 & 230 & 154 & 102 & 127 & 981 & 0,42 \\
\hline PAPEL & 18.810 & 14.115 & 21.123 & 25.592 & 18.220 & 12.485 & 110.345 & 47,01 \\
\hline PAPELÃO & 7.090 & 8.615 & 3.956 & 3.510 & 4.833 & 5.500 & 33.504 & 14,27 \\
\hline PET & 2.670 & 771 & 1.881 & 1.040 & 1.071 & 900 & 8.333 & 3,55 \\
\hline PLÁSTICOS & 2.130 & 3.481 & 3.039 & 2.706 & 1.017 & 2.840 & 15.213 & 6,48 \\
\hline Plástico Duro & 1.270 & 2.057 & 1.873 & 1.764 & 1.017 & 1.447 & 9.428 & 4,02 \\
\hline Plástico Mole & 860 & 1.424 & 1.166 & 942 & - & 1.393 & 5.785 & 2,46 \\
\hline VIDROS & 6.870 & 8.820 & 8.700 & 6.890 & 8.340 & 9.120 & 48.740 & 20,76 \\
\hline METAIS & 2.460 & 1.788 & 2.550 & 1.497 & 1.742 & 2.637 & 12.674 & 5,40 \\
\hline LONGA VIDA & 1.729 & - & - & 2.470 & - & 696 & 4.895 & 2,09 \\
\hline OUTROS & - & - & - & - & 60 & - & 60 & 0,03 \\
\hline FOnte: PrOjeto Vir. & Lata & & - & & & & & \\
\hline
\end{tabular}

Fonte: Projeto Vira Lata. Elaborada pela autora.

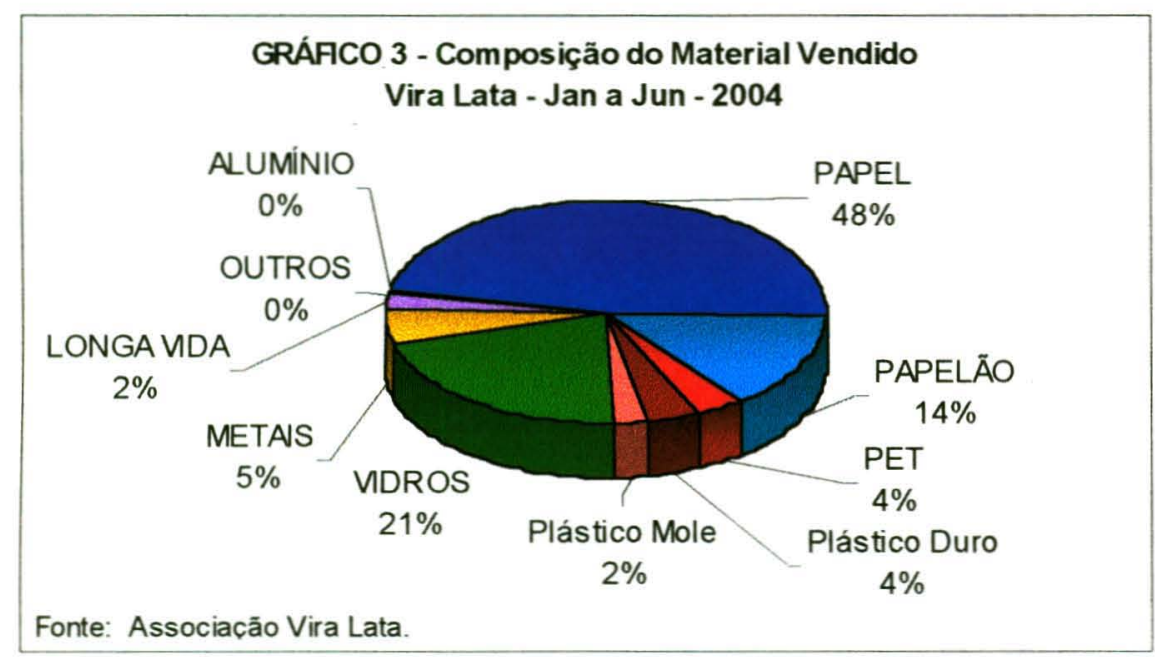


TABELA 4 - Receita Arrecadada pela Cooperyara, em Reais, 2004.

\begin{tabular}{|c|c|c|c|c|c|c|c|c|}
\hline Material & Jan & Fev & Mar & $\mathrm{Abr}$ & Mai & Jun & TOTAL & $\%$ \\
\hline $\begin{array}{c}\text { Receita } \\
\text { Arrecadada }\end{array}$ & $22.748,86$ & $16.268,88$ & $20.279,66$ & $21.036,56$ & $21.991,28$ & $20.949,37$ & $123.274,61$ & 100,00 \\
\hline ALUMÍNIO & 891,00 & 952,00 & $1.292,15$ & $1.745,90$ & $1.484,00$ & $1.314,87$ & $7.679,92$ & 6,23 \\
\hline PAPEL & $6.341,74$ & $4.299,22$ & $4.175,30$ & $4.822,17$ & $4.342,52$ & $2.557,00$ & $26.537,95$ & 21,53 \\
\hline PAPELÃO & $2.701,80$ & $1.499,86$ & $2.247,21$ & $3.748,98$ & $3.990,50$ & $4.011,00$ & $18.199,35$ & 14,76 \\
\hline PET & $4.702,50$ & $1.860,00$ & $6.116,00$ & $2.954,50$ & $3.114,00$ & $3.546,00$ & $22.293,00$ & 18,08 \\
\hline PLÁSTICOS & $3.945,12$ & $4.957,80$ & $2.963,00$ & $5.048,02$ & $5.432,22$ & $5.641,50$ & $27.987,66$ & 22,70 \\
\hline Plástico Duro & $2.564,52$ & $2.791,80$ & $2.103,00$ & $2.880,02$ & $3.027,00$ & $3.730,00$ & $17.096,34$ & 13,87 \\
\hline Plástico Mole & $1.380,60$ & $2.166,00$ & 860,00 & $2.168,00$ & $2.405,22$ & $1.911,50$ & $10.891,32$ & 8,84 \\
\hline VIDROS & 737,70 & $1.148,00$ & 949,00 & 518,00 & $1.206,04$ & $1.437,00$ & $5.995,74$ & 4,86 \\
\hline METAIS & 762,50 & $1.552,00$ & $1.552,00$ & $1.357,00$ & $1.546,00$ & $1.610,00$ & $8.379,50$ & 6,80 \\
\hline LONGA VIDA & $2.160,90$ & - & 985,00 & 834,00 & 826,00 & 585,00 & $5.390,90$ & 4,37 \\
\hline Vasilhames & 505,60 & - & - & 8,00 & - & 247,00 & 760,60 & 0,62 \\
\hline OUTROS & - & - & - & - & 50,00 & - & 50,00 & 0,04 \\
\hline
\end{tabular}

Fonte: Cooperyara. Elaborada pela autora.

TABELA 5 - Receita Arrecada pela Associação Raio de Luz, em Reais, 2004.

\begin{tabular}{l|c|c|c|c|c|c|c|c}
\hline \hline Material & Jan & Fev & Mar & Abr & Mai & Jun & TOTAL & $\%$ \\
\hline $\begin{array}{c}\text { Receita } \\
\text { Arrecadada }\end{array}$ & $15.195,85$ & $11.933,70$ & $14.148,37$ & $9.581,73$ & $11.189,84$ & $11,230,95$ & $73.280,43$ & 100,00 \\
\hline ALUMINIO & $2.745,60$ & 575,10 & $3.725,00$ & 415,85 & 450,25 & 816,90 & $8.728,70$ & 11,91 \\
\hline PAPEL & $3.236,45$ & $2.191,95$ & $2.529,80$ & $2.324,70$ & $1.758,80$ & $2.145,40$ & $14.187,09$ & 19,36 \\
\hline PAPELĀO & 752,80 & $1.342,70$ & $1.499,40$ & $1.096,20$ & $1.399,20$ & $1.619,20$ & $7.709,50$ & 10,52 \\
\hline PET & $2.476,60$ & $1.254,30$ & $1.126,70$ & 402,80 & $1.542,30$ & $1.288,00$ & $8.090,70$ & 11,04 \\
\hline PLÁSTICOS & $2.277,90$ & $2.579,77$ & $2.883,63$ & $1.644,80$ & $3.013,40$ & $2.643,85$ & $15.043,35$ & 20,53 \\
\hline Plástico Duro & $1.129,05$ & $1.730,47$ & $1.736,13$ & 863,40 & $1.814,50$ & $1.183,20$ & $8.456,75$ & 11,54 \\
\hline PIástico Mole & $1.148,85$ & 849,30 & $1.147,50$ & 781,40 & $1.198,90$ & $1.460,65$ & $6.586,60$ & 8,99 \\
\hline VIDROS & - & 580,88 & - & 493,99 & 282,70 & 140,00 & $1.497,57$ & 2,04 \\
\hline METAIS & $3.061,40$ & $2.918,10$ & $2.279,74$ & $2.810,29$ & $2.656,69$ & $2.005,20$ & $15.731,42$ & 21,47 \\
\hline LONGA VIDA & 567,10 & 375,00 & - & 309,60 & - & 341,70 & $1.593,40$ & 2,17 \\
\hline VASILHAMES & 21,00 & 115,90 & 104,10 & 3,50 & 86,50 & 55,70 & 386,70 & 0,53 \\
\hline OUTROS & 57,00 & - & - & 80,00 & - & 175,00 & 312,00 & 0,43 \\
\hline
\end{tabular}

Fonte: Associação Raio de Luz. Elaborada pela autora. 
TABELA 6 - Receita Arrecada pelo Projeto Vira Lata, em Reais, 2004.

\begin{tabular}{c|c|c|c|c|c|c|c|c}
\hline Material & Jan & Fev & Mar & Abr & Mai & Jun & TOTAL & $\%$ \\
\hline $\begin{array}{c}\text { Receita } \\
\text { Arrecadada }\end{array}$ & $13.492,85$ & $12.279,92$ & $14.530,21$ & $16.728,23$ & $13.569,89$ & $14.534,65$ & $85.135,75$ & 100,00 \\
\hline ALUMÍNIO & 673,90 & 557,10 & 778,03 & 551,66 & 382,70 & 458,00 & $3.401,39$ & 4,00 \\
\hline PAPEL & $4.848,20$ & $3.189,20$ & $4.561,30$ & $6.005,47$ & $4.584,70$ & $3.134,70$ & $26.323,57$ & 30,92 \\
\hline PAPELÃO & $1.429,70$ & $1.267,42$ & 895,96 & 864,80 & $1.269,43$ & $1.320,00$ & $7.047,31$ & 8,28 \\
\hline PET & $2.055,90$ & 688,27 & $1.489,17$ & 884,00 & 935,00 & 828,00 & $6.880,34$ & 8,08 \\
\hline PLÁSTICOS & $1.400,00$ & $1.874,40$ & $1.482,85$ & $1.419,00$ & 523,35 & $1.706,45$ & $8.406,05$ & 9,87 \\
\hline Plástico Duro & $1.080,00$ & 880,00 & $1.133,05$ & $1.136,40$ & 523,35 & $1.288,55$ & $6.041,35$ & 7,10 \\
\hline Plástico Mole & 320,00 & 994,40 & 349,80 & 282,60 & - & 417,90 & $2.364,70$ & 2,78 \\
\hline VIDROS & 941,55 & $1.222,95$ & $1.175,25$ & $1.021,50$ & $1.119,90$ & $1.161,45$ & $6.642,60$ & 7,80 \\
\hline METAIS & 520,60 & 460,74 & 788,95 & 574,10 & 779,70 & 862,20 & $3.986,29$ & 4,68 \\
\hline LONGA VIDA & 380,00 & - & - & 370,50 & - & 111,36 & 861,86 & 1,01 \\
\hline OUTROS & - & 30,00 & - & 70,00 & 24,00 & - & 124,00 & 0,15 \\
\hline $\begin{array}{c}\text { Centr. Triagem } \\
\text { Leopoldina }\end{array}$ & $1.243,00$ & $1.440,00$ & $1.455,00$ & $2.612,20$ & $1.440,00$ & $2.041,22$ & $10.231,42$ & 12,02 \\
\hline $\begin{array}{c}\text { Centr. Triagem } \\
\text { Pinheiros }\end{array}$ & - & $1.549,84$ & $1.903,70$ & $2.355,00$ & $2.511,11$ & $2.911,27$ & $11.230,92$ & 13,19 \\
\hline
\end{tabular}

Fonte: Projeto Vira Lata. Elaborada pela autora.

TABELA 7 - Percentual da Receita da Receita Arrecadada pelo Projeto Vira Lata na sede e nas Centrais de Triagem, do Programa da Prefeitura de São Paulo, 2004.

\begin{tabular}{c|c|c|c|c|c|c|c}
\hline Material & Jan & Fev & Mar & Abr & Mai & Jun & TOTAL \\
\hline $\begin{array}{c}\text { Receita } \\
\text { Arrecadada }\end{array}$ & 100,00 & 100,00 & 100,00 & 100,00 & 100,00 & 100,00 & 100,00 \\
\hline $\begin{array}{c}\text { Sede } \\
\text { Vira Lata }\end{array}$ & 90,79 & 75,65 & 76,88 & 70,31 & 70,88 & 65,93 & 74,79 \\
\hline $\begin{array}{c}\text { Centr. Triagem } \\
\text { Leopoldina }\end{array}$ & 9,21 & 11,73 & 10,01 & 15,62 & 10,61 & 14,04 & 12,02 \\
\hline $\begin{array}{c}\text { Centr. Triagem } \\
\text { Pinheiros }\end{array}$ & - & 12,62 & 13,10 & 14,08 & 18,51 & 20,03 & 13,19 \\
\hline Fonte. Projeto
\end{tabular}

Fonte: Projeto Vira Lata. Elaborada pela autora. 
TABELA 8 - Despesas* Realizadas por mês e média mensal, em Reais, 2004.

\begin{tabular}{l|c|c|c|c|c|c|c|c}
\hline $\begin{array}{l}\text { Organizaçőes } \\
\text { de Catadores }\end{array}$ & Janeiro & Fevereiro & Março & Abril & Maio & Junho & TOTAL & $\begin{array}{c}\text { Média } \\
\text { Mensal }\end{array}$ \\
\hline \hline Cooperyara** & $\ldots$ & $\ldots$ & $\ldots$ & $\ldots$ & $\ldots$ & $\ldots$ & $\ldots$ & 880,00 \\
\hline Raio de Luz & $\ldots$ & 695,06 & 618,24 & 624,99 & 923,02 & $\ldots$ & $2.861,31$ & 715,33 \\
\hline Vira Lata & $4.320,92$ & $3.213,27$ & $3.313,07$ & $3.957,70$ & $3.811,98$ & $2.712,44$ & $21.329,38$ & $3.554,90$ \\
\hline
\end{tabular}

Fonte: Elaborada pela autora.

* Excluídas as retiradas dos cooperadores, inclusive pagamentos em período de licença e eventuais bônus.

**Dado estimado pelos catadores.

TABELA 9 - Estimativa* das Despesas Realizadas por mês na Cooperyara, em Reais, de janeiro a junho de 2004.

\begin{tabular}{l|c}
\hline \multicolumn{1}{c|}{ Item } & $\begin{array}{c}\text { Valor } \\
\text { Estimado }\end{array}$ \\
\hline \hline Telefone & 500,00 \\
\hline Mercado e Diversas & 150,00 \\
\hline Transporte & 60,00 \\
\hline Fita de prensa & 170,00 \\
\hline TOTAL & 880,00 \\
\hline
\end{tabular}

Fonte: Cooperyara. Elaborada pela autora.

* Estes dados foram estimados pelos catadores, devido à não contabilização das despesas pela Cooperyara.

TABELA 10 - Despesas Realizadas na Associação Raio de Luz, por mês e média mensal, em Reais, 2004.

\begin{tabular}{l|c|c|c|c|c|c|c}
\hline \hline \multicolumn{1}{c|}{ Item } & Janeiro & Fevereiro & Março & Abril & Maio & Junho & $\begin{array}{c}\text { Média } \\
\text { Mensal }\end{array}$ \\
\hline \hline Telefone & $\ldots$ & $\ldots$ & 324,66 & 435,49 & 696,53 & $\ldots$ & 485,56 \\
\hline Mercado e Diversas & $\ldots$ & $\ldots$ & 220,73 & 87,75 & 203,49 & $\ldots$ & 170,66 \\
\hline Transporte & $\ldots$ & $\ldots$ & 42,75 & 41,75 & 23,00 & $\ldots$ & 35,83 \\
\hline Fita de prensa & $\ldots$ & $\ldots$ & 30,00 & 60,00 & - & $\ldots$ & 30,00 \\
\hline TOTAL & $\ldots$ & 695,06 & 618,14 & 624,99 & 923,02 & $\ldots$ & $\mathbf{7 1 5 , 3 0}$ \\
\hline
\end{tabular}

Fonte: Associação Raio de Luz.

(...) Dado não disponível. 
TABELA 11 - Despesas Realizadas no Projeto Vira Lata, por mês e média mensal, em Reais, 2004.

\begin{tabular}{l|c|c|c|c|c|c|c}
\hline \hline \multicolumn{1}{c|}{ Item } & Janeiro & Fevereiro & Março & Abril & Maio & Junho & $\begin{array}{c}\text { Média } \\
\text { Mensal }\end{array}$ \\
\hline \hline Telefone & 339,05 & - & 265,36 & - & 83,66 & - & 114,68 \\
\hline Mercado e Diversas & $1.727,53$ & 843,17 & 446,32 & 297,41 & 772,25 & 787,52 & 812,37 \\
\hline Transporte & - & - & - & 211,60 & - & - & 35,27 \\
\hline Fita de prensa & - & - & 205,00 & 113,22 & - & - & 53,04 \\
\hline Combustivel & $2.012,14$ & $1.563,10$ & $1.248,39$ & $2.081,57$ & $1.687,45$ & $1.724,92$ & $1.719,60$ \\
\hline Desp. diversas velculos & 242,20 & 807,00 & $1.148,00$ & $1.253,90$ & $1.268,62$ & 200,00 & 819,95 \\
\hline TOTAL & $4.320,92$ & $3.213,27$ & $3.313,07$ & $3.957,70$ & $3.811,98$ & $2.712,44$ & $3.554,90$ \\
\hline
\end{tabular}

Fonte: Projeto Vira Lata. Elaborada pela autora.

TABELA 12 - Preço de Venda dos Materiais na Cooperyara, por Kilograma, em Reais, 2004.

\begin{tabular}{l|c|c|c|c|c|c|c}
\hline \multicolumn{1}{c|}{ Material } & Jan & Fev & Mar & Abr & Mai & Jun & TOTAL \\
\hline \hline ALUMINIO & 3,51 & 3,50 & 3,20 & 3,20 & 3,50 & 3,50 & 3,38 \\
\hline PAPEL & 0,19 & 0,19 & 0,16 & 0,17 & 0,23 & 0,38 & 0,31 \\
\hline PAPELAO & 0,18 & 0,17 & 0,16 & 0,16 & 0,16 & 0,16 & 0,16 \\
\hline PET & 0,75 & 0,75 & 0,78 & 0,75 & 0,75 & 0,90 & 0,78 \\
\hline PLASTICOS & 0,44 & 0,43 & 0,44 & 0,41 & 0,44 & 0,49 & 0,44 \\
\hline Plástico Duro & 0,42 & 0,42 & 0,42 & 0,42 & 0,42 & 0,53 & 0,44 \\
\hline Plástico Mole & 0,47 & 0,45 & 0,49 & 0,39 & 0,46 & 0,44 & 0,44 \\
\hline VIDROS & 0,06 & 0,06 & 0,06 & 0,06 & 0,07 & 0,06 & 0,06 \\
\hline METAIS & 0,25 & 0,25 & 0,25 & 0,25 & 0,28 & 0,29 & 0,26 \\
\hline LONGA VIDA & 0,15 & & 0,15 & 0,15 & 0,15 & 0,15 & 0,15 \\
\hline VASILHAMES & 0,18 & & & & & & 0,18 \\
\hline OUTROS & & & & & 0,80 & & 0,80 \\
\hline FOnT COOperyas
\end{tabular}

Fonte: Cooperyara. Elaborada pela autora. 
TABELA 13 - Preço de Venda dos Materiais na Associação Raio de Luz, por Kilograma, em Reais, 2004.

\begin{tabular}{l|c|c|c|c|c|c|c}
\hline \hline \multicolumn{1}{c|}{ Material } & Jan & Fev & Mar & Abr & Mai & Jun & TOTAL \\
\hline \hline ALUMINIO & 3,10 & 3,22 & 3,72 & 3,62 & 3,90 & 3,74 & 3,47 \\
\hline PAPEL & 0,20 & 0,17 & 0,18 & 0,19 & 0,24 & 0,15 & 0,19 \\
\hline PAPELAO & 0,20 & 0,20 & 0,21 & 0,21 & 0,22 & 0,23 & 0,21 \\
\hline PET & 0,72 & 0,75 & 0,74 & 0,80 & 0,81 & 0,83 & 0,76 \\
\hline PLASTICOS & 0,37 & 0,37 & 0,40 & 0,37 & 0,42 & 0,40 & 0,39 \\
\hline Plástico Duro & 0,47 & 0,42 & 0,47 & 0,46 & 0,53 & 0,52 & 0,48 \\
\hline Plástico Mole & 0,31 & 0,29 & 0,32 & 0,30 & 0,31 & 0,33 & 0,31 \\
\hline VIDROS & & 0,06 & & 0,05 & 0,11 & 0,11 & 0,06 \\
\hline METAIS & 0,27 & 0,27 & 0,25 & 0,28 & 0,34 & 0,34 & 0,29 \\
\hline LONGA VIDA & 0,11 & 0,15 & & 0,15 & & 0,15 & 0,13 \\
\hline VASILHAMES & 0,20 & 0,10 & 0,21 & 0,50 & 0,10 & 0,21 & 0,14 \\
\hline OUTROS & 0,30 & & & 4,44 & & 0,71 & 0,69 \\
\hline
\end{tabular}

Fonte: Associação Raio de Luz.

TABELA 14 - Preço de Venda dos Materiais no Projeto Vira Lata, por Kilograma, em Reais, 2004.

\begin{tabular}{l|c|c|c|c|c|c|c}
\hline \multicolumn{1}{c|}{ Material } & Jan & Fev & Mar & Abr & Mai & Jun & TOTAL \\
\hline \hline ALUMINIO & 3,34 & 3,36 & 3,38 & 3,59 & 3,75 & 3,61 & 3,47 \\
\hline PAPEL & 0,26 & 0,23 & 0,22 & 0,23 & 0,25 & 0,25 & 0,24 \\
\hline PAPELAO & 0,20 & 0,15 & 0,23 & 0,25 & 0,26 & 0,24 & 0,21 \\
\hline PET & 0,77 & 0,89 & 0,79 & 0,85 & 0,87 & 0,92 & 0,83 \\
\hline PLASTICOS & 0,66 & 0,54 & 0,49 & 0,52 & 0,51 & 0,60 & 0,55 \\
\hline Plástico Duro & 0,85 & 0,43 & 0,60 & 0,64 & 0,51 & 0,89 & 0,64 \\
\hline Plástico Mole & 0,37 & 0,70 & 0,30 & 0,30 & & 0,30 & 0,41 \\
\hline VIDROS & 0,14 & 0,14 & 0,14 & 0,15 & 0,13 & 0,13 & 0,14 \\
\hline METAIS & 0,21 & 0,26 & 0,31 & & 0,45 & 0,33 & 0,31 \\
\hline LONGA VIDA & 0,22 & & & 0,15 & & 0,16 & 0,18 \\
\hline OUTROS & & & & & 0,40 & & 0,40 \\
\hline FOnte: PrOjeto
\end{tabular}

Fonte: Projeto Vira Lata. Elaborada pela autora. 


\section{B. QUESTIONÁRIO APLICADO NA PESQUISA DE CAMPO}

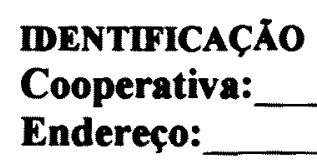

Fax:

E-mail:

Horário de Expediente: ___ às _ _

RESPONSÁVEIS PELAS INFORMAÇOEES FORNECIDAS

Nome:

Cargo:

Data da Entrevista:

Nome:

Cargo:

Data da Entrevista:

\section{ADMINISTRAÇÃO E OPERAÇÃO}

$1.1-$ Em que ano foi fundada a cooperativa?

1.2 - Como surgiu a iniciativa para a criação da cooperativa?

1.3 - Qual o número de funcionários administrativos?

1.4 - Qual o número de cooperados?

1.5 - Qual o número de associados?

1.6 - Qual o número de voluntários na cooperativa?

1.7 - Qual o número de funcionários cedidos por outras instituições?

1.8 - Quais as instalações que a cooperativa possui? 
1.9 - O espaço utilizado pela cooperativa é:

Próprio

Alugado

Contrato de concessão de uso com a Prefeitura.

Outros. Quais?

1.10 - A cooperativa possui:

- Veículos para transporte do material coletado $\square$ Sim $\square$ Não Quantos?

- Computadores

$\square \operatorname{Sim} \square$ Não Quantos?

- Internet

$\square \operatorname{sim} \square$ Não Quantos?

- Telefones

$\square \operatorname{Sim} \square$ Não Quantos?

- Fax

$\square \operatorname{Sim} \square$ Não Quantos?

- Outros

1.11 - Quais os equipamentos que a cooperativa possui?

$\square$ Prensas

Enfardadeiras

Esteira para triagem

Outros

Quais?

- Descreva como a Cooperativa adquiriu estes equipamentos

1.12 - Descreva as parcerias (participação de organizações da sociedade civil, ONG's, administração pública e empresas privadas) nas atividades das cooperativas. 
1.13- Quais são as origens do material arrecadado pela cooperativa?

Material coletado pelos cooperados

Doaçðes

Implantação de coleta seletiva realizada pela cooperativa, em lugares especificos.

Programa de coleta seletiva, realizado pela prefeitura.

Material coletado por outros catadores que não possuem vínculo com a cooperativa.

$\square$ Outros

Quais?

2. Organização Jurídica

2.1- A cooperativa possui estatuto?

$\square$ SIM $\square$ NÃO

2.2- Há quanto tempo?

2.3- A cooperativa realiza reuniões ou assembléias com os cooperados?

$\square$ SIM $\square$ NÃO

2.4- Com que freqüência?

2.5 - Qual o número, em média, de cooperados que participam dessas reuniões?

2.6 - Como são tomadas as decisões na cooperativa? 


\section{Organização financeira}

3.1- Quais as fontes de receita para a cooperativa?

$\square$ Venda de Material Reciclável

$\square$ Venda de Bens de Consumo (agenda, artesanatos, etc.)

$\square$ Prestação de Serviços Quais?

$\square$ Outros Quais?

3.2 - Existência de financiamentos?

$\square$ SIM $\square$ NÃO

3.3- Financiamentos de quais instituições? Especifique.

$\square$ ONG's

Administração Pública

$\square$ Empresas Privadas

$\square$ outras

3.4- Existência de doações?

$\square$ SIM $\square$ NÃO

3.5- Quais instituições?

\section{ONG's}

Administração Pública

Empresas Privadas

Outras

3.6- A cooperativa recebe outros tipos de apoio?

SIM $\square$ NÃO

Especifique:

3.7- A cooperativa possui uma conta bancária?

SIM

$\square$ NÃO 
3.8 - Os cooperados recebem rendimentos fixos mensalmente?

$\square$ SIM $\square$ NÃO

3.8- Existe algum fundo de aplicação para os recursos destinados à execução das atividades da cooperativa? Por exemplo, o FATES?

SIM $\square$ NÃO

3.9 - Qual a porcentagem da receita dos cooperados é destinada para este Fundo?

3.10 - Os cooperados contribuem com o INSS?

SIM $\square$ NÃO

4. Inserção Econômica

4.1- A cooperativa executa a coleta de todos os tipos de materiais recicláveis?

$\square$ SIM $\square$ NÃO

Quais os materiais que não são recolhidos?

4.2- Quantos compradores, em média, a cooperativa possui para os materiais coletados?

4.3- Possui compradores para todos os tipos de materiais coletados?

SIM $\square$ NÃO

Especifique:

4.4- Realiza venda de materiais diretamente às indústrias de reciclagem?

SIM $\square$ NÃO

Especifique (o material e a indústria ) :

B.5 
4.5- A cooperativa realiza alguma atividade para agregar valor ao material, por exemplo, triturar, prensar, lavar, granular. Especifique (por material):

4.6- Realiza venda a sucateiros e a intermediários?

$\square$ SIM $\square$ NÃO

Especifique (os materiais )

4.7- A cooperativa realiza algum processo de transformação no material coletado, transformando-o em bem de consumo, com venda direta ao consumidor, como, por exemplo, em feiras de reciclagem?

$\square$ SIM $\square$ NÃO

Especifique:

\section{Organização Assistencial e Social}

5.1- A cooperativa realiza projetos assistenciais para atendimento aos cooperados?

$\square$ SIM $\square$ NÃO

Quais:

5.2- Qual o número de pessoas atendidas em cada projeto?

5.3- Realiza programas que envolva a participação popular, como a implantação de programas de coleta seletiva em feiras, escolas, bairros e condomínios?

SIM $\square$ NÃO

Quais:

5.4- O material coletado por estes programas é doado ou vendido para a cooperativa? 
5.5 - Qual o percentual deste material em relação ao montante arrecadado pela cooperativa?

6.0 - Comente as principais dificuldades, na sua opinião, encontradas pela cooperativa na consolidação das atividades dos catadores de lixo. 